Universidade de SÃo PaUlo

ESCOLA DE ENFERMAGEM

Márcia Maria Benevenuto de Oliveira

\title{
A Representação Social de Mulheres DoAdoras de LeITE Humano
}


Márcia Maria Benevenuto de Oliveira

\section{A Representação Social de Mulheres DoAdoras de LeITE Humano}

Tese apresentada ao Programa Interunidades de Doutoramento em Enfermagem da Escola de Enfermagem da Universidade de São Paulo e Escola de Enfermagem de Ribeirão Preto da Universidade de São Paulo para obtenção do título de doutor em Enfermagem.

ORIENTADOR:

PROFa. DR . ISÍLIA APARECIDA SILVA

SÃo PAULO - SP

2016 
AUTORIZO A REPRODUÇÃO E DIVULGAÇÃO TOTAL OU PARCIAL DESTE TRABALHO, POR QUALQUER MEIO CONVENCIONAL OU ELETRÔNICO, PARA FINS DE ESTUDO E PESQUISA, DESDE QUE CITADA A FONTE.

Assinatura:

Data: 1

\section{Catalogação elaborada pela Divisão de Processos Técnicos da Biblioteca Central da Universidade Estadual de Londrina}

\section{Dados Internacionais de Catalogação-na-Publicação (CIP)}

O48r Oliveira, Márcia Maria Benevenuto de.

A representação social de mulheres doadoras de leite humano / Márcia Maria Benevenuto de Oliveira. - São Paulo, 2016.

144 p. : il.

Orientador: Isília Aparecida Silva.

Tese (Doutor em Enfermagem) - Universidade de São Paulo, Escola de Enfermagem de Ribeirão Preto, Programa Interunidades de Doutoramento em Enfermagem, 2016.

Inclui bibliografia.

1. Bancos de leite humano - Teses. 2. Leite humano - Teses. 3. Aleitamento materno - Teses. I. Silva, Isília Aparecida. II. Universidade de São Paulo. Escola de Enfermagem de Ribeirão Preto. Programa Interunidades de Doutoramento em Enfermagem. III. Título.

CDU 613.287.8 


\section{Márcia Maria BeneVenuto de Oliveira}

\section{A Representação Social de Mulheres DoAdoras de LeITE Humano}

Tese apresentada ao Programa Interunidades de Doutoramento em Enfermagem da Escola de Enfermagem da Universidade de São Paulo e Escola de Enfermagem de Ribeirão Preto da Universidade de São Paulo para obtenção do título de doutor em Enfermagem.

APROVADO EM: ___

\section{BANCA EXAMINADORA}

Prof. Dr.

Instituição:

Assinatura

Prof. Dr.

Instituição:

Assinatura

Prof. Dr.

Instituição:

Assinatura

Prof. Dr.

Instituição:

Assinatura

Prof. Dr.

Instituição:

Assinatura 


\section{Dedicatópia}

Ao Lucas, Tatiana e Gregório, meus filhos, meus tesouros, razão da minha vida

A Kátia, Gustavo e Virgínia, filthos que vieram depois e também se tornaram meus. Amo vocês e agradeço a Deus todos os dias por vocês existirem.

Ao João,

meu neto querido, que chegou para tornar nossa vida mais alegre. Que Deus esteja ao seu lado para iluminar você todos os dias da sua vida.

Ao Nelson, meu marido e companheiro de tantos anos: o mérito desta vitória também é seu. 
Agradecimento Especial

A Hyolanda e Adolfo, meus pais, com muitas saudades, agradeço todo o amor e dedicação que tiveram por mim ao longo de suas vidas. 


\title{
Agradecimentos
}

\author{
A Deus, \\ meu rochedo e fortaleza, sempre presente \\ em todas as horas da minha vida. \\ A Ora. Isilia Aparecida Silva, \\ minha orientadora, pela competência e sabedoria \\ com que me conduziu ao longo desta jornada.
}

Ao amigo e mestre João Aprígio, pelo seu jeito de valorizar cada um que está a seu lado e pela oportunidade a mim concedida de compartilhar a nossa tecnologia com o mundo e aprender tanto.

A minha familia, em especial ao meu irmão Marcos, com quem sempre posso contar.

Aos meus sobrinhos Marquinhos, Isabela, Énio, Josiê e Fábio e aos que já vieram depois de vocês, seus filthos e seus companheiros, pela alegria de compartithar as suas vidas.

\section{A Maria do Carmo,} minha irmã de coração, por poder trithar grande parte da minha jornada de vida ao seu lado, me presenteando com sua sabedoria, seus conhecimentos e seu tempo tão precioso, e por me fazer acreditar que eu seria capaz.

A Dalete,

minha amiga de tantos anos, pela força transmitida nos momentos de incerteza, pela disponibilidade em qualquer que fosse - momento e por acreditar que este trabaltho seria possivel. 
A Mauren, minha querida amiga, que sempre se esmera em fazer com que a minha vida fique mais leve, com gestos simples e tão eficazes. Isso vai além da amizade!

A Mara e Soninha, meus grandes apoios nesta fase, por estarem disponiveis quando eu mais precisei.

A Marly, Ana, Rachel, Maria, Ritinha, Marsilene, Letícia, Conceição, Eranciele e Rafael, minha querida equipe do Banco de Leite Humano do Hospital Universitário de Londrina, por todo apoio e por manterem o setor em harmonia.

A Sitvia Cordiolli, muito obrigada pelo apoio imrestrito tanto às minhas necessidades de tempo dedicado ao doutorado, como também à equipe do Banco de Leite, sempre.

As amigas do grupo do aleitamento materno, Andreza, Valentina, Lilian, Sarah, Kátia, Edilaine, Ana Olympia, Mauren e Dalete, por esses longos anos de convívio amoroso na busca da valorização da amamentação.

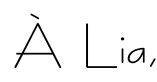
amiga que sempre está disposta a mostrar o que a vida tem de bom, pela amizade irrestrita na jornada de nossas vidas.

Ao meu grupo UUFEM i971, que, de uma maneira muito especial, me apoia em prontidão de oração. Que Deus as recompense! 


\section{Ao professor Dalmas,} pela tranquilidade transmitida e prestimosidade incondicional nos momentos que precisei.

\section{A Mirtha Diesel,}

minha querida amiga e professora de espantiol, sempre com uma palavra de ânimo nos momentos em que tudo parece desabar, por não medir esforços para a elaboração do resumen.

$$
\text { A Mariana Haddad, }
$$

querida amiga doutora em Enfermagem, cuja trajetória de vida tanto admiro, por ainda ter arranjado tempo, em meio a uma longa jornada de trabalho, para elaborar com primor o abstract.

$$
\text { A Edna Picelli, }
$$

pelo profissionalismo, amizade, carinho e, principalmente, fazer que até o maior problema se transformasse em riso.

\section{A Clarice Spoladore,} pelas preciosas orientações e correções do texto, além de se colocar disponivel em momentos tumultuados. Já me considero sua amiga!

As bibliotecárias Vilma, Cidinha, Malu e Cidinha Mariani, por realizarem seu trabaltho com tanta eficiência e dedicação e nunca se estressarem nem me afobarem por causa das minhas constantes solicitações. Vocês me deixaram em paz com seu trabalho primoroso.

$$
\text { As colegas do Departamento de Enfermagem da }
$$
Universidade Estadual de Londrina pelo apoio recebido, em especial à Mauren, Elávia, Edilaine, Sarah, Rosângela e Adriana, parceiras da Saúde da Criança. 


\section{A Diretora Superintendente e Diretora de Enfermagem do Hospital Universitário de Londrina, pelo incentivo e apoio na jornada que empreendi.}

Aos colegas da Diretoria de Enfermagem do Hospital Universitário de Londrina, pelo apoio e confiança na concretização desta etapa de minha vida.

Meu carinho e gratidão eterna à Universidade Estadual de Londrina - de certa forma, minha casa desde 1974.

Aos professores e funcionários do Programa Interunidades de Doutoramento em Enfermagem da Escola de Enfermagem da Universidade de São Paulo e Escola de Enfermagem de Ribeirão Preto da Universidade de São Paulo, pela competência, respeito e consideração.

A tia Zilda, dona Eva, dona lda e dona Rosa
pela torcida, carinho e oraçōes.

A Débora, Stella e Paloma pela presteza em sempre colaborar. Vocês são especiais.

A todas as mulheres doadoras que participaram desta pesquisa e que expuseram suas representações a respeito da doação, o meu mais profundo agradecimento. Este singelo "obrigada" se estende a todas as mutheres que se dispõem a compartithar, a ajudar outra criança além de seu filho com o leite da sua doação. Vocês são o máximo!

A todos os "anjos" que passaram na minha vida nesta trajetória e que, pela impossibilidade de nominar a todos, peço a Deus, que tudo pode, recompensá-los com muitas bênçãos. 


\section{Senbor,}

não é soberbo o meu coração, nem altivo o meu olbar; não ando à procura de grandes coisas, nem de coisas marabilhosas demais para mim.

Pelo contrário, fiz calar e sossegar a minba alma; como a criança desmamada se aquieta nos braços de sua mãe, como essa criança é a minha alma para comigo.

(SALMO 131:1-2) 
OLIVEIRA, M. M. B. DE. A representação social de mulheres doadoras de leite humano. 2016. 144p. Tese (Doutorado) - Escola de Enfermagem, Universidade de São Paulo, São Paulo, 2016.

\section{RESUMO}

O leite humano pasteurizado vem sendo apresentado como a alternativa mais eficaz para alimentar prematuros e também recém-nascidos cujas mães estejam com alguma dificuldade para amamentar. Para suprir essa demanda, aumentou significativamente a implantação de bancos de leite humano no Brasil e no mundo. $\mathrm{O}$ objetivo desta pesquisa foi conhecer as representações sociais sobre a doação de leite entre mulheres colaboradoras do banco de leite humano em um hospital universitário público. Os referenciais teórico e metodológico utilizados foram, respectivamente, a Teoria das Representações Sociais e a Análise de Conteúdo. Para os dados quantitativos, foi utilizada a análise estatística descritiva. Foram entrevistadas 30 mulheres cadastradas como doadoras no Banco de Leite Humano do Hospital Universitário de Londrina, no Paraná. A idade variou de 18 a 44 anos, a maioria teve seus filhos por cesariana, 96,7\% estavam com o companheiro, $86,7 \%$ possuíam curso superior completo ou pós-graduação, $76,7 \%$ exerciam trabalho remunerado fora de casa, o maior volume de leite doado foi 88 litros, o tempo médio de doação foi 155 dias e o tempo médio de aleitamento materno foi de 371 dias. Das falas dessas mulheres emergiram quatro temas com suas respectivas categorias: $\mathrm{A}$ experiência de amamentap; $\mathrm{O}$ banco de leite humano: lugar de acolhimento e aprendizagem; A doação dá trabalho e exige compromisso e Ser doadora é compartilhar o que tem e ajudar a quem precisa. A gênese para uma mulher se tornar doadora é estar amamentando seu filho e esse processo, proveniente da sua vivência familiar, apresenta-se como tendo um lado bom e outro que exige desafios, mas ela percebe que seu leite é único, que sua produção é mais do que suficiente para seu filho, levando essa mulher a procurar o banco de leite para compartilhar esse alimento com outras crianças. O banco de leite se torna para ela um local de acolhimento, apoio e aprendizado e ela se torna divulgadora desse serviço. Também passa a conhecer as histórias de doação e constata que doar seu leite dá trabalho, mas o compromisso assumido supera tal dificuldade; o apoio da família é essencial e ela descobre a sua maneira de ordenhar esse leite. Expressa que sente muito orgulho por ser uma doadora e, ao se perceber nessa condição, as suas representações sociais vinculam-se à construção social da solidariedade e de um sentimento mais profundo do significado da maternidade, que Ihes propicia o sentimento de ampliar, para além de seu filho, o sentir ser mãe de muitos, em que compartilhar o que tem e ajudar a quem precisa resulta na sensação de ver mulptiplicado o papel materno e conhcer que doar vale a pena. Os elementos aqui identificados oferecem subsídios importantes para a condução de campanhas e projetos de melhoria de adesão de doadoras nos trabalhos dos Bancos de Leite Humano.

Palavras-Chave: Banco de Leite Humano. Leite Humano. Aleitamento Materno. Doadoras. 
OLIVEIRA, M. M. B. DE. Social representation of women who are human milk donors. 2016. 144p. Thesis (Doctorate Degree) - Nursing College, Universidade de São Paulo, São Paulo, 2016.

\section{Abstract}

Pasteurized human milk has presented itself as the most effective alternative to feed preterm babies as well as newborns whose mothers are having some difficulty to breastfeed. In order to supply this demand, the number of human milk banks has significantly increased worldwide and in Brazil as well. The aim of this study was to acknowledge the social representation of human milk donation among women who donated to a human milk bank from a public hospital. The Social Representation Theory and Content Analysis were used as theoretical and methodological approaches, respectively. Quantitative data was assessed using descriptive statistical analysis. Thirty women were interviewed, all were donors at the Human Milk Bank from Londrina's University Hospital, in Paraná State. Their age ranged from 18 to 44 years old, most had caesarean-sections, $96.7 \%$ had a companion; $86.7 \%$ had higher education or were postgraduates; $76.7 \%$ had a paid job; the biggest amount of donated milk was 88 liters; average donation period was 155 days; and average breastfeeding period was 371 days. Four themes and categories emerged from the women's speeches: The breastfeeding experience; The human milk bank: a welcoming and leapning place; Donating is hard-working and demands commitment; and Being a donor is sharing what I have and helping with others need. What motivates a woman to become a human milk donor involves the experience of breastfeeding her baby, which presents itself as a positive attitude, however posing some challenges. She realizes that her milk is unique, that she produces more than her baby can take, so she goes to the milk bank to share this nourishment with other children. The human milk bank becomes a welcoming, supportive and learning place for her, who spreads the word about this service/facility. These women also become aware of donation stories and comprehends that donating their milk is hardworking, but the commitment overcomes the difficulties; family support is essential; and they find out their own way to express the milk. These donating women reveal that they are proud to be a donor, and by acknowledging themselves as such, their social representations link to the social construction of solidarity and a deeper feeling of what maternity means. This allows them to amplify the motherhood feeling, beyond their own child, as they feel they are the mother of many. Also, sharing what they have and helping those in need results in the visualization of the multiplication of the mother's role and understanding that donating milk is worthwhile. The elements identified in this study offer important ground to implement campaigns and projects to improve compliance in Human Milk Bank donations.

KeY-wORDS: Milk Bank. Human Milk. Breastfeeding. Tissue Donors. 
OLIVEIRA, M. M. B. DE. La representación social de mujeres donantes de leche humana. 2016. 144p. Tesis (Doctorado) - Escuela de Enfermería, Universidad de Sao Paulo, Sao Paulo, 2016.

\section{RESUMEN}

La leche humana pasteurizada se ha presentado como la forma más efectiva de alimentar prematuros y recién nacidos cuyas madres están con alguna dificultad para amamantar. Para satisfacer esta demanda, aumentó significativamente el establecimiento de bancos de leche humana en Brasil y en todo el mundo. El objetivo de esta pesquisa fue conocer las representaciones sociales acerca de la donación de leche entre mujeres colaboradoras del Banco de Leche de un Hospital Universitario Público. Los marcos teóricos y metodológicos utilizados fueron, respectivamente, la Teoría de las Representaciones Sociales y Análisis de Contenido. Para los datos cuantitativos, se utilizó el análisis estadístico descriptivo. Se entrevistaron 30 mujeres registradas como donantes en el Banco de Leche Humana del Hospital Universitario de Londrina en Paraná. La edad varió de 18 a 44 años, la mayoría había tenido sus hijos a través de cesárea, el 96,7\% tenía su pareja, el $86,7 \%$ había terminado la universidad o el posgrado, el $76,7 \%$ tenía trabajo remunerado fuera del hogar, la mayor cantidad de leche donada fue de 88 litros, el tiempo medio de donación fue de 155 días y la duración media de la lactancia materna fue de 371 días. De los testimonios de estas mujeres surgieron cuatro temas con sus respectivas categorías: La experiencia de amamantap; El banco de leche humana: lugar de acogida y aprendizaje; La donación requiere trabajo y exige compromiso y $S_{\text {er }}$ donante es compartip lo que se tiene y ayudar a quien necesita. La génesis para una mujer ser donante es estar amamantando a su hijo y ese proceso proveniente de su vivencia familiar, esto se presenta con un lado bueno y otro que le exige retos; pero ella se da cuenta de que su leche es única y su producción es más que suficiente para su hijo, lo que la lleva a buscar el banco de leche para compartir este alimento con otros niños. El banco de leche se convierte en un lugar que la acoge, apoya y de aprendizaje para ella, que la convierte en divulgadora de ese servicio. También conoce las historias de donaciones y comprueba que donar su leche requiere trabajo, y su compromiso supera esta dificultad; el apoyo familiar es esencial y descubre su forma de ordeñar su leche. Expresa su orgullo por ser donante, y en esta condición, sus representaciones sociales están vinculados a la construcción social de la solidaridad y un sentido más profundo del significado de la maternidad, lo que les propicia el sentimiento más allá su hijo, el sentirse madre de muchos, al compartir lo que se tiene y ayudar a quien necesita, resulta en la sensación de ver multiplicado el papel materno y percibir que donar vale la pena. Los elementos aquí identificados, proporcionan informaciones importantes para la realización de campañas y proyecto para aumentar las donantes en los trabajos de los Bancos de Leche Humana.

Palabras Clave: Banco de Leche Humana. La leche humana. La lactancia materna. Donante. 


\section{LISTA DE TABELAS}

TABELA 1 Características das mulheres doadoras de leite humano para o BLH/HUL. Londrina-PR, 2016 ............................................. 55

TABeLA 2 Distribuição das doadoras do BLH/HUL segundo o tipo de trabalho. Londrina-PR, 2016

TABELA 3 Distribuição das doadoras do BLH/HUL segundo a maneira como ficou sabendo do banco de leite. Londrina-PR, 2016 .... 57

TABELA 4 Distribuição das doadoras do BLH/HUL segundo o tempo de doação de leite. Londrina-PR, 2016........................................ 58

TABeLA 5 Distribuição das doadoras do BLH/HUL segundo o tempo de aleitamento materno. Londrina-PR, 2016 


\section{Lista de Abreviaturas e Siglas}

\begin{tabular}{ll} 
AIDS & Acquired Immune Deficiency Syndrome \\
AM & Aleitamento Materno \\
AME & Aleitamento Materno Exclusivo \\
ANVISA & Agência Nacional de Vigilância Sanitária \\
BLH & Banco de Leite Humano \\
BLH/HUL & Banco de Leite Humano do Hospital Universitário de \\
EMBA & Londrina \\
HMBANA & Associação Européia de Bancos de Leite \\
HUL & Associação Norte Americana de Bancos de Leite Humano \\
iberBLH & Programa Iberoamericano de Bancos de Leite Humano \\
IBGE & Instituto Brasileiro de Geografia e Estatística \\
IHAC & Iniciativa Hospital Amigo da Criança \\
LH & Leite Humano \\
ODM & Objetivos do Desenvolvimento do Milênio \\
OMS & Organização Mundial da Saúde \\
OPAS & Organização Panamericana de Saúde \\
rBLH & Rede Brasileira de Bancos de Leite Humano \\
SINASC & Sistema de Informações de Nascidos Vivos \\
SUS & Sistema Único de Saúde \\
TRS & Teoria das Representações Sociais \\
UCIN & Unidade de Cuidados Intermediários Neonatais \\
UTIN & Unidades de Terapia Intensiva Neonatal \\
\hline
\end{tabular}




\section{SUMÁRIO}

1 INTRODUÇÃO

1.1 Motivação Para Definição do Objeto do Estudo

1.2 Banco de leite humano: Trajetória

E RELEVÂNCIA SOCIAL …............................................................. 20

1.3 A Doação do Leite Humano e a Doadora …............................... 31

2 OBJETIVO …….................................................................................... 34

3 BASES TEÓRICO-METODOLÓGICAS …............................................ 36

3.1 Marco Conceitual - Teoria das

REPRESENTAÇÕES SOCIAIS .......................................................... 37

3.2 Procedimentos Metodológicos ..................................................... 45

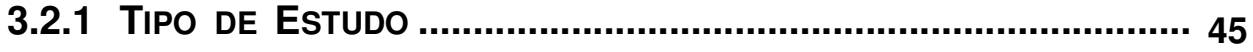

3.2.2 O CENÁRIO DO ESTUDO .......................................................... 46

3.2.3 As PARTICIPANTES DO EstUdo ........................................... 48

3.2.4 A ColetA DE DADOS ............................................................. 48

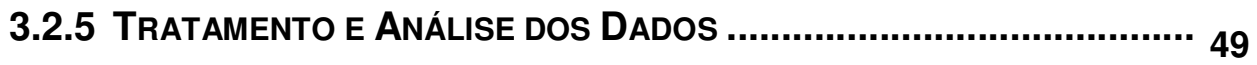

3.2.6 Aspectos Éticos da Pesquisa ….................................... 51

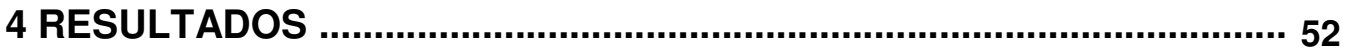

4.1 Perfil das Doadoras ................................................................ 53

4.2 As Representações Sociais das MulHeres:

Doar Vale a Pena. é Ser Mãe de Muitos ……........................... 59

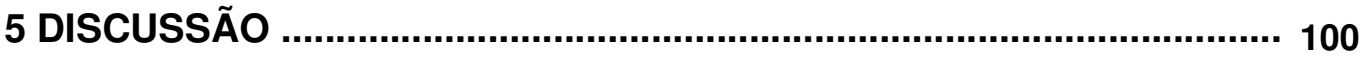

5.1 Perfil das Doadoras de leite Humano .................................... 101 


\subsection{As Representações das Doadoras}

DE LEITE HUMANO .......................................................................... 107

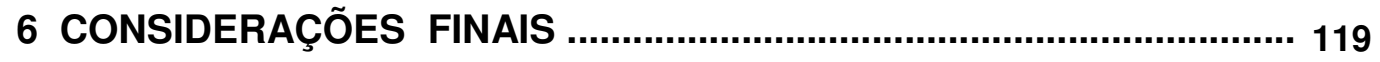

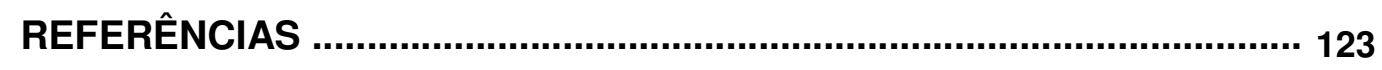

\section{APÊNDICES}

APÊNDICE A - Termo de Consentimento Livre e Esclarecido .................... 137

\section{ANEXOS}

ANeXo A - Parecer do Comitê de Ética em Pesquisa ......................................... 140

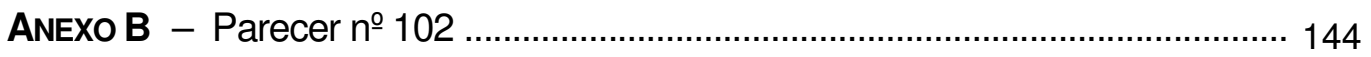




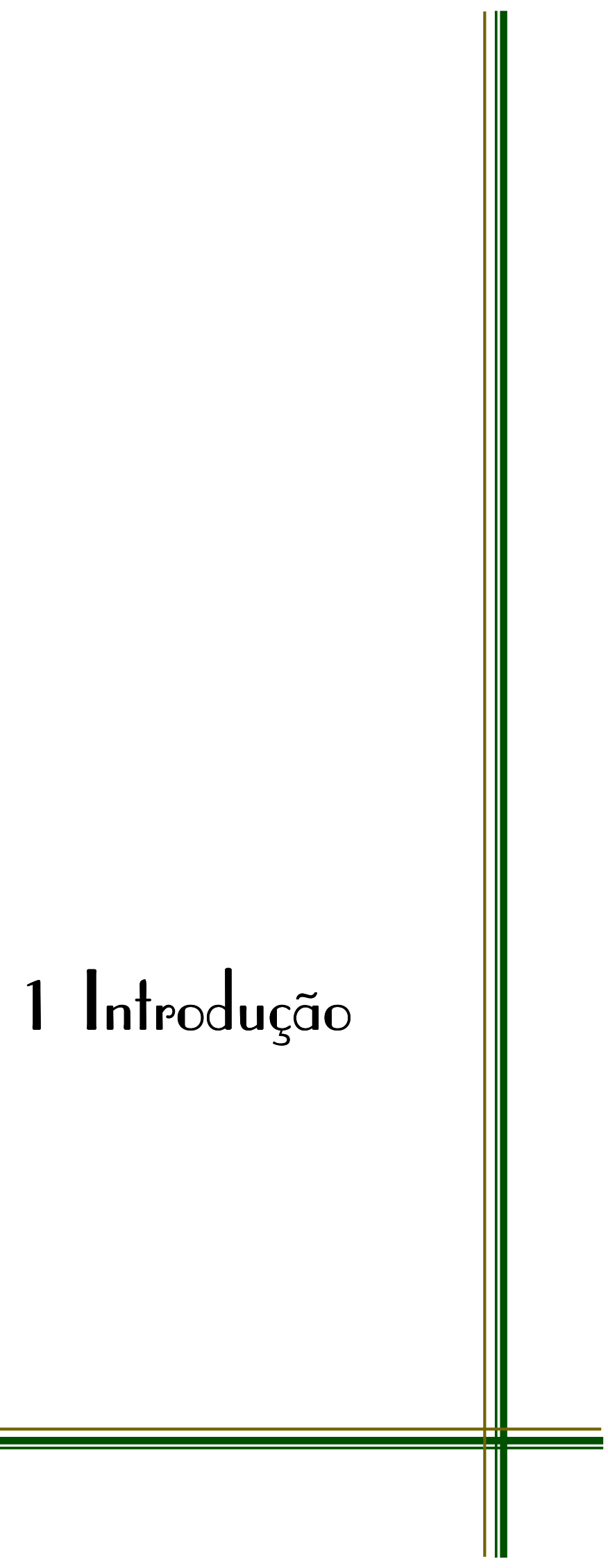


1 Introdução

\subsection{Motivação Para Definição do Objeto do Estudo}

Refletindo sobre minha vida profissional e pessoal, percebo que desde pequena sempre estive envolvida com a criança: cuidando dos filhos das amigas de minha mãe que nos visitavam; optando pelo curso Normal para poder ser professora; escolhendo voluntariamente a unidade pediátrica do Hospital Universitário de Londrina para desenvolver todo meu estágio supervisionado na disciplina de Administração em Enfermagem do Curso de Graduação em Enfermagem; decidindo fazer estágio extra-curricular em uma unidade pediátrica de 65 leitos de um hospital geral - em uma das minhas férias de fim de ano - e trabalhando, pela primeira vez como enfermeira, nessa mesma unidade de onde saí, tempos depois para Especialização em Pediatria e Puericultura na Escola Paulista de Enfermagem da Universidade Federal de São Paulo, vindo a assumir o cargo de docente da disciplina de Enfermagem Pediátrica na Universidade Estadual de Londrina (UEL), mesma instituição em que me graduei enfermeira. Quando começou a integrar essa minha história? Na verdade, sempre esteve presente.

Lembro que antes da criação do Estatuto da Criança e do Adolescente, em 1990, quando o contato mãe-filho era praticamente proibido a mulheres que não podiam pagar uma acomodação hospitalar particular, sempre possibilitei que as mães ficassem com seus filhos, e todas as que estavam amamentando tinham um lugar especial para fazê-lo, ainda que sem conforto.

Depois de iniciar as atividades docentes no Departamento de Enfermagem da UEL, fomos, juntamente com as outras professoras, responsáveis pela implantação do Banco de Leite Humano (BLH) do Hospital Universitário de Londrina, em 1988.

Ao longo dessas três últimas décadas, atitudes e conhecimentos de muitos profissionais envolvidos com o aleitamento materno foram se incorporando aos meus, e hoje minha imagem profissional está sempre associada a um banco de leite humano ou a uma mãe amamentando seu filho. Essa trajetória acabou por me trazer ao Programa Interunidades de Doutoramento em 
1 Introdução

Enfermagem na Escola de Enfermagem da Universidade de São Paulo e Escola de Enfermagem de Ribeirão Preto da Universidade de São Paulo.

No mestrado, já envolvida com o $\mathrm{BLH}$ e constatando a importância desse alimento para os prematuros, pesquisei sobre aleitamento materno entre prematuros nascidos no Hospital Universitário de Londrina, instituição onde está inserido o $\mathrm{BLH}$ em que atuo. Pelos resultados obtidos, foi muito gratificante constatar que o leite humano processado naquele banco contribuiu para o aumento da prevalência do aleitamento materno na população de prematuros estudados, quando comparada com trabalhos anteriores realizados no mesmo serviço.

Uma questão, porém, permanecia inquietante: o BLH conseguia suprir totalmente a demanda específica de leite humano para esses usuários? A resposta, infelizmente, era não. Por isso, o grande desafio dos BLH é aumentar a captação de doadoras e, consequentemente, aumentar a oferta de leite humano pasteurizado. Há pesquisas sobre doação de leite humano e perfil das doadoras, embora muitas vezes não esclareçam o que leva essas mulheres a decidir pela doação ou interrupção do ato de doar. À vista disso, observam-se lacunas no conhecimento a respeito das reais motivações das mulheres para se engajarem no processo de doação de leite e de como tomam a decisão de compartilhar esse benefício com outras crianças e/ou mulheres.

Em estudo comparativo de resultados de teses sobre aleitamento materno, que buscou desvendar as faces da amamentação no âmbito da pesquisa qualitativa, Silva (2000) concluiu que o processo de amamentar está diretamente relacionado aos significados atribuídos pela mulher a essa experiência, e que esse significado é construído por meio de suas histórias de vida e seus relacionamentos, seu contexto e seus projetos de vida.

Ao considerarmos as motivações das mulheres para fazer uma doação voluntária e gratuita do seu leite que excede ao que é ofertado ao seu filho, é possível depreender que, de forma geral, as experiências no seu entorno social e as comunicações sobre o assunto contribuam para uma atitude diante da 
1 Introdução

possibilidade de ser doadora. Aqui procuramos saber se a doação é, de fato, uma decisão individual que corresponde a uma prontidão da mulher para se submeter a esse processo, tendo que adequar o seu contexto de vida para exercer tal prática, sem nenhuma gratificação objetiva ou material.

Apesar de campanhas e demais estratégias que um serviço como - BLH pode implementar para possibilitar acesso a mulheres potencialmente doadoras de leite humano e conquistar a adesão delas, é necessário um entendimento maior sobre o que as motiva a esse gesto. Isso poderia ajudar muito no planejamento de ações dos serviços para captar e manter mulheres doadoras em continuidade de oferta de leite materno para suprir necessidades de bebês com as mais diversas demandas deste importante alimento.

\subsection{Banco de Leite Humano: Trajetória E RELEVÂNCIA SOCIAL}

Os BLH constituem-se em um serviço especializado e respondem pela promoção, proteção e apoio ao aleitamento materno, execução das atividades de coleta do excedente da produção lática da nutriz, seu processamento, controle de qualidade e distribuição (BRASIL, 2006).

No mundo todo, considera-se o aleitamento materno essencial para promover, proteger e manter a saúde das crianças (KUMMER et al., 2000). A superioridade do leite humano na proteção contra doenças infecciosas faz com que especialistas como a Academia Americana de Pediatria recomendem a amamentação exclusiva até os seis meses de vida (CHANTRY; HOWARD; AUINGER, 2006).

Nas últimas décadas, um crescente número de estudos científicos demonstrou que a amamentação é considerada uma estratégia que traz diversos benefícios fisiológicos e nutricionais para a criança, assim como auxilia no seu desenvolvimento neuropsicomotor, além de contribuir para a saúde da mãe. Tais benefícios iniciam-se imediatamente após o parto, persistindo até a vida adulta 
1 Introdução

(BRASIL, 2015). Revisão sistemática realizada por Horta (2007) demonstrou que os indivíduos adultos que foram amamentados apresentaram menores níveis de colesterol, pressão sistólica e diastólica mais baixas e menor risco de diabetes mellitus tipo 2.

Raisler, Alexander e O'Campo (1999) afirmam que, quanto mais tempo um bebê é amamentado, maior é o efeito protetor contra infecções, sendo conhecido como dose-resposta. Esta pesquisa demonstrou que o efeito protetor contra doenças gastrointestinais e respiratórias é mais significativo quando a criança está em aleitamento materno exclusivo do que quando em parcial ou mínimo e que um ou dois meses a mais de amamentação podem fazer a diferença para aumentar a proteção da criança.

Em um estudo de intervenção de promoção do aleitamento materno para observar duração do aleitamento materno, incidência de infecção gastrointestinal, respiratória e de eczema atópico em crianças acompanhadas por 12 meses na República da Bielorrússia, constatou-se que houve aumento na duração do aleitamento materno exclusivo e diminuição do risco de infecção do trato gastrointestinal e eczema atópico no primeiro ano de vida no grupo de crianças que sofreu intervenção (KRAMER et al., 2001).

Chantry, Howard e Auinger (2006) evidenciaram que bebês amamentados exclusivamente por mais de seis meses tiveram quatro vezes menos probabilidade de apresentar pneumonia e duas vezes menos infecções de ouvido do que bebês que foram amamentados somente por quatro a seis meses.

Em um estudo australiano de coorte que acompanhou 2.187 crianças do nascimento até seis anos de idade, encontrou-se redução significativa no risco de asma na infância em crianças de seis anos que foram amamentadas exclusivamente por, pelo menos, quatro meses após o nascimento (ODDY et al., 1999).

Crianças amamentadas exclusivamente têm apenas $12 \%$ de risco de morte em comparação com aquelas que não são amamentadas (VICTORA et 
al., 2016). Diante disso, os autores recomendam o aumento das taxas de aleitamento materno exclusivo como prioridade para a redução de mortes infantis.

Amamentar é considerado, além de tudo, a melhor estratégia de vínculo, afeto, proteção e nutrição para a criança e constitui-se na mais sensível intervenção para a redução da mortalidade infantil, além de promover impacto na promoção da saúde integral da dupla mãe/bebê (BRASIL, 2015).

O leite humano é fundamental para a nutrição de recém-nascidos por ser fonte de diversos compostos imunológicos - incluindo anticorpos, citocinas e células imunológicas, cuja composição se modifica durante todo o período de amamentação para atender às necessidades das crianças -; de imunoglobulina A ( $\lg A)$ secretória, que recobre todo o trato gastrointestinal e protege as crianças amamentadas contra gastrenterites; de prebióticos, que protegem o sistema digestivo de infecções por bactérias patógenas; e de probióticos, como oligossacarídeos e glicanas, que propiciam o crescimento intestinal de Bifidobacterium biffidum, bactérias que protegem a mucosa contra agentes infecciosos, atenuam os processos inflamatórios intestinais e impedem a fixação de agentes patogênicos (MORROW et al., 2005; MUSSI-PINHATA; REGO, 2005; NEWBURG, 2009; NOVAK et al., 2001; PARAMASIVAM et al., 2006).

Em revisão sistemática, Quigley et al. (2007) destacaram que, desde 1997, a Associação Americana de Pediatria recomenda o leite materno como forma mais adequada de alimentação para as crianças prematuras e de muito baixo peso. Ressaltam que, apesar de ser o mais adequado alimento para essas crianças, muitas vezes, por diferentes razões, suas mães não têm o volume suficiente para suprir as necessidades nutricionais dos filhos. As alternativas para solucionar esse problema são o leite humano pasteurizado ou a fórmula infantil específica.

Os prematuros, principalmente os extremos, têm diversos componentes imunológicos imaturos e deficientes, com imunidade inata, humoral, celular e passiva, tornando-os particularmente suscetíveis às infecções nosocomiais (FURMAN et al., 2003). 
1 Introdução

Para os recém-nascidos internados em Unidades de Terapia Intensiva Neonatal (UTIN), o leite humano está relacionado à redução de infecções, da intolerância alimentar, da incidência da enterocolite necrosante e do estresse oxidativo, além de fortalecer o vínculo afetivo entre a mãe e o bebê (OLIVEIRA et al., 2007; SCHANLER et al., 2005).

Em revisão sistemática realizada em 2007, evidenciou-se que os prematuros ou crianças de muito baixo peso ao nascer que receberam fórmula infantil tiveram aproximadamente 2,5 vezes maior risco de enterocolite necrosante quando comparados ao grupo de crianças alimentadas com leite humano (QUIGLEY et al., 2007)

Em especial nesta última década, o leite materno tem sido indicado como o alimento mais adequado para os prematuros. Entretanto, apesar das inúmeras vantagens, alguns fatores podem dificultar o aleitamento materno para essas crianças, como a demasiada ênfase na tecnologia, a hospitalização prolongada e a separação mãe-bebê. Isso pode interferir de maneira negativa na quantidade de leite produzido pela mãe do prematuro (ROSSETTO, 2011; SCOCHI, 2000).

A amamentação de um recém-nascido prematuro pode, em vista disso, ser considerada um desafio tanto para a família como para os profissionais da saúde, porque muitas dessas crianças já recebem prescrição de outros leites na alta hospitalar, provavelmente em razão das muitas dificuldades enfrentadas por suas mães ainda nos primeiros dias pós-parto (SCOCHI et al., 2003).

As crianças a termo também podem necessitar de leite humano pasteurizado dos BLH, como as que nascem com baixo peso, as imunodeprimidas, as que nascem com alguma malformação que necessite correção cirúrgica imediatamente após o parto, as alérgicas à proteína heteróloga existente nos leites de outros mamíferos, as portadoras de diarreia protraída, enfim, todas essas crianças e outras em situações críticas poderiam, havendo estoque, ser receptoras do leite materno doado aos bancos de leite (BRASIL, 2006). 
Uma das estratégias para aumentar a oferta para os recémnascidos internados e com necessidade de ingestão de leite humano é a utilização de leite humano pasteurizado. A política pública de saúde responsável por essa ação é a Rede Brasileira de Bancos de Leite Humano (rBLH). A rede foi regulamentada pelo Ministério da Saúde em 1988, depois de institucionalizar nacionalmente as ações desenvolvidas pelo Instituto Fernandes Figueira (IFF) da Fundação Oswaldo Cruz (Fiocruz). Esse serviço fora implantado em 1943, na cidade do Rio de Janeiro, sendo considerado o primeiro BLH do Brasil, permanecendo até os dias atuais como referência nacional (MATTAR, 2011).

No contexto mundial em que o aleitamento materno não era valorizado, os bancos de leite não tinham destaque. As políticas públicas específicas para essa área eram insipientes. Até a década de 1980, foram implantados no Brasil somente mais cinco BLH (BRASIL, 2016). As atividades desenvolvidas consistiam em coletar e distribuir leite humano para atender casos especiais em que este alimento era considerado imprescindível, usado muito mais como medicamento do que como alimentação propriamente dita. Nessa época, as ações de incentivo à amamentação tinham caráter secundário às ações de coleta e distribuição, dando uma conotação de "leiterias" aos BLH.

O leite humano era distribuído cru a crianças internadas em hospitais com diagnósticos de casos especiais, como prematuridade, perturbações gastrintestinais e alergias a proteínas heterólogas (MAIA et al., 2006).

Ainda naqueles anos oitenta ocorreu uma drástica mudança do paradigma vigente nos BLH no Brasil e no mundo. Com o advento da Acquired Immune Deficiency Syndrome (AIDS), descobriu-se que o Human Immunodeficiency Vírus, ou HIV, poderia passar pelo leite humano. Porém só a partir da segunda metade daquela década os profissionais envolvidos com o aleitamento materno começaram a discutir seu papel neste processo, ampliando a a atuação do BLH para além da distribuição do leite humano.

Essa constatação, somada aos riscos à saúde dos receptores em razão da precária estrutura operacional nos poucos BLH da época, motivou o 
1 Introdução

Ministério da Saúde a exigir uma mudança no perfil do funcionamento desses serviços. O que poderia, aparentemente, ser considerado uma perda pelo fato do vírus poder ser transmitido pelo leite tornou-se um grande ganho, tendo em vista a tecnologia desenvolvida e os avanços atingidos pela rBLH. Para tanto, criou-se, em 1985, uma comissão de especialistas para estruturar uma legislação que oferecesse sustentação para o funcionamento dos $B L H$, propondo um novo paradigma para os procedimentos técnicos e operacionais neste serviço.

Após três anos, essa comissão teve o seu esforço recompensado e o resultado do trabalho se concretizou com a assinatura da Portaria do Ministério da Saúde no 322/88, que se tornou o instrumento legal no Brasil para o funcionamento dos BLH até 2006, servindo de base para a elaboração da Resolução da Diretoria Colegiada (RDC) - Anvisa - n 171, de 4 de setembro de 2006, utilizada até os dias atuais. A partir dessa resolução, passou a ser obrigatória a pasteurização e o exame microbiológico pós-pasteurização como controle higiênico-sanitário para o leite humano a ser distribuído. Esse procedimento garante a inativação de $100 \%$ dos microrganismos patogênicos, até mesmo o HIV, que eventualmente estejam no leite humano, podendo ser oferecido com segurança por sua qualidade certificada, tornando o Brasil referência mundial na área (BRASIL, 1995; BRASIL, 2006).

A década de 1990 foi um novo marco na trajetória dos BLH no Brasil, tendo em vista o investimento em recursos humanos por meio das oficinas de capacitação para os profissionais que trabalhavam nesse serviço ou pela realização dos Encontros e Congressos Nacionais, sendo esses dois eventos os propulsores da criação da rBLH.

A partir dessa década, houve um crescimento significativo no número de BLH no Brasil. Uma das justificativas para este aumento foi a implementação do programa Iniciativa Hospital Amigo da Criança (IHAC), que trouxe um novo olhar para as políticas públicas de aleitamento materno, incluindo os aspectos de proteção e apoio à mulher que amamentava. Até então, a concepção vigente demonstrava um reducionismo biológico, porque considerava somente o aspecto de promoção ao aleitamento materno e à mulher, como a 
1 Introdução

grande responsável pelo sucesso ou não da amamentação (BRASIL, 2006; BRASIL, 2016).

Em 2001, a Organização Mundial da Saúde (OMS) reconheceu internacionalmente o trabalho desenvolvido pelos BLH do Brasil, outorgando o Prêmio Sasakawa ao coordenador dessa rede, Dr. João Aprígio Guerra de Almeida (GIUGLIANI, 2002). O Brasil já foi reconhecido como o país com a maior e a mais completa rede de BLH no mundo, totalizando até o primeiro semestre de 2016 o expressivo número de 220 unidades (BRASIL, 2016).

Ressalte-se que, nas últimas décadas, o número de BLH não aumentou somente no Brasil, mas também no mundo. O Brasil integra o Programa Iberoamericano de Bancos de Leite Humano juntamente com mais 18 países, totalizando $310 \mathrm{BLH}$ (PROGRAMA IBEROAMERICANO DE BANCOS DE LEITE HUMANO, 2016).

$\mathrm{Na}$ Europa, hoje com $210 \mathrm{BLH}$, criou-se a Associação Europeia de Bancos de Leite (EMBA): na América do Norte, a Associação Norte-Americana de Bancos de Leite Humano (HMBANA), que conta com $25 \mathrm{BLH}$, sendo 22 nos Estados Unidos e três no Canadá (EUROPEAN MILK BANK ASSOCIATION, 2015; HUMAN MILK BALKING ASSOCIATION NORTH AMERICA, 2016).

Além desses, existem mais cinco BLH na Austrália e, na África, inicia-se a implantação do serviço naquele continente (AUSTRALIAN GOVERNMENT, 2014; PROGRAMA IBEROAMERICANO DE BANCOS DE LEITE HUMANO, 2016).

Um marco fundamental para o destaque da década de 2000 no Brasil foi o II Congresso Internacional de BLH, realizado em Brasília-DF, em 2005, quando se elaborou a Carta de Brasília, assinada pelos representantes dos países que participaram do evento, entre eles, Cuba, Venezuela, Guatemala, Argentina e Uruguai. Frisou-se na carta a necessidade de estabelecer convênios de cooperação multidisciplinar entre os países signatários e com os Órgãos e Agências de Cooperação Internacional. 
1 Introdução

Um dos elementos motivadores para a realização dos convênios de cooperação é a tecnologia utilizada pela rBLH, eficaz e acessível economicamente a qualquer país, por ser um dos programas de incentivo à amamentação que contribuiu significativamente para que $\circ$ Brasil conseguisse atingir a $4^{\mathrm{a}}$ meta dos Objetivos de Desenvolvimento do Milênio (ODM), que era reduzir em 2/3 a mortalidade de menores de cinco anos, antes de 2015 (PROGRAMA IBEROAMERICANO DE BANCOS DE LEITE HUMANO, 2007).

Outra ação importante foi a criação oficial da Rede Iberoamericana de Bancos de Leite Humano, aprovada como um Programa na XVII Reunião da Cúpula Iberoamericana de Chefes de Estado e de Governo, realizada em novembro de 2007, em Santiago, no Chile. O objetivo dessa rede é promover 0 intercâmbio de conhecimentos e condições para facilitar a transferência de tecnologia no contexto do aleitamento materno e dos BLH como componentes estratégicos na redução da mortalidade infantil (PROGRAMA IBEROAMERICANO, 2016).

O impacto dos números relativos às ações desempenhadas pelos profissionais que atuam nos $220 \mathrm{BLH}$ hoje existentes no Brasil pode ser avaliado por meio do sistema nacional de produção da rBLH. Em 2015, essa rede contabilizou 360.343 atendimentos de mulheres em grupos; 1.666 .765 atendimentos individuais; 176.051 mulheres nutrizes foram responsáveis pela doação de 185.131 litros de leite, tendo sido distribuídos 141.887 litros para 172.267 receptores, prioritariamente recém-nascidos prematuros (BRASIL, 2016).

Em um estudo de caso sobre a rBLH realizado em 2011 pela Organização Panamericana de Saúde (OPAS), destacou-se a liderança do Brasil no desenvolvimento dos BLH como fator decisivo para a expansão dos BLH no cenário internacional (ORGANIZACIÓN PANAMERICANA DE LA SALUD, 2011).

Já no contexto hospitalar, com o recém-nascido internado em UTIN, a ação do BLH pode estimular a relação mãe-bebê e ajudar a mãe a manter a lactação (SCOCHI et al., 2003). Assim sendo, a equipe deve dispor de conhecimentos teóricos e habilidades técnicas para acolher e orientar mães e demonstrar como devem fazer para manter sua produção lática, mesmo 
1 Introdução

separadas de seus filhos. O objetivo é que ela consiga manter a capacidade de produção não apenas enquanto a criança está internada, mas também após a alta hospitalar do bebê, preparando-a para a continuidade do aleitamento.

Os serviços de neonatologia, responsáveis pelo atendimento aos recém-nascidos e, entre estes, especialmente os prematuros, enfrentam alto índice de desmame precoce pelos inúmeros obstáculos que as mães dessas crianças encontram para amamentar após a alta. Na Austrália foram encontrados fatores de dificuldades para a manutenção do aleitamento materno do prematuro, pois frequentemente esse alimento não está disponível para o bebê, talvez pela produção insuficiente em razão do início tardio da lactação, ou pelo parto prematuro, ou porque o recém-nascido prematuro ainda não está em condições de coordenar os reflexos de sucção, deglutição e respiração, ou ainda pela separação mãe-bebê, ou mesmo por ocorrência de uma doença materna (AUSTRALIAN GOVERNMENT, 2014).

$\mathrm{Na}$ atualidade, reconhece-se amplamente que a melhor prática em UTIN é incentivar e apoiar as mães para que amamentem seu bebê diretamente no seio ou extraiam seu leite para alimentar o filho (SPATZ, 2012).

Em trabalho realizado na Espanha, Vasquez Román et al. (2009) afirmam que, em comparação com o leite de fórmula, há comprovação científica dos benefícios do leite humano doado a recém-nascidos prematuros que não contam com leite da própria mãe.

Pesquisa mostra que somente $30 \%$ das mães dos prematuros conseguem prover $100 \%$ desse alimento para seus filhos, sendo este um dos motivos que fazem do prematuro o principal receptor do leite humano pasteurizado, de acordo com a legislação rBLH (ARABI; SCHANLER, 2013; (BRASIL, 2008). Assim, para atender tal demanda, é necessária uma infraestrutura que proporcione captação de leite humano capaz de suprir ao máximo as necessidades desses lactentes.

Segundo Almeida e Dórea (2006), um BLH é um serviço médico importante para prover o melhor alimento para o recém-nascido prematuro, 
1 Introdução

quando isso não for possível por meio de sua mãe, bem como para ser utilizado como tratamento em várias situações clínicas de lactentes. Reforçam também que os programas de aleitamento materno e mães bem motivadas para doar leite são fundamentais para a manutenção dos BLH.

A rBLH trabalha com a estimativa de que $20 \%$ do total de lactantes têm produção láctea superior às necessidades do próprio filho, sendo esta a população específica a ser captada para a doação. Segundo o Sistema de Informações sobre Nascidos Vivos (SINASC), em 2014 o Brasil apresentou em 2.979.259 nascimentos e, mesmo o número de doadoras e de beneficiados tendo aumentado significativamente nos últimos anos, estima-se que pouco mais do que $50 \%$ dos recém-nascidos de baixo peso das UTIN do País recebem este alimento (BRASIL, 2014a; 2016).

O Brasil tem adotado políticas públicas contundentes próaleitamento materno para favorecer a saúde materno-infantil e, com isso, reduzir os índices de morbimortalidade dessa população, considerando que a amamentação é a ação que isoladamente, mais causa impacto na concretização desse objetivo. Pesquisa realizada por Venancio et al. (2010) identificou que a prevalência de Aleitamento Materno Exclusivo (AME) em crianças de 0 a 6 meses estava em 41\%, e a duração mediana do Aleitamento Materno (AM) havia aumentado aproximadamente de 1,5 mês, passando de 295,9 dias em 1999, para 341,6 dias em 2008.

Paralelamente a este cenário, observa-se que os resultados no que se refere à redução da mortalidade infantil são bastante promissores, com um declínio da taxa nacional de 47,1 mortes de crianças por mil nascidos vivos em 1990 para 13,82 em 2015, ano limite para atingir as metas propostas no ano 2000 pelos ODM, entre elas, a meta 4 , que estabelecera a redução da mortalidade infantil no País para o índice de 15,7 em 2015. Interessante notar que, quanto mais aumentam as taxas de aleitamento materno, tanto mais diminuem os índices de mortalidade infantil (UNICEF, 2015).

Segundo Venancio, Saldiva e Monteiro (2013), embora tenha havido aumento dos índices nacionais de amamentação nas últimas décadas, o 
1 Introdução

Brasil precisa vencer importantes desafios. Ressaltam que somente se acelerar o ritmo de crescimento desses índices é que o País conseguirá alcançar um panorama satisfatório em relação à amamentação, atingindo então o índice de duração do AM maior que 20 meses e prevalência do AME em menores de 6 meses acima de 50\%, conforme recomendação da OMS.

A contribuição da rBLH neste cenário constitui-se nas ações de promoção, proteção e apoio ao AM, muito mais do que nas ações específicas de processamento do leite humano coletado. Além disso, no cenário mundial, a rede brasileira é a que tem o maior número de unidades e, consequentemente, a que processa a maior quantidade de leite por ano. Em decorrência disso, o número de crianças beneficiadas com essas ações é elevado, o que interfere de maneira significativa na redução dos danos à população infantil (BRASIL, 2016; MAIA et al., 2006).

Mesmo com o número crescente de BLH no Brasil e no mundo, a grande quantidade de leite coletado ainda não é suficiente para suprir a demanda existente. Parte desse leite pode ser obtida por meio das próprias mães dessas crianças, mas grande parte desse volume tem sido captada de mulheres doadoras, que nem sempre se engajam nessa ação ou a interrompem depois de um tempo de doação do leite residual.

Em vista disso, essa pesquisa busca oferecer subsídios para compreender quais são os elementos que constituem a motivação das mulheres para a doação, supondo que as experiências de vida que contribuem para a formação de representações sociais em seu entorno podem ser a base para suas ações e seu papel como doadoras de leite humano. 
1 Introdução

\subsection{A Doação do Leite Humano e a Doadora}

Assim como a doação de sangue, a doação de leite humano é considerada um gesto altruísta e solidário. A pessoa, neste caso, a mulher que amamenta, vai compartilhar algo que é seu e também de seu filho com outras crianças que estão precisando deste alimento.

Pesquisa realizada por Fergusson e Bibby (2002) demonstrou que há uma característica peculiar sobre os doadores de sangue, considerados ocasionais quando têm quatro ou menos doações em um determinado tempo, e regulares quando têm cinco ou mais doações. A característica mais significativa para cada um desses tipos de doadores foi, respectivamente, intenção de doar e experiência anterior de doação, o que talvez possa ser também características das doadoras de leite humano.

Em comparação com o AM, questão amplamente estudada no mundo, pouco se tem publicado sobre o tema doação de leite humano. Para os profissionais que trabalham nessa área, reconhecer qual é a mola propulsora que leva a mulher a optar por esse gesto solidário poderá favorecer a expansão da doação desse alimento vital. A doadora deve ser considerada a pessoa mais importante para os BLH, tendo em vista que, se não houver o produto por ela doado, não será possível beneficiar o receptor.

Observa-se que, no Brasil, ao longo das duas últimas décadas, a doação de leite humano aumentou significativamente, acompanhando a prevalência do AM. Ainda assim, todos os esforços para uma maior captação de leite humano são de fundamental importância para a redução da mortalidade infantil, e os BLH tornam possível a concretização do gesto da doação.

De acordo com a RDC no 171/2006, que dispõe sobre 0 regulamento técnico para o funcionamento de $\mathrm{BLH}$, a doadora deve preencher algumas condições, entre elas: estar amamentando seu filho, não apresentar doença que comprometa a qualidade do leite humano a ser doado, não fazer uso de medicamento incompatível com a amamentação, apresentar exames pré ou pós-natal que a habilite tanto para a amamentação do filho como para a doação 
1 Introdução

de seu leite, não usar álcool ou drogas ilícitas, apresentar resultados de exames de hemograma completo e sorologia negativa para sífilis, hepatite e aids que atestem as boas condições para doação de leite humano (BRASIL, 2006).

Devem ainda apresentar secreção lática superior às exigências do seu bebê, doando somente o leite excedente, ou seja, aquele volume percebido pela mulher após amamentar, que muitas vezes lhe dá sensação de desconforto e peso nas mamas. Essa doação deve ocorrer de maneira livre e espontânea e é recomendável que a doadora, preferencialmente, não seja tabagista ou que, pelo menos, não fume mais que 10 cigarros ao dia (BRASIL, 2006).

A captação de doadoras é feita de diversas maneiras, podendo ser individual ou coletiva, de forma verbal ou por orientações escritas. As mulheres podem ter contato com o assunto nos grupos de gestantes, obtendo esclarecimentos já no pré-natal, no pós-parto, ou ainda receber orientações individuais feitas às puérperas internadas nas maternidades (ALENCAR, 2008; ANDREASSA; APRILE, 2011).

Também há as que tomam conhecimento quando são atendidas em serviços de acompanhamento pós-natal por dificuldades na amamentação, ao serem atendidas pelas equipes de Saúde da Família ou Unidades Básicas de Saúde nos acompanhamentos de puericultura, ou ainda pelos meios de comunicação, imprensa falada e escrita, que são parceiros imprescindíveis para que a população saiba de tal necessidade (ALENCAR, 2008; ANDREASSA; APRILE, 2011).

No contexto do serviço onde este estudo foi realizado, observouse que muitas mulheres que estão amamentando, ao tomar conhecimento da importância da doação do leite humano, sensibilizam-se com a questão e se oferecem como doadoras. Isso acontece com frequência na primeira semana de lactação, quando ocorre um aumento significativo das mamas e da produção láctea. Ou, ainda, nessa fase, caso tenham a informação de que podem ser doadoras - atualmente isso ocorre de maneira significativa pela mídia -, elas entram em contato com o BLH para colaborar. 
Entretanto também é comum, conforme observado por parte da equipe do serviço, que muitas mulheres demonstrem frustração, já que, depois de se sensibilizar com as divulgações nos meios de comunicação e se colocar à disposição para ser doadoras, percebem que não conseguem coletar e armazenar seu leite. Isso talvez se deva, em parte, aos inúmeros papéis que desempenham, tais como aprender a ser mãe, realizar todas as atividades que esse papel the confere, cuidar de si mesma, cuidar dos afazeres domésticos e das atividades profissionais, dar atenção ao companheiro e aos outros filhos, bem como a familiares e amigos. O estudo de Silva (2000) refere que não é raro esses elementos conflitarem com o processo de amamentar. É de se supor que isso se intensifique ao envolver a ação de doação do leite.

Isso posto, considera-se que o conhecimento sobre questões mais subjetivas e do entorno dessas mulheres pode facilitar a ação dos profissionais na abordagem e na proposta de elementos facilitadores $e$ promotores da sua adesão à doação do leite, de forma espontânea e autônoma.

Acreditamos que a importância deste estudo está nas contribuições que trará aos profissionais que atuam em BLH na compreensão do fenômeno "doação de leite humano" para planejar ações de captação desse alimento para melhoria da qualidade de vida de crianças em situações de risco, cujas mães não conseguem amamentá-las. 


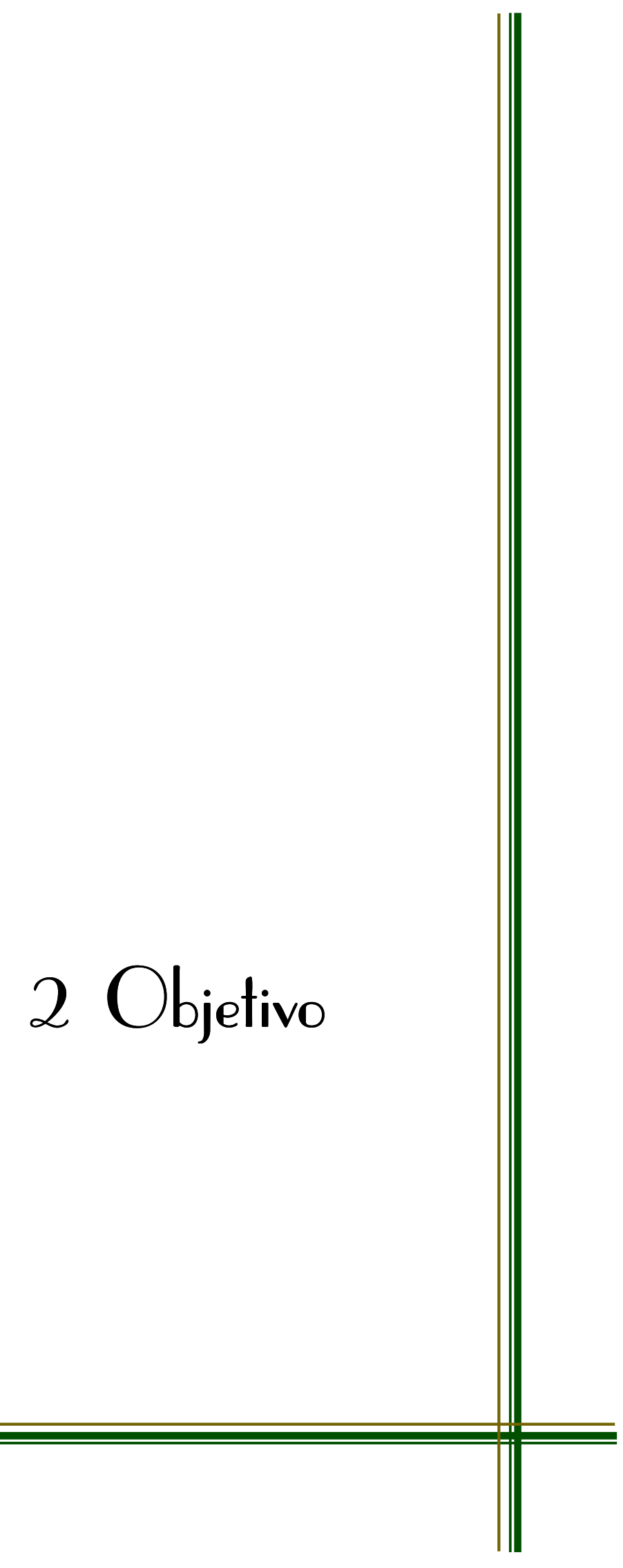


- Conhecer as representações sociais sobre a doação de leite entre mulheres colaboradoras do banco de leite humano em um hospital universitário público. 


\section{Bases Teórico-Metodológicas}


3 Bases Teórico-Metodológicas

\subsection{Marco Conceitual - TEORIA das REPRESENTAÇÕES SOCIAIS}

A Teoria das Representações Sociais (TRS) constitui um marco conceitual relevante, pois permite entender as representações que as pessoas constroem sobre sua realidade e sobre os atos que as cercam e, assim, compreender como as interações grupais podem influenciar o comportamento dos indivíduos (MOSCOVICI, 2015).

A TRS foi proposta em 1961 por Serge Moscovici, representante da escola psicossocial construtivista francesa, em sua tese de doutorado intitulada "La Psicanalyse: son imagine et son public", em que objetivou compreender como o novo fenômeno da psicanálise se disseminava e era incorporado na cultura francesa (MOSCOVICI, 2015).

O autor destaca que essa teoria tinha como propósito resgatar o conceito de representação coletiva proposto por Émile Durkheim para a sociologia. Contudo, enquanto Durkheim considerava que as representações individuais divergiam das coletivas e que ambas eram estáticas, Moscovici preocupou-se em demonstrar a dinamicidade delas de forma a adequá-las ao campo da psicologia social.

O dinamismo dessa teoria está relacionado ao fato de considerar os novos elementos incorporados e as explicações a eles referidas, dando um sentido singular às interpretações dos indivíduos, segundo um dado fenômeno. Para Moscovici (2015), a principal função dessa teoria era familiarizar as experiências, ou seja, "domar o desconhecido", de modo a torná-lo um território seguro, uma vez que a sensação está naquilo que nos é familiar.

A origem da TRS ocorreu em meio a um contexto histórico no qual se vivenciava uma excessiva valorização dos conhecimentos científicos, em detrimento dos saberes relacionados ao senso comum. Insatisfeitos com a realidade, os pensadores da época iniciaram uma tentativa de retomar os pensamentos elaborados a partir das diferentes percepções sociais, com o intuito de ressaltá-los como formas válidas de cultura (ROCHA, 2014). 
Desse modo, nota-se que Moscovici não construiu a teoria de forma isolada da cultura existente: mesmo diante das divergências de pensamento, apoiou seus conceitos em Durkheim. Houve um aprimoramento do propósito inicial de apenas observar como a sociedade se comportava de maneira coesa. Ao estudar as representações sociais na psicanálise, avançou, por buscar compreender como os indivíduos reagiam frente à disseminação dessa nova área de estudo. Os resultados demonstraram que as representações eram identificadas tanto no fenômeno quanto na mente dos indivíduos e, por isso, deveriam ser investigadas em ambos os cenários. Contudo ressalvou que o estudo das representações precisava ser realizado somente após estarem difundidas na sociedade, para que refletissem a realidade do grupo (FARR, 1995).

Ressalte-se que as representações sociais podem ser consideradas como a forma de pensar de maior propagação na sociedade e permeiam o dia a dia dos grupos, visto que, ao se relacionar com o ambiente, objetos ou pessoas, os indivíduos buscam explicações e significados. Estes, manifestados por meio da comunicação, são constituídos por teorias criadas ou adequadas para expressar a forma de compreender determinada realidade (RODRIGUES; RANGEL, 2013), o que se presume que ocorra com as mães que vivenciam a experiência de doar o leite materno.

A TRS forneceu um novo significado ao senso comum, o qual deixou de ser compreendido como uma série de ideias desorganizadas e confusas e passou a ser visto como uma contextualização do conhecimento científico, adequado à linguagem do grupo, mas sem alterar o conteúdo inicialmente proposto. Com isso, permite a difusão dos saberes, a fim de torná-lo compreensivo para qualquer indivíduo: uma forma de partilhar conteúdos já estabelecidos a partir da inserção de novas percepções (SANTOS, 2013).

As representações não são construídas para relacionar as ideias à realidade do fenômeno ou para explicar o caos e a complexidade do mundo. Ao contrário, trata-se de uma tentativa de desenvolver um elo entre algo estranho ao indivíduo e aquilo que lhe é familiar (MOSCOVICI, 2015). 
O que se pode inferir, ainda justificando este estudo, é que as representações sejam uma base do processo de inserção da mulher no universo da doação de leite quando ela, supostamente, estabelece uma interface entre o processo de amamentação, já incorporado em seu dia a dia, e a doação de leite humano, a qual pode ser compreendida como uma experiência ainda não explorada, porém percebida e, de alguma forma, representada em seu contexto.

As representações desempenham uma função cognitiva que busca complementar determinados papéis da identidade social, como a fuga frente a uma nova realidade. Nesse caso, os indivíduos utilizam uma estratégia de ancoragem para familiarizar um evento novo e inevitável e, assim, integrá-lo à série de fenômenos conhecidos. Atuam como uma forma de saber que permite relacionar uma pessoa a determinado objeto, que, por sua vez, atribui símbolos e significados àquele processo (JODELET, 2001).

As representações sociais são, portanto, formas de comportamento criadas a partir de uma realidade consensual, definidas como imagens construídas no espaço público e, por isso, possuem um caráter dinâmico e relacional, compatível com a trajetória do contexto em que foi criada. Nesse processo, os indivíduos utilizam categorias que classificam as circunstâncias, as pessoas, fazem representações sobre seus corpos, suas experiências e sobre suas vidas (MOSCOVICI, 2015).

As representações constituem ainda uma maneira de pensar e interpretar a realidade cotidiana, uma forma de conhecimento desenvolvida por um indivíduo ou grupo para fixar sua posição sobre um evento, situações, objetos e comunicações com os quais se relaciona. Pode-se apreender que é um modo de conhecimento prático, que fornece sentido aos eventos que nos são normais.

A teoria das representações sociais considera a complexidade das pessoas, dos fenômenos e das atitudes, tendo o foco de desvendar como os indivíduos ou grupos podem criar uma realidade estável diante de tamanha diversidade. Além disso, pauta-se na premissa de que, normalmente, as pessoas agem sob influência de dois conjuntos de motivações que atuam de forma 
3 Bases Teórico-Metodológicas

simultânea, os quais compreendem a "relação de causa e efeito" e a "relação de fins e meios" (MOSCOVICl, 2015, p. 80).

Assim, quando o indivíduo se depara com uma pessoa que não se encaixa no estereótipo de suas representações, tende a buscar uma explicação para tal situação. Esse movimento, denominado por Moscovici como causalidade primária, o instiga a descobrir os sentidos ocultos dos comportamentos e das intenções de outras pessoas; entretanto, na maioria das vezes, não consegue compreendê-los (MOSCOVICI, 2015).

Além dessa espontaneidade primária, o indivíduo ou grupo tende a praticar a causalidade secundária, que busca analisar os fenômenos do mundo de maneira imparcial, com base em recursos como os conhecimentos acadêmicos, a visão de mundo e a linguagem adquirida ao longo de sua vida. Para tanto, reúne informações que permitem identificar as causas para a ocorrência da situação, para que, assim, possa explicá-la (MOSCOVICI, 2015).

Outro pressuposto afirmado por Moscovici refere-se à consideração de que as representações são variáveis independentes que determinam tanto a forma como se percebe o estímulo, quanto a resposta que 0 indivíduo fornece diante da situação. Portanto identificar os estímulos e compreender os seus significados constituem o ponto de partida para analisar as relações sociais e prever o comportamento dos envolvidos (MOSCOVICI, 2015).

Segundo Shiele e Bourcher (2001), as representações são construídas e moldadas segundo as relações interpessoais estabelecidas entre os indivíduos e também com o mundo em que vivem; não são estáticas e alteram-se conforme o modo de propagação, que, por sua vez, dependerá das formas de comunicação estabelecidas no grupo. Consequentemente a adoção desses constructos teóricos para o estudo se dá pelo fato de se pressupor que as crenças que as mulheres possuem em relação à prática de doação de leite humano também podem influenciar as representações delas sobre essa realidade e, assim, contribuir para que se tornem ou não doadoras, da mesma forma que podem contribuir para a consolidação ou não de representações já existentes e influenciar novas doadoras. 
As representações podem ser consideradas "sociais" por serem construídas de forma impessoal, referirem-se às percepções de outros indivíduos pertencentes a um grupo e, ainda, por envolverem a representação do ego de cada pessoa. Os conteúdos e sentidos atribuídos a determinados fenômenos alteram-se em um mesmo grupo, fato que pode estar associado aos diferentes meios de pensar expressos em uma cultura, o que contribui para o surgimento de significados distintos sobre um mesmo acontecimento (MOSCOVICI, 2001).

Os comportamentos e as atitudes dos indivíduos são determinados pelas representações sociais, pois estão relacionados à forma como interpretam os acontecimentos e como interagem com o grupo. Atuam como um processo de apreensão da realidade externa e processamento de ideias, influenciadas por essas experiências sociais (JODELET, 2001).

Nesse sentido, as representações são construídas com base na tentativa de se compreender as diferentes situações vivenciadas no dia a dia, como adaptar-se a elas e, assim, definir o modo de se comportar. Estão presentes nas falas, mensagens e imagens utilizadas para manifestar as opiniões e os sentimentos das pessoas ou dos grupos frente a uma realidade (JODELET, 2001).

De acordo com Moscovici (2001), as pessoas são influenciadas pelo meio em que vivem e, nesse contexto, geram e determinam seus pensamentos. Essa premissa torna-se clara na afirmação abaixo:

O indivíduo sofre a pressão das representações dominantes na sociedade e é nesse meio que pensa ou exprime seus sentimentos. Essas representações diferem de acordo com a sociedade em que nascem e são moldadas. Portanto, cada tipo de mentalidade é distinto e corresponde a um tipo de sociedade, às instituições e às práticas que Ihes são próprias (MOSCOVICl, 2001, p.49).

Dessa forma, podem ser consideradas como produtos de uma sociedade, e sua análise deve incluir o contexto no qual foram construídas. A atividade de constante reinterpretação, decorrente do processo de criação das representações, constitui o principal foco do estudo psicossocial (SPINK, 2001). 
Importa destacar que as representações sociais são relacionadas às crenças e aos valores de um grupo, sendo norteadas por referenciais já existentes. Diante disso, os novos acontecimentos tendem a ser inseridos nessas perspectivas familiares para se tornarem aceitáveis aos membros daquela cultura (MOSCOVICl, 2015).

Assim, para compreender o modo como são estruturadas, é necessário considerar que as representações não se referem apenas a um conjunto de representações individuais, da mesma maneira que uma sociedade não pode ser definida, unicamente, como um agrupamento de pessoas. Para analisá-las, devem-se considerar seus aspectos mediadores, dentre os quais se destacam a comunicação, o trabalho, os símbolos e os mitos que, apesar de suas particularidades, buscam fornecer significados às experiências humanas (JOVCHELOVITCH, 2003).

Essas mediações sociais são preditoras das representações, que, por sua vez, não seriam construídas se os indivíduos não estivessem inseridos em um contexto grupal. Assim são elaboradas, pois apesar das constantes alterações ocorridas no meio social, os acontecimentos continuam a se expressar de forma particular para cada pessoa (JOVCHELOVITCH, 2003).

Para formar as mediações, os indivíduos utilizam duas estratégias básicas: a objetivação e a ancoragem. A primeira torna real um esquema conceitual; trata-se do processo de transformar algo abstrato em um conceito mais tangível, de forma a deixá-lo concreto. Nesse movimento são feitas relações e hierarquizações com aquilo que já é conhecido, uma observação à qual se dá um significado. Dessa forma, acontecem duas operações, as quais constituem naturalizar e classificar um novo conceito (MOSCOVICl, 2015), aqui representado pela doação de leite humano.

Já a ancoragem possibilita a construção de uma rede de significados, quando o indivíduo associa algo que conhece com a situação nova com que se depara, para a compreensão de novos fatos, dando a estes uma definição familiar, de modo que se tornem mais palatáveis e seguros. Isso permite 
compreender o olhar que um grupo lança sobre sua vida cotidiana e como isto influencia sua ação (MOSCOVICl, 2015).

No processo de ancoragem, a memória do indivíduo busca enquadrar o pensamento que está sendo construído com base na nova experiência em um preexistente, relacionado aos antigos eventos. Em contrapartida, também atribui valores que contribuem para a interpretação do ambiente e, dessa forma, atua como um complemento da fase de objetivação (JODELET, 2001).

Destaque-se que as representações sociais possuem duas funções básicas: a primeira refere-se à convencionalização dos eventos, ou seja, a busca por categorizá-los em um determinado modelo, a ser partilhado por um grupo de indivíduos. Por meio desse processo, pode-se compreender como um novo fenômeno é incorporado às convenções já encontradas na sociedade, além de demonstrar que os pensamentos de cada pessoa são influenciados pelas convenções e culturas do meio (MOSCOVICI, 2015).

A segunda função das representações sociais está relacionada ao caráter prescritivo, que compreende a força exercida pela representação sobre um grupo. Essa função constitui a estrutura que precede o pensamento quanto a tradição que indica o que deve ser pensado, de modo que, ao serem introduzidas, determinem a visão de cada indivíduo (MOSCOVICl, 2015).

O caráter prático das representações sociais compreende a busca por gerenciar a relação com o mundo e pode produzir efeitos como distorções, suplementações e subtrações dos conteúdos representativos (JODELET, 2001).

Nas distorções, todos os atributos do objeto estão representados, contudo há uma acentuação ou atenuação singular. Já na suplementação, o indivíduo atribui características e significados que não pertencem ao fenômeno, mas estão presentes em seu imaginário. Por fim, as subtrações referem-se à omissão de atributos, em razão, sobretudo, das pressões sociais (JODELET, 2001). 
As representações sociais são frutos da forma como o homem compreende a sua realidade e, à medida que os indivíduos a constroem, também remodelam a si mesmos. Podem assumir diferentes funções, algumas relacionadas ao âmbito social, por meio da construção de identidades e sentidos coletivos, e outras, que se enquadram na área cognitiva e se referem à capacidade de subsidiar significados e estabilizar as situações vivenciadas (MOSCOVICI, 2015).

O estudo das representações sociais diz respeito, portanto, ao entendimento de como os indivíduos se percebem na relação com a sociedade mais ampla, como se sentem frente à realidade. Trata-se do sentimento que se tem sobre a realidade, as ações e informações que reuniram e transformaram em uma teoria do senso comum, apta para explicar a sua realidade e a si mesmos (ARAÚJO, 1997).

As representações sociais estão em constante transformação e são influenciadas tanto por características históricas de cada grupo quanto por acontecimentos atuais. Assim, ao aplicar a TRS, pode-se compreender a forma pela qual um fenômeno foi gerado, além de permitir desvelar as relações entre indivíduos e sociedade, bem como os fatores que caracterizam suas rotinas de vida (SANTOS, 2013).

Nesse sentido, supomos que a aplicação dessa teoria permite compreender a prática da doação de leite humano desde sua origem, além de considerar o contexto socioeconômico e cultural no qual as mães doadoras estão inseridas e a influência desse contexto sobre suas tomadas de decisões. Dessa forma, as imagens construídas e transformadas a partir das experiências do grupo serão analisadas em profundidade, de sorte que, ao final, as representações sociais reveladas sejam expressões comuns àquele grupo de mulheres.

De acordo com Santos (2013, p. 16-17):

As Representações Sociais expressam, enfim, a forma como cada grupo se organiza e constrói seus significados, através de interações dinâmicas e determinadas historicamente. [...] Assim, qualificar uma representação como "social" equivale a optar pela hipótese de que ela é produzida e engendrada coletivamente. 
Além disso, a utilização das representações sociais fornece subsídios para que o pesquisador apreenda a forma como os próprios participantes percebem a realidade, o que contribui para a compreensão dos comportamentos e atitudes adotados por um grupo em relação ao fenômeno em análise. Portanto sua aplicação torna-se relevante ara a área de enfermagem, pois permite ao profissional enfermeiro elaborar plano de cuidados e intervenções de acordo com as características de cada grupo social e direcionado às interpretações que os indivíduos possuem sobre determinado objeto (SILVA; CAMARGO; PADILHA, 2011).

Diante do exposto, acreditamos que o marco conceitual da TRS pode contribuir para a compreensão das representações sociais que as mulheres possuem sobre a doação de leite humano. Dessa forma, será possível aprofundar o conhecimento sobre o fenômeno a partir da perspectiva das doadoras, amparado em um referencial que permite analisar em profundidade e de forma integradora todas as relações estabelecidas, bem como compreender os sentimentos e imagens atribuídas pelas mulheres em relação a esse processo.

\subsection{Procedimentos Metodológicos}

\subsubsection{TIPO DE EsTUDO}

Para atingir os objetivos do estudo, optou-se pela pesquisa qualitativa, cuja metodologia é capaz de incorporar a questão do significado e da intencionalidade como inerentes aos atos, às relações e às estruturas sociais, podendo dar suporte para o desenvolvimento dos objetos desta pesquisa (MINAYO, 2008). Também se incorpora, de forma introdutória e exploratória, o estudo de variáveis biológicas e sociais das mulheres participantes. 
3 Bases Teórico-Metodológicas

\subsubsection{O Cenário do Estudo}

O estudo foi desenvolvido em Londrina, Paraná, estado que se localiza na região Sul do Brasil, com cerca de 10 milhões de habitantes e 399 municípios distribuídos em aproximadamente 200 mil quilômetros quadrados.

Londrina é o município sede da $17^{a}$ Regional de Saúde e possui 510.000 habitantes, segundo dados do Instituto Brasileiro de Geografia e Estatística (2016). No ano de 2014 ocorreram 411.370 nascimentos no Paraná e 8.499 no município de Londrina (BRASIL, 2014b; 2014c).

O cenário da pesquisa foi o Banco de Leite Humano do Hospital Universitário de Londrina (BLH/HUL). O serviço foi criado em 1988 e, ao longo dos anos, vem ampliando as suas atividades assistenciais e de processamento de leite humano coletado. As atividades assistenciais referem-se às ações de promoção, proteção e apoio, que são muito intensas porque englobam atendimentos de populações distintas: mães que já não estão internadas, mas com filhos prematuros na UTIN e Unidade de Cuidados Intermediários Neonatais (UCIN) do hospital. A maioria delas permanece com seus filhos, quase sempre no período diurno, praticamente todos os dias de internação de seus bebês, tanto para estarem com eles, como para manterem a sua produção láctea, por meio de massagem das mamas e extração do leite a cada três horas, no banco de leite ou em uma sala de apoio na própria UTIN. Esse apoio também se estende a toda e qualquer mulher da cidade ou da região cujo filho não está internado mas que necessita de ajuda para amamentar ou manter a lactação, por apresentar dificuldades com a pega, ingurgitamento, fissuras, mastite, entre várias.

Outra atividade específica do banco de leite é a visita domiciliar diária a qualquer mulher que entre em contato telefônico com o serviço desejando ser doadora, ao perceber que tem leite sobrando. São realizadas de 12 a 20 visitas domiciliares por dia para coleta de leite humano, e essas doadoras são captadas tanto por abordagem direta nas maternidades locais, como também por divulgação pelos meios de comunicação. No momento em que uma profissional da equipe do BLH chega à casa de uma dessas mulheres para preencher uma 
3 Bases Teórico-Metodológicas

ficha de cadastro de doadora, faz as orientações necessárias para a extração e armazenamento do leite ordenhado, segundo recomendações preconizadas pela rBLH e ANVISA.

Além disso, também fornece kit para a doação do leite, contendo frascos esterilizados, etiquetas, gorro, máscara e folder explicativo. Nesse momento, se define a data de retorno, geralmente em uma semana, prazo considerado adequado para a manutenção da conservação do leite ordenhado. A partir daí, esta mulher passa a fazer parte do grupo de doadoras da rBLH (BRASIL, 2006, 2008).

O BLH de Londrina possui cinco postos de coleta, responsáveis pela captação de suas próprias doadoras e do leite humano a ser enviado ao BLH para processamento e controle de qualidade. Num momento posterior, esse produto, parcial ou totalmente, retorna aos postos de coleta para distribuição aos receptores internados em suas respectivas instituições hospitalares.

Assim, além da coleta realizada pela equipe do BLH, esse serviço é responsável por pasteurizar o leite recolhido nos cinco postos de coleta de leite humano, localizados em Londrina e região. A média de volume coletado em 2015 foi de 280 litros/mês, provenientes de mais de 300 mulheres que doaram o excedente do seu leite para aproximadamente 330 crianças a cada mês.

Os meios de comunicação, os grandes aliados desta estratégia, nos últimos anos têm entendido a necessidade de doação como uma questão de saúde pública e como prestação de serviços para a comunidade. Além disso, o Ministério da Saúde tem investido, anualmente, na produção de material didático como folders, cartilhas, cartazes e vídeos explicativos, para sensibilização das mulheres sobre a prática da doação de leite. Essas estratégias, aliadas às campanhas da Semana Mundial de Aleitamento Materno (de 1ํa 7 de agosto) e do Dia Mundial de Doação de Leite Humano (19 de maio), que geralmente alavancam bons espaços na mídia, são instrumentos de valor para a captação de doadoras. 
Em Londrina os meios de comunicação vêm veiculando as campanhas informativas e divulgando a importância da doação em períodos quando o estoque de leite está baixo ou a respeito de qualquer outra necessidade do serviço.

O BLH/HUL integra a rBLH que tem a sua referência nacional no BLH da Fundação Oswaldo Cruz, no Rio de Janeiro. Trabalhando em rede, cada estado tem a sua referência estadual, sendo este BLH a referência para o Paraná desde 2009. Além de todas as atividades assistenciais à mulher que amamenta captação, coleta, processamento, controles de qualidade e distribuição do leite humano ordenhado -, o BLH de referência é responsável pela implementação de ações estratégicas estabelecidas para sua área de abrangência, com atribuição de desenvolver educação permanente, pesquisas operacionais e prestar assessoria técnica aos demais bancos do estado (BRASIL, 2006).

\subsubsection{As Participantes do Estudo}

Fizeram parte desta pesquisa doadoras de leite humano cadastradas no BLH/HUL. O número de mulheres participantes foi definido pelo critério de saturação dos dados qualitativos, quando foi percebida a repetição das informações, o que ocorreu na $30^{\underline{a}}$ entrevista.

\subsubsection{A Coleta de Dados}

A coleta de dados foi realizada no período de julho de 2015 a março de 2016 constando de duas etapas. $\mathrm{Na}$ primeira obteve-se a caracterização das doadoras, por meio dos dados sociodemográficos extraídos da ficha de cadastro de cada doadora no BLH/HUL. As variáveis pesquisadas foram: idade materna, local de moradia, escolaridade, situação conjugal, religião, trabalho fora do lar, tipo de trabalho, jornada de trabalho, total de filhos, tipo de parto, número de vezes em que doou, local do nascimento da criança, volume doado, tempo de doação e tempo de aleitamento materno praticado. 
A segunda etapa consistiu na obtenção dos dados qualitativos, quando foram entrevistadas as doadoras do referido serviço que aceitaram participar da pesquisa, após contato telefônico e agendamento da data da entrevista no domicílio, de acordo com a disponibilidade de ambas as partes. As entrevistas foram gravadas depois de a doadora ter sido esclarecida e assinado 0 Termo de Consentimento Livre e Esclarecido (Apêndice A). Foi utilizada a seguinte pergunta norteadora: $O$ que representou para você doar seu leite para o banco de leite humano?

No decorrer da entrevista, quando necessário, introduziram-se outras questões para aprofundar o tema sobre a representação, motivação e identificação de elementos do entorno social da mulher para manter sua adesão como doadora.

\subsubsection{Tratamento e Análise dos Dados}

Para análise das variáveis quantitativas, foram calculadas frequências, médias e medianas por meio do pacote estatístico SPSS (Statistical Package for the Social Science), versão 20.0.

Para análise dos dados qualitativos, utilizou-se o método de Análise de Conteúdo proposto por Bardin (2010), por favorecer a exploração das relações que os indivíduos mantêm em sua vida, o que constrói suas representações sociais.

A busca pela compreensão dos dados - nesta pesquisa, o discurso de doadoras sobre sua experiência em doar seu leite a um BLH - foi o que motivou a escolha do referencial metodológico de Bardin como categoria de análise, por ter uma suficiência epistemológica que a justifica.

A complexidade desse processo exige que se ultrapasse a compreensão dos significados do senso comum, sendo necessário compreendêlos inseridos em um processo sócio-histórico que lhes dê o verdadeiro significado. A dimensão metodológica da teoria das representações sociais reafirma a 
3 Bases Teórico-Metodológicas

importância da realização das entrevistas colhidas entre as informantes e da sua análise.

Seguindo a proposta da autora do método adotado (BARDIN, 2010), ao iniciar a primeira fase, denominada pré-análise, a pesquisadora organizou os registros das entrevistas e se aproximou do seu objeto de análise. Para isso, fez leitura do material que seria analisado, selecionando aquele que fornecesse mais informações sobre o fenômeno em estudo — neste caso, a doação de leite humano —, seguindo normas, regras e critérios para garantir o rigor científico da pesquisa. Passou, então, para a fase de formulação e confirmação do pressuposto e, na sequência, fez os recortes das falas das doadoras, definindo os temas que dali emergiram. Em seguida, o material obtido foi codificado em unidades que permitiram elaborar a representação do conteúdo.

$\mathrm{Na}$ segunda fase, denominada exploração do material e tratamento dos resultados, o material coletado foi submetido a um estudo aprofundado, com base em princípios, hipóteses e referenciais teóricos, consistindo em operações de codificação, enumeração e categorização, resultando em unidades mais abrangentes, ou unidades de contexto, e em unidades mais específicas, ou unidades de registro.

Concluídas essas etapas, chegou-se à terceira e última fase, denominada inferência e interpretação, em que os resultados obtidos foram submetidos à interpretação, correspondendo ao tratamento dos resultados.

Os relatos foram identificados com a letra $\mathbf{E}$ de entrevista, seguida por um número indicativo da sequência de realização (ex.: E1). 
3 Bases Teórico-Metodológicas

\subsubsection{Aspectos Éticos da Pesquisa}

Para o desenvolvimento deste estudo, foram atendidas as exigências da Resolução 466/2012 do Conselho Nacional de Saúde (BRASIL, 2012).

As mulheres entrevistadas foram esclarecidas sobre os objetivos do estudo e, também da utilização dos dados obtidos em artigos científicos. As participantes tomaram ciência de que as entrevistas seriam gravadas, e as que aceitaram participar do estudo assinaram o Termo de Consentimento Livre e Esclarecido (Apêndice A).

O projeto foi analisado pelo Comitê de Ética em Pesquisa Envolvendo Seres Humanos da Escola de Enfermagem da Universidade de São Paulo, registrado sob o Parecer № 1.105 .438 (Anexo A) e pela Comissão de Avaliação Regimentada de Projetos de Pesquisa Científica do Hospital Universitário da Universidade Estadual de Londrina, autorizando a coleta de dados sob o Parecer no 102 (Anexo B). 


\section{Resultados}


4 Resultados

Os resultados deste estudo estão apresentados em duas seções. A primeira contém o perfil das mulheres doadoras do BLH pesquisadas, no que se refere às seguintes características sociodemográficas: tipo de parto, local do parto, total de filhos, número de vezes em que doou seu leite, situação conjugal, religião, escolaridade, ocupação materna, jornada e tipo de trabalho, como ficou sabendo do banco de leite, tempo da doação, volume doado e tempo de aleitamento materno.

$\mathrm{Na}$ segunda seção, constam os quatro temas com suas respectivas categorias, que foram apreendidos das falas das mulheres doadoras pesquisadas, sendo eles: $\mathrm{A}$ experiência de amamentap; $\mathrm{O}$ banco de leite humano: lugar de acolhimento e de aprendizagem; A doação dá trabalho e Exige compromisso; Ser doadora é compartilhar o que tem e ajudar a quem precisa.

\subsection{Perfil das DoAdoras}

Os dados sociodemográficos das 30 participantes da pesquisa indicam que a maioria $(93,3 \%)$ das doadoras residiam em Londrina. Das duas que não moravam em Londrina, uma era da zona rural do Distrito de Irerê, e a outra do município de Ibiporã, localidades próximas à cidade sede do BLH.

A idade das 30 doadoras do BLH do Hospital Universitário de Londrina variou de 18 a 44 anos, com média de 32,73 anos.

A Tabela 1 mostra os dados de tipo de parto, local do parto, total de filhos, número de vezes em que doou seu leite, situação conjugal, religião, escolaridade e ocupação materna.

Quanto ao tipo de parto, chama atenção o fato de a grande maioria ter sido cesariana. O maior número de partos foi registrado por um hospital filantrópico de Londrina.

Do total das mulheres da pesquisa, 18 tiveram mais que um filho. Interessante observar que $14(46,7 \%)$ dessas doadoras repetiram o gesto de doar 
4 Resultados

após outras gestações, doando mais que uma vez. Em relação à situação conjugal, vale destacar que quase a totalidade das doadoras era casada ou estava em relacionamento estável. Houve predomínio da religião católica entre as participantes.

Quanto à escolaridade, mais de $50 \%$ das doadoras possuíam curso de pós-graduação, não havendo nenhuma sem escolaridade. Do total das doadoras, $23(76,7 \%)$ trabalhavam fora de casa com remuneração. 
TABELA 1 - Características das mulheres doadoras de leite humano para o BLH/HUL. Londrina-PR, 2016.

\begin{tabular}{|c|c|c|}
\hline VARIÁVEIS & $\mathbf{n}=\mathbf{3 0}$ & $\%$ \\
\hline \multicolumn{3}{|l|}{ TIPO DE PARTO } \\
\hline Cesárea & 25 & 83,3 \\
\hline Vaginal & 5 & 16,7 \\
\hline \multicolumn{3}{|l|}{ LOCAL DO PARTO } \\
\hline Hospital Evangélico de Londrina & 20 & 66,7 \\
\hline Hospital Mater Dei de Londrina & 3 & 10,0 \\
\hline Hospital Universitário de Londrina & 2 & 6,7 \\
\hline Outros Hospitais de Londrina e Região & 5 & 16,6 \\
\hline \multicolumn{3}{|l|}{ TOTAL DE FILHOS VIVOS } \\
\hline 1 & 12 & 40,0 \\
\hline 2 & 15 & 50,0 \\
\hline 3 & 3 & 10,0 \\
\hline \multicolumn{3}{|l|}{ VEZES EM QUE DOOU SEU LeITE } \\
\hline 1 & 16 & 53,3 \\
\hline 2 & 13 & 43,3 \\
\hline 3 & 1 & 3,3 \\
\hline \multicolumn{3}{|l|}{ SITUAÇÃO CONJUGAL } \\
\hline Com Companheiro & 29 & 96,7 \\
\hline Sem Companheiro & 1 & 3,3 \\
\hline \multicolumn{3}{|l|}{ RELIGIÃo } \\
\hline Católica & 21 & 70,0 \\
\hline Evangélica & 7 & 23,3 \\
\hline Outras & 2 & 6,7 \\
\hline \multicolumn{3}{|l|}{ ESCOLARIDADE MATERNA } \\
\hline Ensino Médio (2º grau) & 4 & 3,3 \\
\hline Educação Superior ( $3^{\circ}$ grau) & 9 & 30,0 \\
\hline Pós-Graduação & 17 & 56,7 \\
\hline \multicolumn{3}{|l|}{ OCUPAÇÃO } \\
\hline Trabalho doméstico não remunerado & 7 & 23,3 \\
\hline Trabalho fora de casa remunerado & 23 & 76,7 \\
\hline
\end{tabular}


Para as 23 doadoras com trabalho remunerado fora de casa, a jornada laboral variou de 6 a 44 horas semanais; para 9 delas $(30,0 \%)$ a carga horária semanal foi de 40 horas, e para 5 delas $(16,7 \%)$ foi de 30 horas.

As diferentes profissões desempenhadas pelas $23(76,7 \%)$ doadoras que exerciam trabalho remunerado fora de casa estão listadas na Tabela 2.

TABELA 2 - Distribuição das doadoras do BLH/HUL segundo o tipo de trabalho. Londrina-PR, 2016.

\begin{tabular}{lcc}
\hline \hline \multicolumn{1}{c}{ Tipo de TrabalHo } & $\mathbf{n}$ & $\%$ \\
\hline \hline Profissional da Saúde & 9 & 30,0 \\
Profissional & 4 & 13,3 \\
Administrativo & 3 & 10,0 \\
Cabelereira/Esteticista & 2 & 6,7 \\
Bancária & 2 & 6,7 \\
Professora & 1 & 3,3 \\
Cozinheira & 1 & 3,3 \\
Empresária & 1 & 3,3 \\
Personal Trainer & $\mathbf{2 3}$ & $\mathbf{1 0 0 , 0}$ \\
\hline \hline Total & & \\
\hline \hline
\end{tabular}

A Tabela 3 apresenta as diferentes maneiras pelas quais as doadoras entraram em contato com o BLH. Destacam-se entre as formas de obtenção de informações sobre o banco de leite - em especial quanto à possibilidade de doação do leite - o contato direto com profissionais da saúde e também o fato de algumas doadoras exercerem atividades nesta área, portanto conhecedoras do serviço, o que favoreceu a divulgação a respeito do BLH. 
4 Resultados

TABELA 3 - Distribuição das doadoras do BLH/HUL segundo a maneira como ficou sabendo do banco de leite. Londrina-PR, 2016.

\begin{tabular}{lcc}
\hline \hline \multicolumn{1}{c}{ Tipo de Trabalho } & $\mathbf{n}$ & $\%$ \\
\hline \hline Profissionais da Saúde & 10 & 33,3 \\
Meios de Comunicação & 6 & 20,0 \\
Trabalha na Área & 5 & 16,7 \\
Familiar & 3 & 10,0 \\
Amiga & 3 & 10,0 \\
Ex-Doadora & 2 & 6,7 \\
Curso de Gestante & 1 & 3,3 \\
\hline \hline Total & $\mathbf{3 0}$ & $\mathbf{1 0 0 , 0}$ \\
\hline \hline
\end{tabular}

A Tabela 4 apresenta o tempo de doação de leite das doadoras. A maioria $(66,7 \%)$ das mulheres permaneceu aderente ao programa de doação por até cerca de seis meses; as demais $(33,3 \%)$ conseguiram manter a doação de leite por mais de seis meses, uma das quais fez sua doação por mais de um ano, especificamente por 415 dias.

O volume doado por essas doadoras variou de 400 mililitros a 88 litros de leite. 
4 Resultados

TABELA 4 - Distribuição das doadoras do BLH/HUL segundo o tempo de doação de leite. Londrina-PR, 2016

\begin{tabular}{cccc}
\hline \hline \multicolumn{2}{c}{ MESES } & $\mathbf{n}$ & $\%$ \\
\hline \hline Até 3 & & 8 & 26,7 \\
$3-\mid$ & 6 & 12 & 40,0 \\
$6-\mid$ & 9 & 6 & 20,0 \\
$9-\mid 12$ & 3 & 10,0 \\
$>12$ & & 1 & 3,3 \\
\hline \hline TOTAL & 30 & $\mathbf{1 0 0 , 0}$ \\
\hline \hline
\end{tabular}

A Tabela 5 apresenta o tempo de AM das doadoras. Destaca-se que nenhuma delas amamentou menos que seis meses, e duas amamentaram por mais de dois anos.

TABelA 5 - Distribuição das doadoras do BLH/HUL segundo o tempo de aleitamento materno. Londrina-PR, 2016.

\begin{tabular}{cccc}
\hline \hline & MESES & n & \% \\
\hline \hline $6 \longmapsto$ & 9 & 9 & 30,0 \\
$9 \longmapsto$ & 12 & 6 & 20,0 \\
$12 \longrightarrow$ & 24 & 13 & 43,3 \\
$>24$ & 2 & 6,7 \\
\hline \hline & & 30 & 100,0 \\
\hline \hline
\end{tabular}


4 Resultados

\subsection{As RePRESENTAÇões SOCIAIS DAS MulHeRES: Doar Vale a Pena. É Ser Mãe de Muitos}

Foram identificados quatro TEMAS que demonstram elementos importantes na construção de representações e todo o universo consensual de mulheres doadoras de leite humano, a partir do que emerge a disponibilidade para um processo de engajamento, de solidariedade e de partilha do leite produzido.

Esses TEMAS tratam de percepções sobre a sua própria experiência de amamentar, sobre a importância de doar o leite, o seu papel na promoção da saúde de seu filho e dos filhos alheios, desconhecidos, mas que se tornam familiares por receberem seu leite; tratam ainda de sua descoberta do serviço do Banco de Leite, que, mais que um serviço técnico, torna-se uma referência para seu bem-estar e valorização de seu papel de nutriz, de doadora e de cidadã solidária e preocupada com o ambiente. Finalmente, vislumbra-se nos TEMAS a sensação de dever cumprido, de gratificação por ter sido útil e por agregar valor à prática de doar, que vem do sentimento de expansão de sua maternidade.

Os TEMAS identificados:

1. A experiência de amamentar;

2. O banco de leite humano: lugar de acolhimento e de aprendizagem;

3. A doação dá trabalho e exige compromisso;

4. Ser doadora é compartilhar o que tem e ajudar a quem precisa. 


\section{TEMA 1}

\section{A experiência de amamentap}

\subsection{A história da amamentação na família}

\subsection{O lado bom da amamentação}

\subsection{Os desafios da amamentação}

\subsection{O leite humano é único}

\subsection{Produzir bastante leite, ter o suficiente}

O tema A experiência de amamentar é composto por categorias que englobam percepções maternas sobre o seu processo de amamentar em suas dimensões subjetivas e objetivas. As mulheres deste estudo demonstram que a sua percepção sobre a amamentação foi construída no seu universo consensual, tendo como base o conhecimento de senso comum, construído principalmente pela história de amamentação na família. Com base nessa experiência compartilhada, ao vivenciar o seu próprio processo de amamentar, elas deparam com elementos inerentes a respostas biológicas e emocionais e, por sua vez, constroem sua própria história de amamentação, permeadas pelo reconhecimento de que existe o lado bom da amamentação, permeado por sentimentos e alcance de objetivos em amamentar o filho. Porém, segundo elas, essa prática as coloca frente a desafios da amamentação, emergidos de intercorrências e desgaste físico e emocional. Segundo suas crenças de que o leite humano é único, que revelam sua confiança nos atributos do leite materno, elas superam dificuldades e mantém firme seu propósito de produzir bastante leite, ter leite suficiente para seu filho. 


\subsection{A história da amamentação na família}

As mulheres trazem consigo, fortemente, o saber de senso comum construído e aprendido a partir das experiências das mulheres da família e de seu entorno social, mostrando a importância que esse contexto tem em suas vidas, compartilhando a experiência de outras nutrizes, ou, ainda, podendo compartilhar suas experiências anteriores com outras mulheres.

Minha avó sempre amamentou todos os filhos dela, mas minha mãe só amamentou um dos filhos, porque era muito nervosa. E18

Quando as mulheres comparam suas experiências de amamentar com outras, especialmente as da família, elas abstraem ideias, conhecimentos, informações que acabam processando para construir suas percepções sobre 0 processo de amamentar e sobre o que essa prática significa para si mesmas - de início, transformada em expressão de desejo; posteriormente, dando-lhes base para ações práticas no movimento de estabelecer a amamentação. Assim, a partir de um referencial preexistente, elas elaboram suas percepções de amamentar, o que se concretiza em suas experiências, podendo ocorrer ou não ressignificações sobre suas representações de amamentação. Baseadas em experiências, elas constroem uma atitude diante da amamentação.

Eu sempre tive muita vontade de amamentar... Eu fiquei muito feliz quando vi que tinha muito leite. E18

As experiências que essas mulheres têm no seu contexto podem construir uma experiência de amamentação muito valorizada, mesmo que nem todas sejam exitosas. Em sua experiência concreta de amamentar, os demais atores, mesmo que atuais, têm um papel importante, sendo incluídos em seu universo como referência para avaliar e comparar sua prática de amamentar, podendo influenciar as ações e percepções dos outros.

\footnotetext{
“Porque [amamentar] não é o histórico da minha família.” E5
} 
No início, meu marido não incentivava a amamentação e a doação, acho que porque minha sogra não amamentou. Ela sempre dizia que não gostava. Mas meu marido me apoiou e passou a valorizar. Ele sempre me ajudou. E21

A minha irmã mais velha não conseguiu amamentar, e a minha mãe não tinha muito leite, não. Mudou a partir de mim. E depois de mim, a minha irmã caçula teve bebê e tentou a mesma linha. E ela amamenta exclusivo também. Amamenta exclusivo no peito, e isso não era uma realidade da nossa família ... E5

Nessa perspectiva, elas reconhecem que sua experiência é única e que podem ter uma história diferente de outras mulheres com quem conviveram, fazendo sua própria história.

Minha mãe não teve história de amamentação. Mas eu fiz diferente e não tive nada, nem mastite, nada, nada, nada. Eu tive muito leite, adorava amamentar, fiz livre demanda, então era uma loucura! E22

\subsection{O lado bom da amamentação}

As mulheres revelam que a experiência de amamentar está alicerçada, inicialmente, em uma dimensão subjetiva de desejos e expectativas acerca desse processo. A concepção da maternidade, seja ela construída desde antes da gravidez ou durante o processo de gestar, traz em si o desejo de poder amamentar o filho, produzir leite suficiente para garantir a alimentação da criança e dar vazão a uma realização pessoal de ser mãe e provedora do filho.

Em primeiro lugar, eu queria amamentar o meu bebê. E isso NÃO veio da minha infância. A gestação motivou meu desejo para amamentar. O conhecimento que eu fui agregando nesse período intensificou meu desejo de amamentar. Fui estudando e vi que era o melhor para mim e meu filho; busquei muitas informações, muitos temas, inclusive de amamentação, e fui vendo que era o melhor. E5

Nesse contexto, também o reconhecimento acerca dos atributos do leite materno tem lugar em uma dimensão objetiva da realidade, em que as 
mulheres tomam para si informações do universo reificado a respeito do leite e do seu valor para a saúde e sobrevida da criança, atribuindo um valor concreto ao leite que elas produzem.

Eu sou fisioterapeuta e fiz residência em pediatria. Então, quando passei pela UTI pediátrica ... a gente sabia da importância que o leite materno tem. $\mathrm{E} 8$

A amamentação também tem um lado utilitarista e se apresenta na concretude da praticidade de ser um método rápido e pronto de alimentar uma criança.

Pra qualquer lugar que eu vou, meu marido pergunta: 'Tá esquecendo alguma coisa?' Não, meus dois peitos estão aqui! E6

Além disso, as mulheres compreendem que a amamentação lhes proporciona alguns benefícios objetivos que são percebidos na sua saúde.

A gente vive hoje de um jeito que as pessoas dão muito valor pra voltar a ter um peito bonito, voltar a ter um corpo bonito. E na verdade, a mãe emagrece mais rápido ainda se ela estiver amamentando. E6

O doutor falou assim: 'Olha mãe, você amamenta seu filho, porque enquanto ele estiver mamando, o teu útero vai desinchar mais rápido.' E6

O lado bom da amamentação é assim composto por várias facetas, além dos atributos concretos do leite materno. Compõe-se com a satisfação e prazer das mulheres em amamentar, com a percepção de seu protagonismo exclusivo na alimentação da criança por meio da produção do leite, quando se veem capazes de saciar a fome do filho e ser responsáveis pelo resultado que testemunham do bom desenvolvimento e crescimento da criança.

É um prazer indescritível quando você tá com a mama cheia de leite e a criança tá com fome e você coloca a criança pra 
mamar e ela suga teu leite e você vê que em 10 minutinhos ela tá com a barriguinha cheia de leite e satisfeita, porque mamou. E6

Esse conjunto de elementos converge para uma percepção ampla do processo de amamentar, que, tecido pelas experiências interacionais com o filho - que o processo de amamentar proporciona, em estreita relação com a criança —, projeta nessa experiência a oportunidade de construção de vínculo entre ambos.

É uma experiência única... quem amamenta sabe, não tem o que falar. Você cria uma relação com seu filho que só você pode ter essa relação, mais ninguém, ninguém pode fazer mais por ele do que você. E20

Com base nos conhecimentos de seu universo consensual e valendo-se de conhecimentos ou informações do universo reificado, transmitidos por muitas vias de comunicação, as mulheres conjugam valores, crenças e percepções pessoais desse processo.

Eu penso assim, quanto que a amamentação é importante... Se colocasse numa escala... a minha grande expectativa com o bebê já no colo seria amamentar, porque eu sei da importância da amamentação. E3

A integração cognitiva de saberes e a experiência real de amamentar dão significado e utilidade ao seu conhecimento anterior sobre as vantagens do aleitamento materno, vinculando o conhecimento adquirido e incorporando-o à sua própria rede de categorias, o que pode influenciar a maneira como elas percebem a sua própria experiência de amamentar.

Eu não só gosto de amamentar como eu acho que, se eu tenho, não tem por que tirar ela do peito e dar um leite industrializado, sendo que o meu está aqui. E25 


\subsection{Os desafios da amamentação}

Vivenciar a amamentação representa também vencer desafios que estão objetivados nas dificuldades resultantes das intercorrências mamárias, desconfortos causados pelas mamas cheias ou cansaço do processo contínuo de atendimento das demandas da criança e de outros atores de seu entorno, o que por vezes torna as mulheres inseguras de sua capacidade de superação.

Eu tive mastite. Aí eu fico pensando, bom, apesar de todas as dificuldades, das dores e tal ... E3

Eu acho que passei os piores desafios, porque minha mama rachou, eu tive mastite, eu tive muito leite, ele desceu muito rápido e eu precisei de um acompanhamento de uma enfermeira. Eu nunca fui uma mãe assim: Ah! Eu nunca senti dor e por isso eu amamento. Não! Eu acho que realmente eu venci! E23

O seu peito tá dolorido no começo porque os primeiros 10, 15 dias são os piores, né? E4

Você acha que não vai dar conta de amamentar. É cansativo, enfim! E3

O despreparo e o desconhecimento sobre a realidade dessa prática e sobre como manejar a amamentação também são elementos significativos no enfrentamento das dificuldades que trouxeram dúvida quanto à continuidade da amamentação, sendo que, na primeira gestação, essas dificuldades se manifestam de maneira mais intensa.

Acho que amamentar não é fácil, principalmente no começo! E6

Eu não tava sabendo dá o mamá! Eu achava que era assim: só colocar o neném no peito e ele ia mamar. Mas não foi! Eu não tinha tido preparo pra isso. E5

A minha primeira experiência de amamentar o meu primeiro filho foi muito difícil. E20 
Para as mulheres com uma segunda ou até mais experiências, a prática de amamentar adquirida e a atribuição de significados em situação semelhante as instrumentalizam para lidarem com a situação desafiadora de maneira diferente, tanto pelos conhecimentos adquiridos em contextos consensual e reificado, em suas experiências anteriores de amamentar, como pela experiência atual, que pode ser acrescida de novos elementos. Conforme o conhecimento se enraíza nas experiências de superação das dificuldades anteriores em relação ao aleitamento materno, elas lidam melhor com as dificuldades que aparecem nas amamentações futuras.

Com o segundo filho foi mais fácil. Mas mesmo assim tive mastite. E20

Atores sociais do universo reificado, representados pelos profissionais que as assistem, são observados de uma posição crítica em relação à sua prática, uma vez que as mulheres esperam deles uma prática coerente com o que ensinam, já que eles têm o conhecimento científico sobre as vantagens do aleitamento materno, mas, na prática, as ações evidenciam a negação ou a não aplicação desse conhecimento. Sentem que a sua crença ou seu conhecimento de senso comum é frágil para se impor diante do discurso profissional.

Ainda assim têm mães que acham que o leite é fraco, inclusive os pediatras passam isso pras mães, muitas vezes, e por mais que você é amiga, você dá algum tipo de orientação, você não tem como impor, porque se o pediatra que é o pediatra falou, elas acabam acreditando muito. E25

A conduta profissional de prescrição precoce de fórmulas lácteas contribui para aumentar a crença de que o leite humano é fraco. Do mesmo modo, quando se oferecem às mães alternativas que não valorizam suas dificuldades na amamentação, elas podem ser facilmente desestimuladas da continuidade desse processo se, nesse momento, não estiverem confiantes para amamentar. 
O médico diz o quanto é importante [amamentar], mas ao mesmo tempo ele te dá uma alternativa muito fácil. Numa hora de dificuldade, você agarra nessa alternativa. Pra mim, isso é o começo do fim. E23

As mulheres desta pesquisa, por um lado, enxergam a amamentação como uma experiência prazerosa e de muita importância para a criança e para elas, por outro, experimentaram o que aqui representam os desafios da amamentação, chegando a ficar divididas entre a sua intenção de amamentar e os obstáculos reais que surgiram durante o processo.

Porque ninguém fala pra gente que a amamentação é difícil, e não se prepara inclusive para os inconvenientes, porque dói, eu tive mastite, dói. Às vezes você pensa em desistir. E3

\subsection{O leite humano é único}

Mesmo tendo vivenciado em seu contexto algum tipo de experiência familiar relacionada à amamentação, as experiências dessas mulheres são únicas e as surpreendem, em especial, diante dos resultados que observam e avaliam quanto ao desenvolvimento e crescimento de seu filho.

Eu acho que é um alimento tão singular, tão único que a gente tem pra oferecer pra criança. E6

Mas é muito legal você pensar que seu bebê está crescendo com seu leite, não é? E5

Gente! Ela só toma o meu leite! E1

Nessa perspectiva, o leite materno, para ser melhor compreendido do ponto de vista de seu efeito e propriedades, passa a ser comparado com elementos conhecidos e facilmente visualizado, em um processo de objetivação e ancoragem nos elementos mais comuns e corriqueiros do universo consensual das mulheres, assumindo simbolicamente a figura de comida, remédios e vacinas em seu poder de prevenção de doenças, entre outras 
figuras e ideias que circulam em seu universo, evidenciando a naturalização e materialização do leite humano no contexto de vida dessas mulheres.

...leite materno é alimento. Eu falo pra mãe que jogar leite fora é a mesma coisa que jogar comida no lixo. Leite materno é uma comida. E8

A cicatrização dele é boa também, porque um coleguinha arranhou ele e ficou bem feio... Em quatro dias tinha caído até a casquinha; não tem nada. E5

Eu amamentei meu filho mais velho até um ano; ele é uma criança que não fica doente! É difícil ficar doente! E8

O leite materno é muito poderoso, porque minha neném só mama o leite. Sustenta. E1

As suas falas revelam uma composição de crenças sobre o leite humano, construídas em seu contexto a partir da veiculação de mensagens do universo reificado, que chegam até elas por diversas fontes. Essa crença que as mulheres demonstram em relação aos atributos do leite influi nas suas atitudes em decidir amamentar.

... eles [os bebês] ficam com imunidade boa. E1

Porque tá completinho... tem água, tem vitamina, gorduras, fatores de proteção, tudo o que a criança precisa. E6

Acreditar que o leite humano é importante para a criança e tem vários atributos capazes de contribuir com a saúde e bem-estar dá sustentação ao processo de amamentar das mulheres, como um estímulo a manter a produção para o filho.

[...] A gente conhecer, saber quão rico é o leite materno, quão valioso ele é. $\mathrm{E} 2$ 
Você vê que a criança desenvolve, tanto numa forma intelectual, emocional, numa questão de saúde também. Meu filho é uma criança muito saudável. Ele tem 2 anos e 9 meses e até hoje nunca precisou tomar um antibiótico. Eu acho que isso é porque ele mamou exclusivamente até 6 meses e depois, até 2 anos e 4 meses. E23

\subsection{Produzir bastante leite, ter o suficiente}

O processo de amamentar também é permeado pela preocupação em relação à sua capacidade de produção de leite em quantidade suficiente para o filho. Quando percebem que têm leite em quantidade suficiente, ou até mais que suficiente, sentem-se confiantes na sua capacidade de prover a alimentação da criança.

Eu sempre tive uma grande preocupação se eu teria leite para amamentar. E eu não tinha essa expectativa que eu tivesse bastante leite. Eu [enfaticamente] tenho bastante leite. E3

Durante a gravidez, ou logo após o parto, elas percebem modificações em seu corpo que apontam para a possibilidade de produzirem leite para seus filhos, e isso as tranquiliza.

Quando eu engravidei, meus seios aumentaram bastante, mas eu não sabia que viria tanto [enfaticamente] leite, mas não fiquei preocupada com isso. E1

Quando ele nasceu, eu tive alta e fui pra casa; a minha apojadura veio na mesma noite e veio num volume enorme. E5

A ideia de produzir bastante leite é construída e adquirida em seus contextos familiares e sociais. Ao perceberem que têm leite e, muitas vezes, em grande quantidade, ficam satisfeitas, sentem-se realizadas. Insistindo no peito e amamentando em livre demanda, percebem que sua produção láctea aumenta ainda mais. 
4 Resultados

Só insisti no peito e isso foi aumentando ainda mais o volume, porque eu sempre amamentei em livre demanda. E5

Elas confirmam, assim, a sua própria capacidade de produzir leite, concretizando a ideia adquirida nas suas realidades compartilhadas de que isso é possível, sentindo-se realizadas quanto a poder ofertar o alimento que seus filhos precisam.

Graças a Deus fui abençoada em ter leite suficiente pra minha filha... E7 


\title{
TEMA 2
}

\author{
Banco de leite humano: local de acolhimento \\ e de aprendizagem
}

2.10 acesso ao Banco de Leite

2.1.1 Como fica sabendo sobre o banco de leite

2.1.2 A Motivação para buscar o banco de leite

\subsection{Local de acolhimento}

\subsection{Local de apoio}

\subsection{Local de aprendizagem}

\subsection{O Reconhecimento do valor do Banco de Leite Humano}

\subsection{Tornar-se parceira do trabalho do Banco de Leite}

Destaca-se neste estudo a relação que as mulheres estabelecem com o serviço do BLH. 0 acesso ao Banco de Leite pode ser facilitado e concretizado por diferentes meios e por motivações igualmente diversas. Neste tema, visualiza-se a aproximação das mulheres com um cenário anteriormente desconhecido por elas, exceto pelas que, de alguma forma, contracenam com os atores lá existentes, em suas funções profissionais. Mas, para a maioria delas, apesar de terem informações, o Banco de Leite passa a ser objetivado e ancorado em suas construções mais concretas, com base num acesso utilitarista, ou seja, pela busca para resoluções de problemas ou pelo desejo de depositar seu leite em local onde possa acreditar no uso adequado e consciente. Nessa experiência o banco passa a ser reconhecido como Local de acolhimento, Local de apoio ou de Aprendizagem. Ademais, o trabalho conjunto com o serviço no seu processo de doação de leite proporciona 0 Reconhecimento do valor do 
Banco de Leite Humano o que as motiva a Tornar-se parceira do trabalho do Banco de Leite, sentindo-se engajadas e parceiras do serviço e de sua causa, fazendo, em especial, a divulgação do serviço.

\subsection{O acesso ao Banco de Leite}

O contato com o serviço e sua inserção, seja para o atendimento de suas demandas, seja com o intuito de engajar-se no processo de doação de leite, pode ocorrer por diferentes vias.

\subsubsection{Como fica sabendo sobre o banco de leite}

A inserção das mulheres no ambiente do Banco de Leite é uma verdadeira descoberta e acontece de maneiras variadas. Atuam para isso informações que elas trazem de suas experiências em seu contexto, a partir de convívio com outras mulheres que utilizaram ou interagiram com o serviço.

Eu acho que tive essa iniciativa porque vi minha cunhada grávida, vi minha prima grávida e as duas doaram [leite] pra ajudar. Elas foram um exemplo pra mim e por isso eu doei. E19

Concorre ainda a iniciativa de outros serviços de alguma forma vinculados ao Banco de Leite, que divulga o seu papel e as informa sobre a possibilidade da doação de leite.

Quando eu estava saindo de alta da maternidade, quando ganhei minha segunda filha, uma freira do hospital me deu um folder que tinha o telefone do banco de leite; me disse que se eu tivesse bastante leite deveria ligar para o banco. E14

Eu fiquei sabendo do banco de leite pelo próprio hospital. E24

Eu ouvi falar do banco de leite no hospital, na Unimed. A gente sabia, sim [da existência do banco], de ver. E a gente sabe que tem gente que precisa [de leite]. E10 
Os meios de comunicação multimídia e divulgações pessoais feitas por parentes ou amigas também representam fontes de acesso ao serviço para essas mulheres.

A gente sempre escuta bastante na mídia que sempre tá pedindo leite para o banco, porque são muitas criancinhas que precisam, né? E16

O meu primeiro contato com o banco de leite foi porque a minha cunhada me falava que ela teve problemas com a amamentação do meu sobrinho e ela precisou do banco de leite e foi muito importante para ela. E15

Eu tenho uma amiga jornalista de rádio e ela explicou que doava leite e eu achei assim muиuиito diferente, falando o mínimo. E22

As divulgações oriundas do universo reificado foram feitas por profissionais de saúde, enfermeiras ou técnicas de enfermagem que atuam nas maternidades onde essas mulheres tiveram seus filhos e por profissionais dos cursos de pré-natal de uma cooperativa médica local.

Eu fiquei sabendo do banco pela Maternidade de CP, só que não me deram o telefone. Aí eu procurei na internet. E28

\subsubsection{A Motivação para buscar o banco de leite}

A procura pelo serviço do BLH pode acontecer, muitas vezes, porque elas próprias estão necessitando de uma assistência, de um apoio no seu processo de amamentar.

Na verdade, a necessidade partiu primeiro de mim, porque minha filha se afogou com os jatos de leite, tava sobrando leite e eu tinha medo da minha filha se afogar novamente, e veio a mastite. E30

Também por sentirem necessidade de doar seu leite excedente e com a intencionalidade de doação. 
Na segunda gravidez, começou a vir um monte de leite e eu falei:

Vou ligar lá [Banco de Leite], já, para eu doar. E4

Muitas vezes, essa iniciativa já traz em seu bojo não apenas uma demanda para si, mas a intenção concreta de direcionar sua ação em prol das crianças prematuras, clientes do BLH.

Como eu tenho muito leite, no comecinho eu tirava e jogava, antes de ficar sabendo da doação. E quando eu fiquei sabendo que o banco de leite vive precisando de leite materno pras criancinhas que são prematuras, daí eu resolvi doar. E12

Enfim, independentemente da justificativa, essas mulheres demonstram uma motivação que as impele a buscar o Banco de Leite para doar.

Meu primeiro contato com o banco de leite foi porque eu estava com dificuldade de tirar o leite e estava com as mamas cheias; meu bebê era prematuro, tava internado na UTI e depois, como o meu leite sempre sobrava, eu sempre doei porque me sensibilizava com os prematuros. E18

\subsection{Local de acolhimento}

$\mathrm{Na}$ procura pelo Banco de Leite, seja por demanda de necessidades geradas pelas intercorrências da amamentação, seja por outras razões, sentem-se acolhidas e valorizadas, representando o serviço como um Local de acolhimento. $O$ atendimento pode ser feito na área física do serviço ou, ainda, no domicílio.

Liguei no banco e fui até lá e fui muito bem recebida. Cheguei lá com muita dor, mas fui muito bem tratada. Nossa! Me senti acolhida, saí de lá muito feliz e muito satisfeita... Eu digo que é um tratamento de rainha. E11

Fui orientada pra ligar no banco que vocês [a equipe] iriam em casa. O banco de leite para mim é um lugar de acolhida. Acolhida é a palavra que mais define [o banco de leite] porque é um 
4 Resultados

momento em que a gente tá mais sensível, então a sensibilidade de vocês pra tratar com a gente [foi muito importante]. E5

Fui bem acolhida nas duas vezes [que doei], porque era a mesma pessoa. $\mathrm{E} 4$

\subsection{Local de apoio}

Essas mulheres também se referem ao Banco de Leite como um Local de apoio. $\mathrm{O}$ apoio pode ser entendido como auxílio, amparo ou ajuda.

Quando, assim, do meu primeiro filho, a mama rachou, o peito ingurgitou, elas estavam aqui todas as semanas. Eu tinha uma enfermeira aqui à minha disposição toda semana. Elas conseguiam me orientar e já foi me aliviando um pouco também. E8

Esse apoio é entendido pelas doadoras como essencial, porque essa fase de suas vidas é considerada muito difícil por se sentirem ainda inexperientes, com dificuldades de lidar com as intercorrências, além da experiência inédita de doação do leite.

Daí eu entrei em contato e vocês, de certa forma, me deram muito apoio, me instruíram como eu deveria fazer pra esse leite ser doado. Esse acompanhamento era contínuo e foi muito importante. E23

Ao entrar em contato com esse contexto, as doadoras percebem suas próprias fragilidades frente aos transtornos pelos quais estão passando e reconhecem que os profissionais lidam com elas e suas demandas de forma profissional e respeitosa. É a ajuda que elas precisam para minimizar esses desconfortos.

[...] o banco de leite para mim é um lugar de apoio... porque é um momento em que a gente tá mais sensível, então a sensibilidade de vocês pra tratar com a gente... a paciência pra dizer pra ter calma, que vai ficar tudo bem. E5

Pra mim o banco de leite foi muito importante, porque quando eu não conseguia tirar sozinha, eu vinha aqui pras meninas me ajudarem. E as meninas me ajudaram muito, porque a gente com 
4 Resultados

aquela dor, não consegue fazer ordenha, porque é uma dor que você mesma não dá conta. E18

Ao receberem um atendimento resolutivo, entendem esse apoio como um caminho de mão dupla onde elas ajudam e são ajudadas também.

Não adianta a gente só falar que doou e a gente fez um bem pra todas as pessoas; a gente é muito bem amparado por vocês também. E30

Um dos aspectos que valoriza o atendimento do serviço, na perspectiva das mulheres deste estudo, centra-se no atendimento domiciliar, que permite a continuidade da doação de leite.

Porque eu liguei pra me informar e daí a funcionária já falou comigo e disse que eles vêm aqui [na casa]... E a facilidade das moças virem em casa toda semana. E9

A experiência positiva com a doação e com o serviço favorece novas iniciativas das mulheres em outras gestações, reincidindo em suas ações por conta de sua familiarização com o serviço, sendo um dos motivos de seu engajamento mais de uma vez.

Na minha primeira semana de amamentação, eu precisei entrar em contato com o banco de leite e eles vieram até mim e me explicaram como eu deveria tirar e guardar meu leite para doar. Eu tive apoio do banco e agradeço por isso, tanto que doei duas vezes: da minha filha que hoje tem 8 anos e do meu filho que agora está com 3 anos. E16

\subsection{Local de aprendizagem}

O Banco de Leite também é representado como um local de aprendizagem, uma vez que o acolhimento às suas demandas se reflete também nas orientações que recebem sobre técnicas e procedimentos que adotam para 0 êxito da amamentação e alívio de seus desconfortos. 
Até quando eu tive dúvidas sobre a própria amamentação da minha filha, eu liguei pro banco e tive orientação de como fazer. E7

Eu produzia muito leite. Elas [funcionárias do banco] conseguiam me orientar. Já foi me aliviando um pouco e esclarecendo as minhas dúvidas que me deixavam insegura. E8

Essas dúvidas fazem com que elas se sintam inseguras, porque percebem que, em seu contexto, são poucas as mulheres com as quais podem dividir seus anseios e inseguranças, mas podem contar com os profissionais para a busca de apoio e conhecimento.

Existem poucas mulheres para trocar informações sobre a amamentação, e os profissionais do banco sabem, entendem disso e me dão segurança de que eu estou fazendo o certo. As dúvidas que ninguém me responde, o pessoal do banco responde. Me esclareceram até como guardar o leite para minha própria filha! E6

Assim é onde examinam seu conhecimento de senso comum, confrontam com a realidade e adicionam elementos do universo reificado, compondo um novo conhecimento sobre a amamentação, que aplicam em suas ações cotidianas.

$E$ as meninas [do banco] me atenderam e me explicaram como fazer, inclusive não usar a concha. E5

O Banco de Leite passa a ser, dessa forma, uma referência para o esclarecimento de dúvidas e atendimento de demandas, sendo um local para onde elas podem se dirigir frente a desafios e dificuldades com a amamentação e doação do leite.

Eu fui tentando tudo o que vocês ensinavam e foi muito bom em todos os sentidos. E30 
4 Resultados

\subsection{O Reconhecimento do valor do Banco de Leite Humano}

A experiência exitosa com o serviço de Banco de Leite sugere o movimento de reconhecimento da importância do trabalho realizado com elas, no atendimento de suas demandas, com particular atenção a cada uma delas.

E a facilidade das moças virem em casa toda semana; às vezes eu não escutava elas me chamarem e elas tinham que voltar. E voltavam! E9

A valorização do serviço torna-se cada vez mais intensa, à medida em que reconhecem a intermediação feita pelo Banco de Leite na captação e distribuição do produto de sua ação de doadora, refletindo nos resultados de promoção de saúde e sobrevida de crianças, às quais elas também se dedicaram.

Eu vi na internet que a taxa de sobrevida dos bebês na UTI aumentou muito depois que o Brasil se organizou com a doação de leite materno, e daí eu entendi a importância e fiquei incentivada [a doar]. E9

Sensibilizadas com isso, tentam incentivar outras mulheres a terem a mesma atitude que elas, tornando-se também doadoras.

Eu tentei convencer várias amigas de que isso [doar], dessa ideia, que era um privilégio e isso também foi meio desafiante. E5

A importância de sua ação e do papel do Banco de Leite como uma parceria materializa-se quando elas visualizam as crianças beneficiadas pelo seu leite e pelo trabalho do serviço, por meio das fotografias ali expostas , objetivando o significado daquele trabalho conjunto, sentindo-se parte do processo de recuperação das crianças.

Lá no banco de leite o que mais me chamou a atenção é que tinha bastante foto de bebês antes e depois dos tratamentos. E eu vi a recuperação deles nas fotos. Tinha foto dos bebês prematuros $e$ 
depois eles com o pai, a mãe, a família, depois de um tempo, já recuperados. Então você vê que é importante mesmo o trabalho do banco de leite. E24

Doar o seu leite significa então uma ação efetiva, sendo o leite adequadamente aproveitado, transformando-se em um fator de motivação para essas mulheres.

Daí, quando eu fiquei grávida, eu falava: se eu tiver leite eu vou doar, com certeza, porque é uma coisa doada que realmente chega ao seu destino, né? Chegava em quem precisava. A gente tava doando e não vai se perder pelo caminho. Chega mesmo em quem precisa! E8

Aliado a isso, elas se veem como um exemplo a ser seguido, percebendo-se valorizadas e desempenhando um papel multiplicador importante para a sociedade. É possível apreender na fala dessas mulheres que a representação social da doação tem um sentido muito maior do que simplesmente doar o que está sobrando.

Eu acho também que a minha atitude está servindo de exemplo... bastante gente vem falar do meu exemplo. E6

[É] bom ter bastante leite. É muito legal pensar que seu bebê está crescendo com seu leite. Imagina então pensar que tem 30 bebês crescendo com seu leite. E5

\subsection{Tornar-se parceira do trabalho do Banco de Leite}

Assim, essas mulheres entendem o sentido de serem doadoras, e o gesto da doação passa a fazer parte do seu mundo. Ao se tornarem doadoras, elas criam vínculo com este serviço, e o vínculo pressupõe um compromisso de colaborar com o Banco de Leite, de se sentir parte dele.

Eu me sinto com o banco como uma filha que mora distante $e$ sempre que pode dá um alô, porque a gente acaba criando um vínculo, né? E14 
Mantendo o vínculo, passam a indicar o Banco de Leite para outras mulheres, muitas vezes antes, quando estas ainda estão em fase gestacional.

E vendo a importância desse trabalho quando tá pra nascer algum filho de alguma amiga eu oriento, eu indico o banco. E15

Também indicam o Banco de Leite quando percebem que outras mulheres precisam de orientação a respeito da amamentação, ou estão com dificuldades para amamentar.

Eu criei esse vínculo com o banco de leite, eu tenho o hábito de sempre orientar que a pessoa procure vocês e, se possivel, doe também, porque vai ter todo o apoio de vocês. E16

Quando tem alguma mãe que eu conheço que tá com alguma dificuldade de amamentar por algum motivo, eu sempre oriento para elas virem no banco. E18

A confiança no serviço também se apresenta quando veem outras mulheres com leite sobrando e não sabem o que fazer; entendem que o Banco Ihes será útil.

Eu continuo ligada ao banco de leite porque quando eu vejo uma mulher amamentando e tem muito leite, eu falo para ela ligar no banco de leite que eles vêm em casa, ensinam e buscam o leite. E19

Para essas mulheres, só informar a existência do serviço não basta. Existe também um compromisso em ajudar o serviço, colaborando na arrecadação de frascos.

Além de indicar o banco para minhas amigas que tiveram bebê, o meu jeito de ajudar hoje o banco é com a arrecadação de frascos, porque uma vez eu quebrei um e sei que cada frasquinho é muito importante. Eu ligo, digo que tenho frascos e o banco vem buscar. E15 
Desse modo, além de doarem seu leite para outros bebês, tornam-se divulgadoras do serviço, captando outras mulheres que estão amamentando, incentivando-as a também serem doadoras.

Toda vez que eu tenho uma amiga ou que vejo alguém que tá com muito leite, eu digo: Vai ao banco de leite, doa o excesso, doa o que tá sobrando porque não vai fazer falta. Toda oportunidade você comenta do banco de leite. E13 


\title{
TEMA 3
}

\author{
Doap o leite materno: dá trabalho \\ e exige compromisso
}

\subsection{Conhecendo histórias de doação}

\subsection{Doar o leite dá trabalho}

\subsection{Doar o leite exige compromisso}

\subsection{Apoio da família é essencial}

\subsection{Modos e técnicas da ordenha do leite}

\subsection{Orgulho de ser produtora e doadora de leite}

O engajamento no processo de doação de leite pode ser familiar para essas mulheres, por meio de vivências ou Conhecendo histórias de doação presentes em seu entorno social. Mesmo imbuídas desse propósito, elas reconhecem que Doar o leite dá trabalho e exige compromisso com o estabelecimento de rotinas específicas para garantir a qualidade do leite ordenhado e manutenção de regularidade de coleta. Para tal, o Apoio da família é essencial, desenvolvem Modos e técnicas da ordenha do leite para se adequarem às suas demandas e recursos, bem como vivem a percepção de que são capazes de produzir o leite para seu filho e para outros filhos, o que resulta no Orgulho de ser produtora e doadora de leite, elemento que as estimula a dar continuidade nesse engajamento social. 
4 Resultados

\subsection{Conhecendo histórias de doação}

Ao refletir sobre ser doadora, algumas mulheres retomam o que trazem do seu contexto, em que, para algumas, especialmente a figura de sua mãe é o exemplo que as mobiliza para essa prática. $O$ aleitamento cruzado, nesse contexto, é considerado uma forma de doação.

Eu lembro da minha infância, minha mãe contando como ela tinha muito leite. Eu sei que quando minha irmã mais nova nasceu, uma vizinha tinha adotado um bebezinho; minha mãe amamentou minha irmã e esse outro bebê por um período, e ela sempre me incentivou: 'Ah! Se você tiver bastante leite, você doa'. Não sei se vem até do exemplo dela, não é? E25

A vivência das mães e de mulheres mais velhas que tiveram êxito na amamentação serve de exemplo, de estímulo, o que também proporciona um apoio constante e consistente para que ela, por sua vez, exerça essa prática, valorizada em seu entorno.

Minha mãe foi um exemplo para mim. Ela me amamentou até mais de dois anos, e meu irmão também mamou bastante. E ela me incentivou a doar e me ajudou muito, mas muito mesmo. porque eu trazia meu leite de outra cidade e estocava na casa dela. Era ela quem entregava o leite para o banco. E27

\subsection{Doar o leite dá trabalho}

A doação do leite demanda uma somatória de procedimentos que devem ser aprendidos pelas doadoras, exigindo higiene para extraí-lo, como a higiene pessoal e do ambiente, cuidados com os frascos e local da refrigeração novos itens que serão incorporados na sua rotina diária, e ela percebe que isso demanda trabalho.

Eu não tinha noção de como dava trabalho... toda hora você tem que ficar lavando, esterilizando o negócio, o coletor, e lava a mão, e tem cuidado com a mama e tem um monte de cuidado a mais que você tem que ter. Então, assim, dá trabalho, né? E4 
4 Resultados

Tem que estar tudo bem limpinho, um ambiente muito estéril. E5

$\mathrm{Na}$ vivência dessas mulheres, o engajamento para a doação exige atenção e adaptação pessoal, que exige também uma disposição efetiva para realizar algo que é mais que ação: é atitude frente a um compromisso assumido.

Quando a gente termina de amamentar e ainda se dispõe a fazer todo o procedimento de higiene, dá trabalho, mas quando você se dispõe a doar, você realmente tem que estar engajada, realmente tem que querer [doar] mesmo e fazer acontecer, porque não é fácil. E23

\subsection{Doar o leite exige compromisso}

A rotina diária de amamentação e demais afazeres é acrescida dos cuidados que a doação demanda. As doadoras compreendem esses cuidados como um compromisso, não só de manter uma continuidade da doação, mas um compromisso com a qualidade do produto a ser ofertado para o serviço de BLH.

Porque antes de dar o mamá pra AL, eu já tirava pra doação; então eu sempre tinha aquele compromisso de levantar mais cedo pra fazer toda higiene, pra preparar todo o material ... E30

Eu me sinto com um compromisso com o banco de leite, porque cada vez que eu conheço um pedacinho mais da realidade dos bebês, eu me sinto mais envolvida, porque é muito necessário! E2

$\mathrm{Na}$ percepção dessas mulheres, o compromisso assumido na doação exige regularidade, disciplina para o cumprimento de uma meta.

É um compromisso; eu sentia como um compromisso, porque eu queria doar. Não é uma coisa, assim, se sobrar eu doo, não. Eu tirava com o objetivo de doar. E25 


\subsection{Apoio da família é essencial}

A doação do leite demanda apoios que se projetam, em especial do núcleo familiar, onde aparece a figura do marido como um dos principais apoios afetivos e instrumental para a mulher, oferecendo apoio no incentivo a manter a amamentação.

Eu cheguei em casa e meu seio tava empedrado demais. Quem mais me ajudou a tirar o leite foi meu marido. Ele tem uma mão inacreditável para retirar o leite. E27

De modo semelhante, há apoio também para a doação, por meio de ajuda objetiva na divisão do cuidado com a criança e parceria em momentos em que a mulher necessita.

Graças a Deus eu tive a ajuda do meu marido, então eu pude ajudar. Meu marido apoiava, apoia, acha importante. Então ele me ajudando, isso [doar] foi possível também. E23

Meu marido sempre apoiou muito, muito, em vários sentidos. Teve uma vez que ele foi lá [no hospital], à noite, para pegar um pote porque os nossos tinham acabado. E30

Você precisa estar naquele tempo, às vezes, até de madrugada, porque a maquininha faz barulho. Se o bebê acordar, meu marido levanta e olha ele enquanto eu acabo de tirar o leite. E2

Ainda outros familiares, ao demonstrar o apoio e valorização para com a atitude dessas mulheres, fornecem estímulo para a continuidade da doação.

Minha mãe ficou comigo os 40 dias e ela me ajudava, ficando com meu bebê enquanto eu tirava o leite. E30

Nessas relações existem intensas trocas que contribuem para as mulheres construírem a sua vivência como doadoras de leite. 
Minha mãe falava: 'Filha, você tem que tirar mesmo, porque é muito leite que você tem, teu peito vai empedrar. Olha, vamos tomar um chazinho'. E28

No conjunto do núcleo familiar, a tônica é a valorização de sua capacidade de ser doadora e produtora de leite materno para suprir as necessidades do filho e de outras crianças.

Eles ajudam. É a família. Eles apoiam, acham legal o fato de doar, né? [Eles perguntam] Você não vai tirar lá? Já deu? A mulher não vai vir pegar os frascos? E4

Do ponto de vista do apoio instrumental, a ajuda prática para as atividades do dia a dia é indispensável para o sucesso da amamentação e da doação.

Então você precisa de apoio assim, da família; precisa pra cuidar do bebê. E2

Então eu tive todo apoio e foi muito tranquilo. Tive apoio da minha família. Durante o dia a minha família está sempre aqui me ajudando. E7

\subsection{Modos e técnicas da ordenha do leite}

Cada doadora encontra a sua maneira de extrair seu leite, seja porque é o modo que mais lhe agrada, seja porque é o que lhe é possível. Assim, aliadas aos saberes reificados que lhes são transmitidos pelos profissionais e àqueles desenvolvidos em seu entorno, de senso comum, as mulheres desenvolvem suas formas de esvaziamento das mamas, buscando manter o padrão de qualidade necessário para a doação.

Pra mim eu não conseguiria fazer a ordenha manual, porque eu não tenho tudo isso de leite. Eu tentei inicialmente e, assim, eu só consegui porque uma amiga me emprestou uma maquininha elétrica. E2 
Eu tirava na bombinha, sempre na bombinha. Às vezes ela mamava num peito e no outro já ia saindo e eu já colocava a bombinha no outro e saía fácil. Ia saindo e não precisava fazer nem muito esforço. E24

Para o desempenho de seu papel, elas buscam alternativas para otimizar seu tempo, conciliando a amamentação e a ordenha para a doação.

Enquanto minha filha mamava de um lado, a bombinha tirava do outro. Então, assim, era uma coisa muito prática, né? E15

Também descobrem modos de facilidade para a ordenha, porém nem sempre disponíveis para o uso.

Eu preferia [ordenhar] com a bombinha, eu achava mais prático, menos dolorido e bem mais rápido. Uma bombinha elétrica, simples. A maquininha não é um gasto, é um investimento. Penso que os bancos de leite deveriam fazer esse investimento para ajudar as mulheres a doar. E27

\subsection{Orgulho de ser produtora e doadora de leite}

Ser doadora também é motivo de orgulho. Esse sentimento tem como base a capacidade de amamentar o filho e ainda produzir leite em quantidade para a doação.

É um orgulho! É até legal a gente falar assim: eu tô até doando leite. É legal isso, entendeu? E4

A produção de leite em quantidade para a doação reflete na sua percepção de quantas crianças podem ser beneficiadas por elas e, ainda, no reconhecimento dos profissionais que com elas compartilham a realização de um propósito comum.

É muito legal! Imagina você pensar que tem 30 bebês crescendo com o seu leite. E5 
Eu também amava ver os potes cheios. Amava! Fotografava! Achava superlegal! Superlegal E5

Às vezes eles [equipe do banco] vinham buscar e tinha bastante [pote de leite]. Aquela alegria toda, era gostoso. Eu sentia orgulho do meu leite. E24

\section{O sentimento de orgulho origina-se da sua condição de} provedoras dos filhos e de outras crianças, que precisa ser registrado, confirmado e reafirmado nos sentimentos provocados pelos atores sociais que as cercam.

E eu sentia muito amor quando olhava aqueles frascos na geladeira. Eu ficava imaginando aqueles bebês recebendo o meu leite, assim como eu via o meu filho recebendo leite. Eu achava isso assim [lindo]. Eu tirei foto da geladeira com os frascos. E13

Teve uma semana que eu enchi seis potes e até tirei foto e botei no álbum. Eu tenho foto junto com os potes porque eu me senti muito orgulhosa, assim. Até o meu marido ficava todo orgulhoso com os potes que eu doava. E21 


\title{
TEMA 4
}

\author{
Ser doadora é compartilhar o que tem \\ e ajudar a quem precisa
}

\subsection{Ser solidário: ajudar quem precisa}

\subsection{Doar é compartilhar o que tem de sobra}

\subsection{Evitar o desperdício}

\subsection{Doar para aliviar as mamas}

\subsection{Vale a pena ser doadora}

\subsection{Doar é multiplicar a sensação de ser mãe}

\subsection{Chegou a hora de parar}

A experiência de ser doadora se compõe de crenças e valores construídos no ambiente familiar, no entorno social das mulheres e na sua postura diante de determinadas dimensões objetivas e subjetivas da vida. No seio familiar ou muito próxima do convívio com outros atores sociais, ela aplica, para sua ação de doar o leite, princípios que parecem estar presentes em sua experiência e em seu entorno. Assim, doar é Ser solidário: ajudar quem precisa e compartilhar o que tem de sobra, seus pertences, e por isso mesmo, capaz de distribuir o que ela é capaz de produzir, como o leite materno. A motivação para doar o leite nasce de sua disponibilidade interna de ajudar, porém ela avalia sua capacidade de produzir leite em quantidade que exceda a demanda de seu filho; diante dessa condição, sua voluntariedade e compromisso social se impõem. Doa também para Evitar desperdício de um bem tão valioso que pode ser útil para mais alguém. Outra motivação vem ao encontro de um benefício para $\mathrm{si}$, quando ela doa para aliviar as mamas do peso do leite residual e, com isso, 
4 Resultados

sente que a doação tem a dupla função de poder beneficiar alguém e a si mesma. Mas o processo a leva a avaliar sua dedicação de tempo e energia para o bem de outrem e conclui que Vale a pena ser doadora. Assim, a doação é gratificante e com essa ação, consegue expandir e multiplicar a sensação de ser mãe. Todavia há um momento certo para concluir seu papel de doadora - quando a produção diminui e, em razão disso, o desmame do filho praticamente define seu papel e tempo de doadora, e ela percebe que Chegou a hora de parar.

\subsection{Ser solidário: ajudar quem precisa}

Manifesta-se nas doadoras uma atitude que revela disposição pessoal em doar de si. Essa atitude é adquirida, aprendida ou apreendida dos valores transmitidos na família, comunidade e exemplos que observa em seu entorno, ao que elas nominam como solidariedade, que representa ajudar quem precisa. Na visão delas, suas atitudes têm um papel social e são coerentes com a realidade na qual estão inseridas e com a qual se relacionam.

O meu pai sempre doou sangue, então, assim, a gente sempre teve essa consciência dessa necessidade. E5

Isso eu acho que é muito familiar mesmo. Desde pequena sempre fui educada, foi muito ensinado de sempre contribuir de alguma forma com alguém, com o mundo, tanto doando coisas, como doando seu tempo. [É experiência familiar] ser cuidadoso com as coisas que você tem, com as coisas que você ganha e com as coisas que você faz pelos outros. E3

Eu falo assim, tem gente que doa brinquedo, tem gente que doa roupa. Eu doo leite materno. E8

Desse modo, na perspectiva dessas mulheres, a doação do leite materno é uma forma de oferecer ajuda ao outro, o que é reforçado pelo cenário de bebês prematuros ou de risco e suas mães, que provoca sentimento de solidariedade nas mães doadoras. 
4 Resultados

Eu doava pra ajudar e agradeço muito a Deus pela abundância de leite que eu tive e por ter conseguido ajudar outras crianças. E23

Porque a gente sabe que tem muita gente que precisa. E as pessoas normalmente não têm noção da necessidade que as outras mães passam, que os bebezinhos estão passando. $\mathrm{E} 4$

As doadoras também se colocam no lugar de mães que, por motivos diversos, não têm condição de amamentar ou ofertar seu próprio leite para o filho, e são sensíveis às condições extremas de saúde das crianças que seriam beneficiadas pelo leite que doam.

[...] me colocar no lugar de outras mães [que não produzem leite]. Passar assim por uma experiência sofrida... Eu me comovo com a situação dessas mães porque eu conheço a realidade dos bebês prematuros, porque tenho uma prima que teve um filho que nasceu com 850 gramas [mais leve que uma caixinha de leite] e porque trabalho no hospital. Sinto compaixão porque também sou mãe e penso que poderia ser comigo. E2

Sua atitude visa, de certa forma, aliviar a dor de outra mãe que, mesmo sendo anônima, cria uma relação de troca, uma vez que elas têm leite suficiente para as duas, ou seja, para os seus próprios filhos e os filhos das outras.

Eu sei que consigo acalmar um pouquinho a dor daquela mãe que não conseguiu amamentar e daí ela sabe que teve uma outra mãe que tinha leite bastante pro seu filho e tem leite ainda prá dividir com o filho dela que ela não teve condições de amamentar. E6

Quando eu vi que tinha muito leite, eu fiquei imaginando o quanto seria frustrante para quem não tivesse leite $e$ o quanto seria importante para as mães que não tivessem esse leite para seus bebês pudessem ter através da doação do leite de outras mulheres. E3

A doação é, assim, um ato de solidariedade, misto de dever para com o outro. 
Se tem algo que pode ser feito, porque eu não vou fazê-lo? Se tem um banco de leite, se tem gente que precisa, se é importante, porque eu não vou doar? Não é uma obrigação; ao mesmo tempo que é um prazer, é também um dever. É como se fosse um dever para com o outro, para com as outras pessoas. E se eu tenho, eu não consigo pensar na possibilidade de não doar, sabe? E3

Doar é um ato de bondade, de fraternidade e de retribuir o que a vida lhes proporciona - ser capaz de produzir leite em quantidade - e, com isso, elas se colocam na condição de alguém que também pode salvar vidas.

A gente tá fazendo um ato de bondade para alguém, ajudando alguém que precisa mesmo. Eu doo porque tem gente que precisa. E8

Eu enxergava assim, como uma forma de retribuição, de gratidão, mas primeiro como uma forma de salvar a vida de um bebezinho. E27

Pra mim é um gesto de amor mesmo e eu penso nas mães que estão passando por essa situação de não ter leite e o bebezinho tá dependendo desse leite até pra sobreviver. E25

Eu fiquei feliz de saber que o meu leite serviu pra outra criança. E26

\subsection{Doar é compartilhar o que tem de sobra}

A doação representa, por conseguinte, uma forma de compartilhar o que têm, significando mais que uma mera doação de objeto ou produto: é dividir e destinar algo de si e de seu filho para outro que também precisa e usufrui de sua oferta.

Como ele [o filho] mama bem intervaladinho e dorme bem, então eu aproveito o da noite e falo: o da noite não é dele; é para doação. E2 
4 Resultados

Não obstante, ao compartilhar o leite materno, elas se dispõem a doar o leite excedente, o leite que sobra, estando em prioridade a satisfação do filho, certa de que o leite que produz é de sua criança, mas que pode ser prazerosamente compartilhado com outras.

[...] muito bom saber que eu estou compartilhando o leite da minha filha com outras pessoas. Então, pra mim, doar o leite dela, pra mim é uma satisfação. E6

[...] é uma alegria compartilhar... uma mamada de um bebê prematuro é tão pouquinho ... E2

Eu tinha bastante leite, meu bebê mamava pouco, aí meu leite tava sobrando, tava derramando, aí resolvi doar. E26

Continuamente avaliam sua produção e a capacidade de seu filho consumir a totalidade do leite produzido, o que Ihes possibilita realizar a doação.

Porque se a nenê não consegue dar conta de tudo, então eu vou doar pras outras criancinhas que não têm. E1

Graças a Deus fui abençoada em ter leite suficiente pras outras crianças. E foi automático pensar em doar. E7

[...] depois de um mês de amamentação comecei ter leite o bastante pra doar. E6

Com a continuidade da amamentação, também as mães podem perceber que mantêm sua capacidade de produção e, mesmo ao incluírem novos alimentos na dieta do filho, permanecem produzindo leite, o que lhes permite doar o leite excedente, que já não será oferecido na fase de desmame de sua criança.

Ela mamava bem. Agora que ela já come papinha, tá comendo fruta, tomando suco, então agora sobra mais leite ainda. E6

Pra mim, ter tido a experiência de ser doadora significa uma palavrinha só: vida [enfaticamente]. Porque através de um ato simples, um excesso que nós temos, né? Na realidade, um dom, um privilégio de termos uma produção mais excessiva e salvar muitos pequeninos que estão em vários hospitais. E14 


\subsection{Evitar o desperdício}

Outro elemento importante que se faz presente na motivação dessas mulheres para doar seu leite é que a doação representa uma forma de evitar o desperdício daquele leite que elas consideram de alto valor nutritivo e com outros atributos. Nessa condição, o senso de desperdício se alia ao senso de ajuda e solidariedade.

Um monte de leite sobrando e eu vou jogar? Não, não vou. Vou doar. Quantos bebês precisam, né? E19

Depois, mesmo eles [os bebês] voltando pra casa, amamentando, eles não davam conta do leite que eu produzia; então eu sempre doei. Eu tinha dó de jogar aquele leite, achava isso inacreditável [que alguém pudesse jogar]. E17

Assim, cientes de que o leite de sua doação tem utilidade e destino certo, elas se engajam no processo de doação.

Porque como eu vi que lá na UTI tinha muito bebê que precisava, imagina você jogar fora uma coisa preciosa dessas, saber que aquele leite salva a vida das crianças, salva a vida de um bebê prematuro. E18

O desperdício de leite materno se compara ao desperdício de outros alimentos e objetos que podem ser aproveitados ou reaproveitados, alinhando-se com o sentido de proteção do ambiente, estando entre as coisas preciosas para a humanidade.

Assim como eu tenho conscientização com o desperdício de alimentos, com o destino dos recicláveis, eu coloco a doação de leite na mesma importância. E3

E daí tendo que, às vezes, desprezar, jogar fora; e aí não entrava na minha cabeça que eu tinha que jogar fora aquele leite, entendeu? E4 
4 Resultados

\subsection{Doar para aliviar as mamas}

Em meio às motivações de cunho subjetivo, de valorização do leite e de ajuda solidária, o engajamento no contexto da doação se faz também por necessidades próprias das nutrizes.

Uma das características das doadoras é a alta produção de leite, mantida mesmo que a criança já não apresente as demandas noturnas. Percebem pelo acúmulo de leite, pelo desconforto de mamas cheias e sensação de dor. Assim, a doação é uma forma de garantir, rotineiramente, o alívio das mamas por meio da retirada do leite residual ou excedente, diminuindo também o risco do aparecimento de intercorrências, como ingurgitamento e mastite.

Mas eu tinha que tirar isso [o leite] de qualquer maneira, porque era uma coisa que chegava a vazar, então não tinha como. E7

A gente tem que dizer que, principalmente no começo, é um alívio pra mãe no sentido de dor, de incômodo. E27

Até chegar um ponto que meu bebê já não acordava de madrugada pra mamar e eu acordava. E eu acordava [de madrugada] porque a mama enchia muito. E5

Ao perceber que têm sobra da sua produção de leite e que o leite excedente pode ser aproveitado, as mulheres sentem que podem engajar-se em um processo de troca, no qual elas se beneficiam e, ao mesmo tempo, beneficiam o outro, significando que, ao ajudar os bebês, elas encontram um sentido para uma rotina que garanta o alívio de suas mamas.

Então é uma via de mão dupla. Eu ajudo alguém e esse ato de doar tá me ajudando também, porque senão a mama vai ingurgitar, a mama vai empedrar. E8

Elas passam a entender que a retirada do excesso de leite das suas mamas funciona como prevenção para a mastite, como alívio para a sensação dolorosa que as mamas cheias ocasionam. 
Porque, senão, ela [a mama] endurece e já forma a mastite. Eu já tive duas mastites. Então eu me organizo: de manhã eu sempre faço minha ordenha, antes de tomar café... durante o dia... à noite... e de madrugada. E na madrugada junta um monte de leite. Eu acordo com muito leite. E6

E amamentar é tão prazeroso, já chega a ser uma coisa prazerosa que tirar o leite não é nada demais, não é nada absurdo. E até alivia a dor algumas vezes, porque o seio está muito cheio, então tem que tirar $\mathrm{E} 7$

Ao sentirem-se beneficiadas e gratificadas pela possibilidade de destinar seu leite para uma causa nobre, o trabalho de ordenha e de guarda do leite torna-se um ato amoroso.

Eu tenho que levantar, amor. Não aguento de peso nas costas, então não tem como dormir com esse peito desse jeito. Aí eu vinha e ligava a televisão, tirava o leite com a maior paciência. Eu vi que pra doar você tem que ter paciência, pra doar você tem que ter amor. E28

Eu gostei. Tô adorando! Eu nunca imaginei que ia ter tanto leite. E12

\subsection{Vale a pena ser doadora}

A experiência de ser doadora, na visão dessas mulheres, é uma forma de sentir que pode ser útil e, ao mesmo tempo, ter uma prazerosa vivência tanto de amamentar seu filho, como de contribuir com a saúde de outras crianças. Apesar do trabalho, é um período vivenciado com prazer.

Então, foi uma época muito gostosa e prazerosa que eu tive e vivi muito bem essa época. E eu tenho saudade. E14

Eu me sinto feliz; eu sinto que estou colaborando de uma forma com alguém. E3

Oh! Doar o leite da minha filha pra mim é uma satisfação. E6 
Primeiro que é muito gratificante poder doar. E4

Sentem-se gratificadas pela experiência e possibilidade de ajudar, colocando-se no lugar de alguém que poderia necessitar da mesma ajuda.

Foi muito gratificante e eu até fico emocionada de falar [choro], mas, assim, foi muito carinho. Eu fazia com muito carinho porque poderia ser eu precisando... Poderia ser minha filha. E16

Desse modo, avaliam sua experiência como positiva para si e para o outro; reconhecem em si o valor de quem pode contribuir de forma diferenciada e se colocam na condição de repetir o feito se houver a oportunidade, uma vez que, em sua avaliação, conclui que doar vale a pena.

Como eu amamentei meus dois filhos, se eu tivesse o terceiro filho eu doaria novamente, porque eu acho que vale a pena. É um ato muito bom. E16

\subsection{Doar é Multiplicar a Sensação de Ser Mãe}

Para essas mulheres, doar seu leite representa uma forma de amamentar outras crianças. Experimentam a emoção de saber ou, algumas vezes, de ter a oportunidade de ver in loco os bebês que recebem seu leite, e sentem que se aproximam dessas crianças e simbolicamente se ligam a elas.

Eu sou muito grata às mães que fizeram a doação [de leite] na época que meu filho precisou. E eu pensava nisso quando fazia minha doação. Eu pensava assim: Gente! Quantos filhos de leite será que eu tenho? E27

Uma vez a minha filha ficou internada e eu fui conhecer a neonatal e foi muito emocionante, porque daí eu sabia que o meu leite ia pra lá e daí eu fui doadora, acho que até os 8 meses. E30

Imbuídas do sentimento de se colocar no lugar de outras mães, também suas falas indicam que assumem uma condição de amamentar outros 
bebês, da mesma forma que amamentam seus filhos. Desse modo, doar o leite excedente representa para elas que estão sendo mães das inúmeras crianças que recebem o seu leite e sentem uma sensação de serem mães de muitos. Essa maternidade ampliada faz com que sintam que, ao doar seu leite, estão amamentando outros "filhos".

Eu tinha uma sensação, toda vez que eu dava mamá pro meu filho e eu tirava o leite, pensando assim: Eu amamentei o meu, tem outro que tá precisando mamar, talvez esteja com fome neste momento, então eu vou tirar, deixar a porçãozinha desse outro bebê reservada. E27

Como eu tinha bastante leite, eu amamentava meu filho, mandava pro banco de leite e ainda dava para a filha prematurinha de uma amiga muito próxima a mim que estava sem leite e ela pegava meu leite, diretamente com vocês. Eu sentia que estava multiplicando a minha sensação de ser mãe. E23

\subsection{Chegou a hora de parar}

Assim como o processo de amamentação chega ao seu limite, no desmame precoce ou oportuno, as doadoras veem o momento em que deverão concluir seu papel nesse processo de doação.

Eu sinto assim, parece que é a mesma sensação quando você vai desmamar o filho. Parece que eu desmamei alguma criança quando eu parei de doar. E25

Avaliam então sua condição de manter ou de concluir o processo, à medida que percebem a diminuição da produção de leite, conforme a demanda do filho,

Eu parei de doar porque meu filho justamente tinha completado 6 meses e aí, sim, eu tive a diminuição mesmo da produção e aí tudo o que eu produzia era pra ele. Meu organismo acabou regulando e eu produzia só para o meu filho. E23 
e, assim, conseguem atender unicamente a necessidade de sua criança,

Eu parei de doar leite quando minha filha estava com 5 para 6 meses; eu voltei a estudar e minha produção diminuiu e o leite dava só pra ela. E15

Quando, por motivos pessoais, a necessidade de interromper a amamentação se faz prioridade,

Do meu primeiro filho, eu parei de doar quando parei de amamentar, ao descobrir que estava grávida; então foi assim, de repente. $\mathrm{E} 20$

ou quando as condições, independentemente de sua vontade, não permitem que mantenham a lactação, mesmo que já não amamentem o filho.

Minha vontade era de continuar [doando], mas como tive que trabalhar, no meu trabalho não deu pra continuar. E26

Dessa forma, deixar de ser doadora também é um processo de ruptura, que pode provocar um sentimento de tristeza.

Daí já foi diminuindo e o dia que eu liguei para as meninas irem buscar o último potinho, que eu não tinha conseguido tirar mais, que eu preparei todo o material pra devolver, foi muito triste, foi triste mesmo. E30 
5 Discussão 
5 Discussão

\subsection{Perfil das Doadoras de leite humano}

Para a manutenção dos estoques de leite humano, é necessário que as equipes dos bancos de leite se mobilizem, periodicamente, para a busca do leite doado nas residências das doadoras, por meio da visita domiciliária. Para isso é necessário que o setor de transportes, do próprio local onde está inserido o BLH, ou o serviço terceirizado responsável pelo transporte do leite, tenha uma organização efetiva que permita a busca diária desse produto nos mais diversos endereços. Há, porém, regulamentações - internas, municipais, estaduais ou federais, dependendo do órgão ao qual o BLH está vinculado - que estabelecem os perímetros e/ou quilometragens a serem feitos. Portanto, é comum, e nesta pesquisa não foi diferente, que os veículos homologados pela Vigilância Sanitária para transportarem o leite humano circulem somente até determinadas distâncias, não muito longe do perímetro urbano do município a que pertence o BLH. Isso justifica a quase totalidade de doadoras serem moradoras da área urbana de Londrina, exceção feita a duas delas: uma de área distrital londrinense e outra de um município vizinho.

Quanto à idade das doadoras, Azema e Callahan (2003) encontraram resultados semelhantes em pesquisa realizada com doadoras de oito BLH da França, cuja média foi de 30,6 anos, variando de 20 a 40 anos, sendo que nesta pesquisa a variação foi de 18 a 44 anos. Pesquisa realizada no mesmo município, em 2005, encontrou idades inferiores, que variaram de 14 a 39 anos (SANTOS et al., 2009). Semelhante resultado também foi encontrado por Alencar e Seidl (2010), em que as mulheres pesquisadas, doadoras de Brasília-DF, tiveram variação das idades de 14 a 33 anos.

Observamos que para $25(83,3 \%)$ mulheres doadoras, o tipo de parto adotado foi a cesariana. Resultados menores, mas também preocupantes, $56 \%, 59,25 \%, 57,4 \%$ e $62,86 \%$ foram encontrados, respectivamente, por Dourado, Genovez e Ichimura (2007), Mitsue (2010), Lourenço, Bardini e Cunha (2012) e por Silva et al. (2015). Esse índice alarmante encontrado nas doadoras de leite desta pesquisa condiz com o resultado do inquérito nacional realizado por 
5 Discussão

Leal et al. (2014), em que foram estudadas 23.940 mulheres em 2011 e 2012, obtendo-se que $52 \%$ desse total de mulheres foram submetidas à cesariana, $46 \%$ delas no setor público. A mesma pesquisa mostra que, no setor privado, tal índice se elevou ainda mais, com $88 \%$ de nascimentos por cesariana, quando o índice determinado pela OMS para partos cirúrgicos é de $15 \%$. Corroborando os dados da pesquisa nacional, das 30 doadoras nesta pesquisa 20 tiveram seus bebês num hospital filantrópico, 16 (80\%) dos quais foram por cesariana. Esse hospital é referência para o norte do Paraná e atende partos de alta complexidade, com 250 a 300 partos/mês.

O hospital público onde este estudo foi realizado atende somente alta complexidade e recebe a maioria das gestações e partos de alto risco do Sistema Único de Saúde (SUS) de Londrina e região. Observa-se que essas mulheres - mães de prematuros ou recém-nascidos com outros tipos de problemas - dificilmente conseguem se tornar doadoras, em razão das dificuldades que enfrentam.

Arslanoglu et al. (2010) destacam que, por diferentes razões, muitas mães de prematuros não conseguem fornecer seu leite para seus bebês durante o período neonatal, ainda que este seja um período extremamente importante para se oferecer esse alimento. Não obstante essas dificuldades, duas $(6,7 \%)$ mulheres que tiveram seus filhos no HUL conseguiram ser doadoras.

A preocupação com o aumento significativo dos índices de cesariana no Brasil já existe há mais de vinte anos entre profissionais da área (FAÚNDES; CECATTI, 1991).

Pesquisa realizada por Domingues et al. (2014) destaca que as mulheres atendidas no setor hospitalar privado tiveram $87,5 \%$ de cesarianas, com aumento da decisão por este tipo de parto no final da gestação, independentemente do diagnóstico de complicações. Tanto no setor privado como no setor público, a proporção de cesarianas foi muito superior ao desejado pelas mulheres pesquisadas, e nessa questão, o setor privado supera significativamente o setor público. 
Seja pelo uso de anestésico e analgésicos interferindo na responsividade da mãe e do bebê, seja pela maior chance de a mãe vir a ser separada do seu bebê, a cesariana pode dificultar que se coloque a criança para mamar na primeira meia hora após o parto — o Passo 4 da Iniciativa Hospital Amigo da Criança (IHAC) —, o que pode interferir de maneira negativa na amamentação (FUNDO DAS NAÇÕES UNIDAS PARA A INFÂNCIA, 2009).

Observou-se a importância do Passo 4 da IHAC na sua relação com o AM em pesquisa realizada com RN distribuídos em dois grupos: o grupo intervenção, em que os RN tiveram contato pele a pele com suas mães imediatamente após o parto, e outro, o grupo controle, em que isso não aconteceu. No grupo intervenção, 60\% delas estavam em AME aos dois meses, enquanto somente $20,0 \%$ dos $\mathrm{RN}$ do grupo controle estavam em AME (VIVANCOS et al., 2008).

De acordo com pesquisa realizada por Boccolini et al. (2008), tanto o início como a duração do AM sofrem influência do parto cesariano, a depender do tipo de anestesia utilizada e também se a cesariana foi eletiva ou em caráter de urgência.

Passanha et al. (2015) referem que a prevalência do Aleitamento Materno Predominante tende a ser maior quanto mais passos da IHAC forem cumpridos, entre eles o Passo 4.

A média de filhos das doadoras desta pesquisa $(1,70)$ condiz com o que acontece hoje nas regiões mais desenvolvidas do Brasil e também em países desenvolvidos ou em desenvolvimento, sendo a última média nacional divulgada, referente a 2015, de 1,72 filho por mulher (INSTITUTO BRASILEIRO DE GEOGRAFIA E ESTATÍSTICA, 2016). Resultado com média de filhos ainda menor $(1,54)$ foi encontrado em pesquisa realizada com 50 doadoras em Taubaté-SP (OLIVEIRA, 2010).

Para Berquó e Cavenaghi (2006), se por um lado a taxa de fecundidade no País mostra para os formuladores de políticas públicas como se preparar para atender a população gerada por esses índices, inclusive pensando 
no seu envelhecimento, por outro, o nível de escolaridade pode interferir na redução do número de filhos, muito provavelmente porque essas mulheres têm maior acesso às informações sobre os meios de controle da natalidade.

Alencar e Seidl (2009) também encontraram dados de baixo número de filhos em pesquisa realizada em Brasília-DF com doadoras de leite quando $20(61,1 \%)$ dessas mulheres tinham somente um filho.

Nesse contexto podemos inferir que, com maiores oportunidades de trabalho, ensino e informação, o estilo de vida das mulheres, e entre elas, as doadoras desta pesquisa, distanciou-se do que era no passado. A maioria das mulheres trabalha fora de casa e, ao pensar em filhos, avaliam o investimento necessário para a sua educação. Além disso, a mulher contemporânea também se coloca como prioridade em diversas atividades específicas para si mesma, e não só para seus filhos, demandando também custo para isso.

Em relação à situação conjugal, a quase totalidade das doadoras possuía companheiros, corroborando os achados de Alencar e Seidl (2009), Colomina et al. (2014), Miranda (2014), Silva (2015) e Soares (2014).

Em revisão integrativa feita por Silva, Santiago e Lamonier (2012), os autores referem que, em várias pesquisas avaliadas, o pai é considerado apoio essencial para o sucesso da mulher que amamenta. Silva et al. (2012) observaram que as mães que informaram que o pai da criança esteve presente na gravidez e/ou parto tiveram maior prevalência de AM nos primeiros meses de vida da criança.

A escolaridade das doadoras participantes desta pesquisa surpreende, porque 17 delas $(56,7 \%)$ tinham pós-graduação, e outras $9(30 \%)$ tinham Educação Superior completa. Se somarmos essas duas categorias, teremos 26 doadoras (86,7\%) com Educação Superior completa. Estudo realizado por Colomina et al. (2014) apontou que $65,3 \%$ de mulheres doadoras possuíam formação universitária. Já Galvão, Vasconcelos e Paiva (2006) encontraram que, das doadoras que fizeram parte de seu estudo, somente 9,1\% tinham Educação Superior completa e, quanto ao perfil do grau de instrução das doadoras de Ouro 
Preto, Minas Gerais, estudadas por Miranda (2014), 91,7\% completaram o Ensino Médio.

Alguns trabalhos têm destacado que existe uma relação de maior tempo de AM com o grau de instrução materna, porque, muito provavelmente, mulheres com maior escolaridade têm maior possibilidade de acesso às informações sobre a importância e as vantagens do AM (ESCOBAR et al., 2002; FALEIROS; TREZZA; CARANDINA, 2006; VENANCIO et al., 2002).

Em revisão sistemática realizada por Boccolini, Carvalho e Oliveira (2015), encontrou-se associação entre escolaridade materna e AME, com resultados unânimes de que a sua interrupção está associada à baixa escolaridade materna.

Das 30 doadoras participantes desta pesquisa, 23 (76,7\%) exerciam trabalho remunerado fora de casa. Resultados semelhantes foram encontrados por Prado (2009), em que 66,67\% das doadoras trabalhavam fora de casa. Já para Galvão, Vasconcelos e Paiva (2006), 45,5\% das doadoras pesquisadas eram trabalhadoras assalariadas. Achados semelhantes foram obtidos no estudo de Lourenço, Bardini e Cunha, que demonstraram que 55,5\% das doadoras de Tubarão, Santa Catarina, eram assalariadas.

Dentre as 23 doadoras desta pesquisa que desempenhavam diferentes trabalhos remunerados fora de casa, $9(30,0 \%)$ eram profissionais da área da saúde, podendo isso ter facilitado maior acesso às informações relativas tanto sobre a importância do AM como também sobre a doação do seu leite excedente.

Apesar de muitas mulheres considerarem o trabalho um complicador para a manutenção do $\mathrm{AM}$, as mulheres desta pesquisa conseguiram não só amamentar, como também doar seu leite excedente, mesmo exercendo trabalho remunerado fora do lar.

Vezozzo (2006) destaca que, para muitas mulheres trabalhadoras, o desmame se inicia quando elas retornam ao trabalho, apesar de, muitas vezes, terem conseguido estabelecer a amamentação. 
Brasileiro et al. (2012) mostram que mães trabalhadoras que não participaram de um programa de incentivo ao AM e que não tinham intervalo de 30 minutos durante a jornada de trabalho tiveram maior chance de interromper 0 aleitamento antes do $4^{\circ}$ mês.

Para González (2014), a volta ao trabalho após o nascimento de um filho não é motivo para a mulher iniciar o desmame. É possível conciliar o trabalho materno fora de casa com a amamentação, apesar de não ser uma tarefa fácil. Esse autor aponta ainda que existem dados que mostram que, em muitos países, entre eles a Espanha, a duração média do AM é inferior à duração da licença maternidade, não sendo, portanto, o trabalho materno o real motivo para o abandono da amamentação.

Já em pesquisa realizada no Rio de Janeiro, encontrou-se que as maiores prevalências de AM ocorreram com os filhos de mulheres com maior escolaridade e também com aqueles cujas mães não trabalhavam fora de casa (DAMIÃO, 2008).

As doadoras desta pesquisa relatam ter ficado sabendo do BLH de várias maneiras, sendo que $10(33,3 \%)$ delas receberam a informação por profissionais da saúde e $6(20,0 \%)$, pelos meios de comunicação.

Os profissionais de saúde são os que mais diretamente deveriam estabelecer vínculo com a mulher, tanto no seu processo de gestar, como no de amamentar, para que a chance de sucesso nesses processos aumente.

Esses profissionais são considerados elementos fundamentais para que as taxas de AM no Brasil, em especial as taxas de AME, cheguem aos níveis recomendados pela OMS. Para tanto, eles deverão estar preparados, científica e tecnicamente, valorizando os aspectos emocionais, culturais e sociais do apoio à mulher que amamenta (BRASIL, 2015). Por terem contato contínuo e direto com essa cliente, no pré-natal, no parto e no puerpério, são eles os que mais frequentemente prestam assistência ao binômio mãe-bebê.

Outra maneira importante de divulgação do BLH são os meios de comunicação. Colomina et al. (2014), em pesquisa realizada com doadoras de 
5 Discussão

Madri, Espanha, encontraram que 24,2\% das mulheres doadoras conheceram o Banco de Leite pelos meios de comunicação.

Em pesquisas realizadas por Lourenço, Bardini e Cunha (2012) e por Silva (2010), a importância da contribuição da mídia, da divulgação e propaganda foi valorizada pelas mães e considerada um meio de comunicação importante para o aumento no número de doações de leite humano.

O tempo de doação das doadoras deste estudo foi de 1 a 415 dias, sendo que $12(40,0 \%)$ delas conseguiram doar por um período que variou de 3 a 6 meses. O tempo médio de doação foi de 155 dias, valor semelhante ao encontrado por Colamina et al. (2014), que foi de 189 dias.

Em relação ao tempo de $A M$ dessas doadoras, importante destacar que nenhuma amamentou menos do que seis meses. Das 30 doadoras, $15(50,0 \%)$ amamentaram por mais de um ano, sendo que duas o fizeram por mais de dois anos. A mediana do AM nesse grupo de mulheres foi de 338 dias. Esse resultado foi semelhante ao encontrado na última pesquisa nacional sobre a prevalência do AM, que obteve estimativa de duração mediana no Brasil de 341,6 dias (BRASIL, 2009).

\subsection{As REPRESENTAÇÕES DAS DOADORAS DE LEITE HuMANO}

A vivência das doadoras participantes deste estudo demonstra que todas, de alguma forma, apoiam sua perspectiva de amamentação, em uma trajetória pessoal e coletiva, no mínimo familiar, de experiências de amamentação. Essas mulheres que hoje estão amamentando já viram ou ouviram histórias das outras mulheres de suas famílias ou de suas amigas, quando estas amamentaram.

Para Moreira (2011), membros da família, como as mães, avós, primas, e até amigas, são tidos como referências para esta nova mãe, por suas experiências pregressas na amamentação. Porque, além dos laços afetivos, elas vivem o mesmo projeto de vida em épocas diferentes. 
O meio relacional familiar é a mais comum e importante referência para a mãe no processo de amamentar, por ser o mais próximo a ela, e as ações das mulheres da família exercem influências decisivas nesse processo (MÜLLER; SILVA, 2009; ROCHA et al., 2010).

Para analisar a duração do aleitamento materno em duas gerações, Horta et al. (2007) pesquisaram mães adolescentes acompanhadas desde o nascimentos delas. $O$ resultado evidenciou que aquelas que não foram amamentadas tiveram um risco relativo de 1,34 de não amamentar seus filhos quando comparadas às que foram amamentadas.

Para Araújo (2016), as vivências familiares permitem à espécie humana aprender a amamentar. Reforça ainda que o AM é um bem social compartilhado e transgeracional, exigindo dos profissionais maior entendimento dos processos evolutivos de cada família, para melhor apoiar a mulher que amamenta.

As histórias de amamentação que essas mulheres doadoras experienciaram no seu entorno familiar, e depois a sua própria vivência em amamentar, têm o lado bom da amamentação como os benefícios para a mãe e para o bebê, as alegrias e prazeres, mas também trazem os desafios que as mulheres vivem ao amamentar seus filhos. O cansaço, as dificuldades, as dores passados de uma geração para outra também são vivenciados na história de cada família e, depois, na de cada mulher. E esses desafios são encarados de forma diferente, dependendo do olhar e da vivência de cada família, de cada mulher.

Os sentimentos, derivados da experiência da amamentação, fazem parte da construção do significado dessa ação, influindo no seu curso. A interpretação dessa experiência, determinada pelos sentimentos, resulta na percepção da sensação de prazer ou de contrariedade em relação a amamentar (SILVA, 1997, p. 181).

Situação semelhante quanto à contradição de sentimentos vivenciados pela mulher que amamenta entre os benefícios e as dificuldades dessa experiência foi encontrada por Siqueira (2012), ao apreender das falas das 
mulheres pesquisadas que elas se sentiram cansadas com o processo de amamentar. Esse cansaço era proveniente da solicitação constante do filho, do tempo a ser dedicado ao bebê, das exigências ininterruptas que demandam do ser mãe. Percebem ainda que, para amamentar exclusivamente seus filhos, deverão superar todas essas dificuldades.

Nas falas das mulheres pesquisadas por Osório e Queiroz (2007), a amamentação é um processo cansativo, sendo necessário que a equipe de saúde compreenda a situação de cada mulher para ajudá-la no enfrentamento das dificuldades que aparecerem nesse processo.

Boff et al. (2015) destacam a importância do vínculo efetivo entre a puérpera, a família e os profissionais de saúde gerando confiança e segurança para que essa mulher obtenha sucesso no seu processo de amamentar.

Durante a elaboração do constructo do que seja amamentar, as mulheres percebem que o leite materno é único. Ele tem vários benefícios para seus filhos, e elas constroem o seu significado sobre o leite materno e a importância de elas amamentarem ou não os seus filhos, muitas vezes pelo que elas ouvem das histórias da família. Essas mulheres podem, também, tanto produzir bastante leite e ter leite suficiente ou até excedente para seu filho ou mesmo não produzir o tanto que gostariam. Isso pode ter relação com o que elas ouviram da família e pode determinar para cada mulher a concepção do que é ter bastante leite e o que é ter pouco leite; às vezes, o que é pouco leite para uma mulher é muito para outra, cuja mãe não teve leite nenhum.

O leite humano oferecido exclusivamente nos seis primeiros meses de vida da criança é considerado padrão ouro da alimentação infantil. Ele atende as exigências nutricionais e as especificidades da fisiologia do metabolismo da criança por sua melhor digestibilidade, composição química balanceada, ausência de fatores alergênicos, proteção contra infecções, baixo custo, favorecimento da saúde emocional, saúde oral e praticidade (ALMEIDA, 1999). 
Assim como nesta pesquisa, Miranda (2014) obteve das falas das doadoras entrevistadas que o leite humano foi reconhecido por elas como um alimento importante, em razão dos inúmeros benefícios que ele oferece.

Em pesquisa semelhante, mulheres do Nordeste brasileiro que perceberam a importância do seu leite para a saúde do filho e sentiram que sua produção era maior do que ele necessitava também optaram por compartilhar esse alimento com outras crianças (SILVA, 2010).

No contexto da presente pesquisa, nas falas das doadoras, fica claro que elas percebem que têm diferentes acessos ao Banco de Leite. Algumas ouviram falar por profissionais que as atenderam nas maternidades onde tiveram seus bebês, por amigas, outras ouviram propaganda na televisão, outras no jornal e outras são profissionais de saúde que conheciam o Banco de Leite.

Quando Moscovici (2015) diz que as representações são variáveis independentes que determinam tanto a forma como o estímulo é percebido quanto a resposta que o indivíduo fornece diante da situação e, ao relacionar essa premissa ao tema de estudo deste trabalho, nota-se que as representações sociais determinam o modo como as mulheres recebem as informações dos profissionais que atuam nos BLH sobre o processo da doação, bem como a forma que reagem a essa abordagem. Assim, o desejo de se tornarem doadoras e a receptividade das mães dependerão dos conceitos e das imagens que atribuem a tal prática e de como se enxergam enquanto doadoras.

Oliveira (2010) também encontrou em sua pesquisa que a informação das doadoras sobre o serviço do BLH foi transmitida por profissionais dos hospitais onde foram atendidas, sendo que esses locais são estratégicos para aumentar a captação de doadoras e, consequentemente, das doações de leite.

Em pesquisas com doadoras de Minas Gerais e Pernambuco, assim como nesta pesquisa, observou-se que muitas delas só tiveram conhecimento do Banco de Leite no período após o parto, em geral pelos profissionais das maternidades (MIRANDA, 2014; SILVA, 2010). 
A importância da contribuição da mídia, com divulgação e propaganda, tem sido valorizada pelas mães, sendo considerado um meio de comunicação importante para o aumento do número de doações de leite humano (LOURENÇO; BARDINI; CUNHA, 2012; SILVA, 2010).

Chama atenção que, nesta pesquisa, não emergiu nenhuma fala sobre a divulgação de a informação sobre o Banco de Leite ter sido transmitida pelos profissionais da atenção básica que atendem essas mulheres no pré-natal. Dado semelhante se obteve em pesquisa com doadoras de Ouro Preto-MG, em que ela também relataram ter recebido pouco ou quase nada de estímulo ou apoio para a doação de leite no período do pré-natal (MIRANDA, 2014).

Para Coelho e Jorge (2009), se o trabalho em uma Unidade Básica de Saúde for somente individualizado e as informações não forem prestadas aos trabalhadores, estes, por sua vez, não vão transmiti-las aos usuários, sendo que esses são os que mais sofrem pela falta de comunicação, a exemplo do que ocorreu com as doadoras desta pesquisa.

Diferentemente desse achado, mais de $30,0 \%$ das doadoras de Uberaba-MG pesquisadas por Machado et al. (2013) receberam suas orientações a respeito da doação no pré-natal da rede pública e privada.

O período do pré-natal é um tempo muito propício para os profissionais da saúde abordarem conteúdos relativos à saúde materno-infantil nesse período de espera, quando a mulher se encontra receptiva às orientações fornecidas e pode ser abordada a possibilidade da doação do leite para o banco, caso ela perceba que produza mais leite do que seu filho necessita.

Apesar de algumas receberem a informação sobre a doação do leite, só procura o Banco de Leite a mulher que se sente motivada para efetivar seu desejo de doar. As motivações para essa busca podem ser as mesmas ou diferentes para cada mulher; algumas trazem da experiência familiar a noção de solidariedade, de doar para o outro o que ela tem de sobra por pensar na questão ecológica, para não ter desperdício. Esses são alguns motivos que emergiram de 
suas falas para justificar a sua motivação para procurar o Banco de Leite e dar um uso ao leite excedente que têm.

Para Moscovici (2015), o indivíduo ou grupo busca informações que Ihes permitam entender e explicar as causas que os mobilizam para uma dada ação. Esse movimento, no que diz respeito à ação de doar o leite, pode ser evidenciado neste estudo pelo interesse das mães em adquirir informações com profissionais de saúde sobre o processo de doação de leite e assim construir as representações partindo de uma análise ampliada das motivações de outras mães que vivenciaram essa experiência, conciliando os saberes de senso comum e do universo reificado.

$\mathrm{Na}$ fala dessas mulheres, é possível apreender o que significa o Banco de Leite para elas. Para muitas, é um local de acolhimento, onde elas se sentem acolhidas e não julgadas.

Quando ela se refere ao acolhimento recebido, significa a maneira como foi recebida, recepcionada, considerada. A maneira humanizada que qualquer indivíduo, neste caso, a doadora, deve ser recebido, principalmente nos serviços de saúde, é o que cria uma relação de confiança e compromisso do profissional, representando o serviço com o usuário (BRASIL, 2010).

Existem muitas definições para o termo acolhimento (BRASIL, 2010; FERREIRA, 2010; NORA; JUNGES, 2013; SILVA; ANDRADE; BOSI, 2014), mas "estar com" parece ser o que expressa a intensidade da palavra e explicita de melhor forma seu significado na visão dessas mulheres, sendo o que a mulher demonstra encontrar no serviço do BLH, quando está passando por dificuldades na amamentação e procura quem a auxilie a superá-las.

Contudo, para o acolhimento, é necessário estabelecer vínculo, atenção, diálogo e escuta sensível; é a responsabilização e respeito, para superar a visão fragmentada e individualizada do usuário, para que ele seja percebido como um sujeito de fato. Na prática dos profissionais, o acolhimento é construir e se aprofundar na dimensão cuidadora e envolver-se com o usuário de forma 
ampla e respeitosa, como forma de humanização e resolutividade da assistência em saúde (NORA; JUNGES, 2013).

No AM, é possível entender o acolhimento como um espaço para uma relação vincular, de escuta e encaminhamento dos problemas maternos $\mathrm{e}$ infantis, promovendo a autonomia e humanização. É considerar as nutrizes de forma integral, conhecer e compreender o processo de amamentação e seus determinantes, para uma atenção integral que alcance as dimensões de sua vida, favorecendo a adesão da mulher à amamentação (FRACOLLI et al., 2003).

Fazer com que a mulher que amamenta e necessita ser atendida sinta-se bem acolhida é o mínimo que o serviço de saúde pode oferecer para ela, que se dispõe a superar as dificuldades e amamentar com sucesso, além de ajudar outros bebês com a sobra do seu leite.

As mulheres também representam o BLH como um local de apoio, onde podem verbalizar as suas dores, os seus medos, as suas preocupações. As doadoras desta pesquisa verbalizaram que necessitaram de apoio para superar as dificuldades que apareceram no processo de amamentar e/ou doar.

Para Rapoport e Piccinini (2006), o ser humano necessita de apoio social durante toda a sua vida, em especial em situações de mudanças e estresse, e o nascimento de um filho é considerado uma dessas situações, principalmente para a mãe. Os mesmos autores destacam que, para as novas mães ou para aquelas consideradas experientes, a rede de apoio social pode minimizar as possíveis situações de estresse que elas vivenciam. A rede de apoio é uma forma de oferecer ajuda, tanto informal, como afetiva e prática para essas mulheres (MATSUKURA; MARTURANO; OISHI, 2002).

De acordo com Müller e Silva (2009) em pesquisa realizada com nutrizes, o apoio que essas mulheres referem necessitar para amamentar está relacionado ao suporte dado pelos integrantes do seu entorno às suas questões de espera física ou emocional.

Os profissionais da saúde, juntamente com os familiares e amigos da mulher que amamenta, fazem parte dessa rede de apoio (RAPOPORT; 
PICCININI, 2006). Precisam, portanto, entender a força que esse gesto tem em relação a diminuir a fragilidade da mulher que se encontra em situação estressante com a amamentação, porque isso pode evitar que ela deixe de amamentar por pressões, cansaço, dor, medos pelos quais está passando.

Além do acolhimento, as mulheres encontram no BLH um local onde aprendem e são apoiadas em suas demandas por desenvolver habilidades e julgamentos sobre seu estado de amamentar e doar o leite. Como um local de aprendizagem, elas são instrumentalizadas para 0 atendimento de suas demandas e necessidades biológicas, e também empoderadas como agentes de uma ação valorizada, a de se tornarem doadoras, e passam a receber a assistência que as aproximam do serviço. A partir de suas experiências e dos conhecimentos de um outro universo, reelaboram suas perspectivas como nutrizes e como doadoras.

Nessa perspectiva, destaca-se a importância do profissional e dos serviços, no papel de oferecer um apoio estrutural e instrumental às mulheres, de maneira que suas visões de mundo possam ser respeitadas e agregadas ao saber científico, que, conciliado com as demandas e expectativas delas, possa oferecer subsídios para a compreensão de fenômenos não familiares ao universo do senso comum das mulheres e, por outro lado, agregue elementos importantes para que elas possam reconhecer suas potencialidades e optar pelas ações que Ihe são significativas. Para além de uma ação ou meramente uma tarefa assumida, a doação de leite permite que a mulher conheça os propósitos e finalidades do BLH, intensificando sua motivação para a doação e reconhecendo um trabalho, cuja importância ela percebe.

A doadora integra-se, assim, em um trabalho e uma proposta de cunho social, tornando-se parceira, ao introjetar em sua vida uma "responsabilidade": a de divulgar o serviço do BLH e incentivar outras mulheres a fazerem parte do grupo de doadoras.

Segundo Lourenço, Bardini e Cunha (2013), a doadora que experimenta satisfação e experiência positiva com o ato de doar, exerce papel 
importante na captação de potenciais doadoras. Diferentemente do que foi encontrado no estudo de Miranda (2014), em que as doadoras não se sentiram corresponsáveis em captar novas doadoras de leite humano, relatando ser essa uma função dos profissionais dos serviços de saúde, em especial do nível básico de atenção.

No engajamento do processo de doação do leite, há o reconhecimento do trabalho extra que este representa em sua rotina diária. Em pesquisa realizada com doadoras, Silva (2010) encontrou que a ordenha do leite é considerada trabalhosa e cansativa em virtude do tempo dedicado. Acrescida ao processo de amamentar o filho, a doação representa uma tarefa a mais, a qual envolve técnicas, cuidados e regularidade de procedimentos que demandam tempo e dedicação.

Outras dificuldades, como a técnica para estabelecer a doação, os cuidados higiênicos sanitários nos procedimentos e a dificuldade em conciliar os cuidados do filho e a ordenha do leite, foram encontrados no estudo de Miranda (2014).

Em vista disso, diante de demandas aumentadas em seu cotidiano, as mulheres expressam que a adesão ao plano de doação se sustenta no compromisso assumido, sendo assim, é evidente a representação da doação como um compromisso assumido com uma causa, com pessoas e com um propósito de ajuda.

Para o cumprimento desse compromisso, como contexto das suas ações, funda-se no apoio familiar e nas representações sociais envolvidas no tecido da amamentação e da doação desse grupo social, sua base de ação. A valorização do princípio de solidariedade, de ajuda ao outro, bem como do significado da amamentação para as crianças tecem uma rede de apoio à mulher, objeto e sujeito desse processo - objeto no sentido de ser a merecedora do apoio e da retaguarda estrutural e instrumental para exercer sua função de nutriz e doadora; sujeito por ser o desempenho de produtora e de pessoa determinada a se dedicar ao compromisso assumido, merecedora do apoio afetivo dos familiares. 
5 Discussão

Silva (2010) considera a família como facilitadora do processo de doação e destaca o apoio social, informação, solicitude e carinho provenientes dos familiares como elementos mantenedores do processo de doar. Assim como nesta pesquisa, o apoio do marido foi fundamental por meio da ajuda nos cuidados com o filho, reforçando e valorizando o papel da mãe na prática do amamentar e doar o leite materno.

$\mathrm{Na}$ esteira da sua determinação de ser doadora, o sentimento de solidariedade e de ajuda ao próximo configura a doação como um ato de solidariedade e de ajuda ao próximo. Como bases de contexto familiar e social, a mulher aplica seus princípios de auxílio e compartilhamento com os que não têm aquilo que ela pode oferecer e entregar.

As representações podem canalizar trocas que têm lugar entre nós e a realidade que nos cerca, além de resgatarem e valorizarem o saber popular, crenças e valores construídos ao longo da vida. Nesse sentido, a ideia de poder doar algo de seu alia-se ao sentido da ajuda, que vai além da doação de objetos e ajuda material ao outro: uma ajuda solidária, de salvação de vidas.

Nota-se, no entanto, que, mesmo movidas por um sentimento altruísta, as mulheres doam o que é excedente, o que sobra, garantindo primeiramente $\mathrm{o}$ atendimento da demanda do filho. Assim, ao terem o leite excedente, e ao sentirem-se penalizadas em desperdiçar um produto tão valioso, as mulheres são movidas pelo desejo de contribuir para que outras crianças possam ser beneficiadas pelo leite que elas produzem.

Além dos recém-nascidos, as mães dessas crianças são, de certa forma, também acolhidas pelas doadoras, que se encontram em condição de poder fazer por filhos de outras mulheres o que essas mães podem não ter condições de realizar.

Alencar e Seidl (2009) encontraram que o altruísmo foi a representação mais alegada pelas doadoras do seu estudo. Outro motivo bastante reforçado foi o excesso de produção lática gerando desconforto às lactantes pesquisadas. Em pesquisa realizada com 103 doadoras de 8 Bancos de 
Leite da França, entre as diversas razões para essas doadoras doarem seu leite, obteve-se que $42,7 \%$ o fizeram pelo excesso de produção, diante da opção de doá-lo ao invés de descartá-lo; 35,0\% doaram para ajudar os outros e 13,6\% entenderam que a doação seria algo saudável a fazer (AZEMA; CALLAHAN, 2012)

Para as doadoras estudadas por Machado et al. (2013), os motivos alegados para esse gesto foram: excesso de produção, sentimentos de altruísmo e complicações nas mamas. Já em pesquisa realizada em Londrina por Santos et al. (2006), $65,1 \%$ das mulheres se tornaram doadoras por apresentarem dificuldades relacionadas à amamentação, principalmente o ingurgitamento mamário. As demais se tornaram doadoras simplesmente pelo prazer de doar.

Em pesquisa realizada com doadoras do Rio de Janeiro obteve-se que o motivo mais frequente para a mulher se tornar uma doadora é o excesso de produção de leite, que leva ao ingurgitamento mamário, causa de desconforto e dor, fazendo com que essas mulheres procurem atendimento especializado para essa demanda, ocasião em que se tornam doadoras (PELLEGRINE et al., 2014).

As mulheres deste estudo também referiram haver um ganho próprio ao doar o leite: além de evitar desperdícios, doar representa uma via de mão dupla de benefícios, uma vez que muitas delas promovem, juntamente com seus sentimentos mais nobres, a ordenha para alívio das mamas. Resultado semelhante foi encontrado por Galvão, Vasconcelos e Paiva (2006), que identificaram que a alegação mais frequente para a doação foi o ingurgitamento mamário.

Nos resultados deste estudo, destaca-se o reconhecimento das mulheres de que uma das principais motivações e gratificação da doação de seu leite está na concretização, real ou simbólica, de saber que amamentou muitas outras crianças.

Conhecer as unidades onde permanecem as crianças, ou mesmo ver fotografias das crianças receptoras de leite doado, traz para a doadora a 
figura concreta na qual ela pode ancorar e objetivar o mais fiel sentido da doação do leite que ela produziu e construir de forma mais clara e rica a representação dessa doação. Assim a doação representa para essas mulheres, por intermédio de seu leite, ser mãe de muitas crianças, o que nos remete ao significado mais profundo do papel materno para essas mulheres, atrelado ao ato de amamentar. Siqueira ( 2012) encontrou em sua pesquisa que a mulher atribui à amamentação o significado da maternidade, sendo o único cuidado prestado à criança considerado de exclusivo exercício materno.

Doar o leite representa, então, uma real condição de expansão de sua capacidade maternal; é uma forma objetiva e, ao mesmo tempo, simbólica de amamentar outras crianças, mesmo que sejam anônimas.

Não obstante, da mesma forma como doam o leite que é excedente ou quando o filho não mais precisa de todo o volume produzido, observa-se que, para elas, em sua maioria, o tempo de doação coincide com o tempo do desmame. Assim, ao sinal de diminuição do leite e de que sua produção passa a ser suficiente apenas para o filho, há uma desvinculação do compromisso de doação. Da mesma forma, esse rompimento ocorre na iminência de desmame do filho ou de retorno ao trabalho, quando outras prioridades passam a agir em sobreposição à doação.

Assim, a doação não deixa de ser um ato social movido por uma gama de conjunturas sociais determinadas também pela biologia feminina, condicionada ao processo de amamentação do filho. Como tal, é um processo que tem limites e contornos sociais e biológicos, cujo início e fim são determinados pela mulher. 
6 Considerações Finais 
Chegamos aqui "com o trabalbo de muitos, com o trabalbo desse exército de militantes que acreditam que podem transformar a realidade da saúde pública e entendem que os bancos de leite bumano brasileiros são um produto sus-Brasil de exportação"

[JoÃo APRíGIo GuerRa de ALMEIDA, COORDENADOR DA REDE BRASILEIRA DE BLH].

O desenvolvimento desta pesquisa possibilitou-nos conhecer as representações sociais da doação de leite humano para um grupo de mulheres doadoras de uma das unidades da rBLH.

A doadora é o elemento mais importante para a existência dos BLH e, consequentemente, para a existência do alimento que beneficia milhares de recém-nascidos, prioritariamente os prematuros: o leite humano pasteurizado com qualidade certificada.

Entendemos que, para doar, a mulher deverá, antes de tudo, ter sucesso com o seu processo de amamentar, mesmo vivenciando os desafios que a amamentação impõe, e também produzir leite humano em quantidade suficiente para compartilhar com outros bebês além do seu. Parece-nos que, para aumentar esse contingente de mulheres solidárias, a nutriz deverá ser cada vez mais apoiada e assistida pelos profissionais da saúde que a cercam, antes, durante e depois do parto.

Outro apoio relevante e fundamental é o que recebe da sua família, que deverá ser incluída nas ações de orientação dos profissionais da saúde, para que a linguagem sobre a amamentação seja aprendida pelos que constituem o seu entorno. Com essa rede de apoio e participando de um processo de aprendizagem quanto à amamentação, a mulher poderá chegar à 
6 Considerações $F$ inais

compreensão de que o leite humano é um alimento único, insubstituível e, percebendo-se produtora de abundância de leite, poderá vir a ser uma doadora.

A doação de leite humano é um gesto totalmente desvinculado de interesse pessoal de autopromoção ou de retorno financeiro para quem o faz, por ter como exigência legal ser uma ação espontânea e gratuita. Apreender da fala dessas mulheres o que as mobiliza para esta atitude - a doação - poderá agregar novos conceitos e enriquecer os conhecimentos já existentes para os profissionais que atuam nesta área.

Um aspecto merece atenção especial no intuito de reparar vulnerabilidades percebidas no sistema como um todo. Observou-se, por exemplo, que os profissionais da saúde que atendem as mulheres grávidas no pré-natal fazem pouca ou nenhuma divulgação da possibilidade de elas doarem seu leite após o parto - mesmo havendo, desde 2012, uma política nacional de saúde pública que visa capacitar todos os profissionais da Rede de Atenção Básica do país nos temas aleitamento materno e alimentação complementar saudável, com a Estratégia Amamenta e Alimenta Brasil.

Anualmente o Ministério da Saúde distribui material informativo para todas as Secretarias de Saúde municipais e estaduais e para toda a rBLH, tanto na Semana Mundial de Aleitamento Materno, como no Dia Mundial de Doação de Leite Humano.

Entretanto isso não tem assegurado que as mulheres saibam que poderão vir a tornar-se doadoras. Organizar uma estratégia para incluir a abordagem das mulheres no pré-natal para que se tornem futuras doadoras de leite humano é uma proposta possível de ser elaborada e incorporada pela Comissão Nacional de Bancos de Leite Humano e também pelas Secretarias de Saúde dos municípios onde os BLH estão inseridos.

Garantir que as doadoras realmente encontrem nos BLH um local de acolhimento, apoio e aprendizagem pode favorecer, conforme apreendido nesta pesquisa, o vínculo dessas mulheres com o serviço. Isso pode sustentar a repetição do gesto da doação em futuras gestações, como também viabilizar que 
6 Considerações Finais

a divulgação de propaganda positiva do processo de doar aconteça de fato para outras mulheres que poderão substituir aquelas que naturalmente vão deixando de doar.

O orgulho por ser doadora, essa representação depreendida das falas das doadoras, vem ao encontro do atual lema dos profissionais que fazem parte do cenário de trabalho dos BLH do País: "Orgulho de ser rBLH". Interessante constatar que tanto quem faz a doação de algo seu, como quem cuida desse produto e dessa mulher que oferece o leite doado, todos são impulsionados pelo orgulho de fazer parte desse grupo específico, com suas representações próprias, que acredita que isso faz a diferença na vida de milhares de crianças.

Como proposta a ser inserida na política pública de divulgação sobre a importância da doação do leite humano, no cenário nacional e mesmo local, utilizar algumas das representações sociais que emergiram das falas das mulheres, constructos para serem aproveitados em próximas campanhas, como "Doar vale a pena: é ser mãe de muitos", poderá fazer diferença na captação de novas doadoras. A representação das mulheres de que, pelo seu leite doado, elas se sentem mães de outras crianças é um aspecto ainda não utilizado em campanhas anteriores, com possibilidade de forte impacto em novas mulheres que estão amamentando e que sintam o chamado para doar por meio deste novo enfoque na divulgação. 
Referências 
ALENCAR, L. C. E.; SEIDL, E. M. F. Doação de leite humano e apoio social: relatos de mulheres doadoras. Revista Latino-Americana de Enfermagem, Ribeirão Preto, v. 18, n. 3, p. 381-389, 2010. Disponível em:

<http://www.scielo.br/pdf/rlae/v18n3/pt_13.pdf>. Acesso em: 30 jun. 2016.

ALENCAR, L. C. E.; SEIDL, E. M. F. Doação de leite humano: experiência de mulheres doadoras. Revista de Saúde Pública, São Paulo, v. 43, n. 1, p. 70-77, 2009. Disponível em: http://www.scielo.br/pdf/rsp/v43n1/6839.pdf. Acesso em: 20 jun. 2016.

ALENCAR, S. M. S. M. Doadoras e doações. In: BRASIL. Agência Nacional de Vigilância Sanitária. Banco de leite humano: funcionamento, prevenção e controle de riscos. Brasília: ANVISA, 2008. p. 87-91.

ALMEIDA, J. A. G. Amamentação: um híbrido de natureza e cultura. Rio de Janeiro: Fiocruz, 1999.

ALMEIDA, S. G.; DÓREA, J. G. Quality control of banked milk in Brasília, Brazil. Journal of Human Lactation, Charlottesville, v. 22, n. 3, p. 335-339, 2006. Disponível em: http://jhl.sagepub.com/content/22/3/335. Acesso em:15 jul. 2016.

ANDREASSA, N. P.; APRILE, M. M. Mãe doadora de leite humano. In: Banco de leite humano. APRILE, M. da M.; FEFERBAUM, R. Banco de leite humano. São Paulo: Atheneu, 2011. P. 15-18.

ARABI, A. F.; SCHANLER, R. J. Human milk is the only milk for premies in the NICU! Early Human Development, Limerick, v. 89, S51-3, 2013. Suplemento 2. Disponível em: $<$ http://www.sciencedirect.com/science/article/pii/S0378378213001953>. Acesso em: 15 jul. 2016.

ARAÚJO, L. D. S. Abordagem sistêmica na prática do aleitamento materno. Pediatria a Dia, Florianópolis, Ano 16, n. 54, p. 22-25, 2016.

ARAÚJO, L. D. S. Querer poder amamentar: uma questão de representação. Londrina: UEL, 1997.

ARSLANOGLU, S. et al. Donor human milk in preterm infant feeding: evidence and recommendations. Journal of Perinatal Medicine, Berlin, v. 38, n. 4, p. 347351, 2010. Disponível em:

<http://www.pqcnc.org/documents/milkncccdoc/donormilk/PQCNCHMDonorHuma nMilkPretermFeeding.pdf>. Acesso em: 25 ago. 2016.

AUSTRALIAN GOVERNMENT. Department of Health. Donor human milk banking in Australia- Issues and background paper. New Zealand: Australian Government , 2014. Disponível em: <http://www.health.gov.au/internet/main/Publishing.nsf/Content/D94D40B034E00B 29CA257BF0001CAB31/\$File/Donor\%20Human\%20Milk\%20Banking\%20in\%20A ustralia\%20paper\%20(D14-1113484).pdf>. Acesso em: 15 jul. 2016. 
AZEMA, E.; CALLAHAN, S. Breast milk donos in France: a portrait of the typical donor and the utility of milk banking in the French breastfeeding context. Journal of Human Lactation, Charlottesville, v. 19, n. 2, 199-202, 2003. Disponível em: <http://www.ncbi.nlm.nih.gov/pubmed/12744538>. Acesso em: 30 jun. 2016.

BARDIN, L. Análise de conteúdo. Lisboa: Edições 70, 2010.

BERQUO, E.; CAVENAGHI, S. Fecundidade em declínio: breve nota sobre a redução no número médio de filhos por mulher no Brasil. Novos estudos CEBRAP, São Paulo, n. 74, p. 11-15, 2006. Disponível em: <http://www.scielo.br/pdf/nec/n74/29636.pdf>. Acesso em 10 jul. 2016

BOCCOLINI, C. S.; CARVALHO, M. L. de; OLIVEIRA, M. I. C. de. Fatores associados ao aleitamento materno exclusivo nos primeiros seis meses de vida no Brasil: revisão sistemática. Revista de Saúde Pública, São Paulo, 2015; 49: 91; 1-16, 2015.

BOCCOLINI, C. S. et al. Fatores que interferem no tempo entre o nascimento e a primeira mamada. Cad, Saúde Pública, Rio de Janeiro, v. 24, n. 11, p. 26812694, 2008.

BOFF, A. D. G. et al. Aspectos socieconomicos e conhecimento de puérperas sobre o aleitamento materno. Audiololy: Communication Research, São Paulo, v. 20, n. 2, p. 141-45, 2015. Disponível em:

<http://www.scielo.br/pdf/acr/v20n2/2317-6431-acr-20-2-0141.pdf>. Acesso em: 25 ago. 2016

BRASIL. Agência Nacional de Vigilância Sanitária.Banco de leite humano: funcionamento, prevenção e controle de riscos. Brasília: ANVISA, 2008. Disponível em: <http://www.fiocruz.br/redeblh/media/blhanv2008.pdf>. Acesso em: 15 jun. 2016.

BRASIL. Fiocruz. Rede Brasileira de Bancos de Leite Humano. Rede BLH:

Bancos de leite humano no Brasil, 2016. Disponível em:

<http://www.redeblh.fiocruz.br/cgi/cgilua.exe/sys/start.htm?tpl=home >. Acesso em: 30 jul. 2016.

BRASIL. Ministério da Saúde. Agência Nacional de Vigilância Sanitária.

Resolução RDC 171 de 04 de setembro de 2006. Dispõe sobre o regulamento técnico para o funcionamento de banco de leite humano. Brasília, 2006. Disponível em:

<http://bvsms.saude.gov.br/bvs/saudelegis/anvisa/2006/res0171_04_09_2006.htm l>. Acesso em: 15 jul. 2016.

BRASIL. Ministério da Saúde. Instituto Nacional de Alimentação e Nutrição. Secretaria de Programas Especiais. Programa Nacional de Incentivo ao Aleitamento Materno. Normas gerais para bancos de leite humano. Brasília, 1995. Disponível em: <http://www.fiocruz.br/redeblh/media/p322_1988.pdf>. Acesso em: 20 jul. 2016. 
BRASIL. Ministério da Saúde. Secretaria de Assistência à Saúde. Conselho Nacional de Saúde. Programa Nacional de Doenças Sexualmente Transmissíveis. Diretrizes e normas regulamentadoras de pesquisa envolvendo seres humanos. Brasília, 2012. Disponível em: $<$ http://bvsms.saude.gov.br/bvs/publicacoes/norma_pesq_seres_hum.pdf>. Acesso em 15 jul. 2016.

BRASIL. Ministério da Saúde. Secretaria de Atenção à Saúde. Departamento de Atenção Básica. Saúde da criança: Aleitamento materno e alimentação complementar. 2. ed. Brasília: MS, 2015. Cadernos de Atenção Básica, n. 23.

BRASIL. Ministério da Saúde. Secretaria de Atenção à Saúde. Departamento de Ações Programáticas e Estratégicas. II Pesquisa de prevalência de aleitamento materno nas capitais brasileiras e Distrito Federal. Brasília: Ministério da Saúde, 2009 (Série C. Projetos, Programas e Relatórios).

BRASIL. Ministério da Saúde. Datasus. Nascidos vivos - Brasil. Brasilia: MS, 2014a. Disponivel em:

$<$ http://tabnet.datasus.gov.br/cgi/deftohtm.exe?sinasc/cnv/nvuf.def>. >. Acesso em: 30 ago. 2016.

BRASIL. Ministério da Saúde. Datasus. Nascidos vivos - Paraná. Brasilia: MS, 2014b. Disponivel em:

$<$ http://tabnet.datasus.gov.br/cgi/deftohtm.exe?sinasc/cnv/nvPR.def>. Acesso em: 30 ago. 2016.

BRASIL. Ministério da Saúde. Datasus. Nascidos vivos - Londrina. Brasilia: MS, 2014c. Disponivel em:

htpp://tabnet.datasus.gov.br/cgi/tabcgi/exe?sinasc/cnv/nvpr.def

BRASILEIRO, A. A. et al. Amamentação entre filhos de mulheres trabalhadoras.

Revista de Saúde Pública, São Paulo, v. 46, v. 4, p. 642-48, 2012.

CHANTRY, C. J.; HOWARD, C. R.; AUINGER, P. Full breastfeeding duration and associated decrease in respiratory tract infection in US children. Pediatrics, Evanston, v. 117, n. 2, p. 425-432, 2006.

COELHO, M. O.; JORGE, M. S. B. Tecnologia das relações como dispositivo do atendimento humanizado na atenção básica à saúde na perspectiva do acesso, do acolhimento e do vínculo. Ciência e Saúde Coletiva, Rio de Janeiro, v. 14, p. 1523-1531, 2009. Suplemento 1.

COLOMINA, S. G. et al. Perfil das doadoras de bancos de leite humano e a relação com o tempo de doação de leite humano. Anales de Pediatria, Barcelona, v. 80, n. 4, p. 236-241, 2014. 
Referências

DAMIÃO, J. J. Influência da escolaridade e do trabalho maternos no aleitamento materno. Revista Brasileira de Epidemiologia, São Paulo, v. 11, n. 3, p. 442452, 2008. Disponível em: <http://www.scielo.br/pdf/rbepid/v11n3/10.pdf>. Acesso em 15 jul. 2016.

DOMINGUES, R. M. S. M. et al. Processo de decisão pelo tipo de parto no Brasil: da preferência inicial das mulheres à via de parto final. Cadernos Saúde Pública, Rio de janeiro, v. 30, p. 101-116, 2014. Suplemento 1.

DOURADO, V. G.; GENOVEZ, C. B, UCHIMURA, T. T. Estudo das diferenças entre nutrizes internas e externas de um banco de leite humano. Ciências, Cuidado e Saúde, Maringá, v. 6 p. 347-354, 2007. Suplemento 2.

ESCOBAR, A. M. U. et al. Aleitamento materno e condições socioeconômicoculturais: fatores que levam ao desmame precoce. Revista Brasileira de Saúde Materno Infantil, Recife, v. 2, n. 3, p. 253-261, 2002. Disponível em: <http://www.scielo.br/pdf/rbsmi/v2n3/17095.pdf>. Acesso em: 30 jul. 2016.

EUROPEAN MILK BANK ASSOCIATION. Active milk banks; planned milk banks. Milano: EMBA, 2015. Disponivel em:

<http://www.europeanmilkbanking.com/index.html>. Acesso em: 29 ago. 2016.

FALEIROS, F. T. V.; TREZZA, E. M. C.; CARANDINA, L. Aleitamento materno: fatores de influência na sua decisão e duração. Revista de Nutrição, Campinas, v. 19, n. 5, p. 623-630, 2006. Disponível em: <http://dx.doi.org/10.1590/S141552732006000500010>. Acesso em: 20 jul. 2016.

FARR, R. Representações sociais: a teoria e sua história. In: GUARESCHI, P.; JOVCHELOVITCH, S. Textos em representações sociais. 8. ed. Petrópolis, RJ: Vozes, 1995. p. 31-59.

FAÚNDES, A.; CECATTI, J. G. A operação cesárea no Brasil. Incidências, tendências, causas, consequências e proposta de ação. Cadernos de Saúde Pública, Rio de Janeiro, v. 7, n. 2, p. 150-173, 1991.

FERGUSSON, E.; BIBBY, P. A. Predicting future blood donor returns: past behavior intentions and observer effects. Health Psychology, Washington, v. 21, n. 5, p. 513-18, 2002. Disponível em: http://content.apa.org/journals/hea/21/5/513. Acesso em: 30 jul. 2016.

FERREIRA, A. B. H. Dicionário Aurélio básico da língua portuguesa. Rio de Janeiro: Positivo, 2010

FIOCRUZ. Escola Nacional de Saúde Pública Sérgio Arouca. Pesquisa nascer no Brasil. Inquérito nacional sobre o parto e nascimento, Rio de Janeiro, 2014. Disponível em: <http://www6.ensp.fiocruz.br/nascerbrasil/>. Acesso em: 30 jul. 2016. 
FRACOLLI, L. A. et al. A visita domiciliária sob o enfoque do acolhimento e sua interface com a abordagem do desmame precoce no programa de saúde da família: um relato de experiência. Revista Eletrônica de Enfermagem, Goiânia, v. 5, n. 2, p. 68-72, 2003. Disponível em:

<https://www.revistas.ufg.br/fen/article/view/778>. Acesso em: 15 jul. 2016.

FUNDO DAS NAÇÕES UNIDAS PARA A INFÂNCIA (UNICEF). Iniciativa hospital amigo da criança: promovendo e incentivando a amamentação em um hospital amigo da criança. Brasília: Organização Mundial da Saúde; Ministério da Saúde, 2009. Módulo 3. (Série A. Normas e Manuais Técnicos). Disponível em: $<$ http://www.redeblh.fiocruz.br/cgi/cgilua.exe/sys/start.htm?sid=355>. Acesso em: 25 ago. 2016.

FURMAN, L. et al. The effect of maternal milk on neonatal morbidity of very lowbirth-weight infants. Archives of Pediatrics and Adolescent Medicine, Chicago, v. 157, n. 1, p. 66-71, 2003. Disponível em:

<http://archpedi.jamanetwork.com/article.aspx?articleid=481228>. Acesso em: 30 jul. 2016.

GALVÃO, M. T. G.; VASCONCELOS, S. G, PAIVA, S. S. Mulheres doadoras de Leite Humano. Acta Paulista de Enfermagem, São Paulo, v. 19, n. 2, p. 157-161, 2006.

GIUGLIANI, E. R. J. Rede nacional de bancos de leite humano do Brasil: tecnologia para exportar. Jornal de Pediatria, Rio de Janeiro, v. 78, n. 3, p. 183184, 2002. Disponível em: http:// www.scielo.br/pdf/jped/v78n3/v78n3a01.pdf. Acesso em: 15 de jul. 2016.

GONZÁLEZ, C. Manual prático de aleitamento materno. Tradução de Maria Bernardes. São Paulo: Timo, 2014.

HORTA, B. L. et al. Duração da amamentação em duas gerações. Rev Saude Pública, v. 41, n. 11, p. 13-18, 2007.

HORTA, B. L. et al. Evidence of the long-term effects of breastfeeding: systematic reviews and meta-analyses. Geneva: WHO, 2007. Disponível em: http://apps.who.int/iris/bitstream/10665/43623/1/9789241595230_eng.pdf. Acesso em: 30 ago. 2016.

HUMAN MILK BANKING ASSOCIATION OF NORTH AMERICA. HMBANA active milk banks. Fort Worth: Human Milk Banking Association of North America, 2016. Disponivel em: <https://www.hmbana.org/locations>. Acesso em: 29 ago. 2016.

INSTITUTO BRASILEIRO DE GEOGRAFIA E ESTATÍSTICA (IBGE). Estimativa da população residente no Brasil e Unidades da Federação com data da referência em $1^{\circ}$ de julho de 2015. Disponível em:

< http://www.ibge.gov.br/home/estatistica/populacao/estimativa2015/estimativa_do u.shtm>. Acesso em: 25 ago. 2016. 
Referências

INSTITUTO BRASILEIRO DE GEOGRAFIA E ESTATÍSTICA (IBGE). População: taxas de fecundidade total. 2016. Disponível em:

$<$ http://brasilemsintese.ibge.gov.br/populacao/taxas-de-fecundidade-total.html>.

Acesso em: 30 jul. 2016.

JODELET, D. Representações sociais: um domínio em expansão. In: JODELET, D. As representações sociais. Rio de Janeiro: EdUERJ, 2001. p. 17-44.

JOVCHELOVITCH, S. Vivendo a vida com os outros: intersubjetividade, espaço público e representações sociais. In: GUARESCHI, P.; JOVCHELOVITCH, S. Textos em representações sociais. 8. ed. Petrópolis, RJ: Vozes, 1995. p. 63-85.

KRAMER, M. S. et al. Promotion of breastfeeding intervention trial (PROBIT) - a randomised trial in the Republic of Belarus. Journal of the American Medical Association, Chicago, v. 285, n, 4, p. 413-420, 2001.

KUMMER, S. C. et al. Evolução do padrão de aleitamento materno. Revista de Saúde Pública, São Paulo, v. 34, n. 2, p. 143-148, 2000.

LEAL, M. C. et al. Intervenções obstétricas durante o trabalho de parto e parto em mulheres brasileiras de risco habitual. Cad. de Saúde Pública, Rio de Janeiro, v. 30,S17-S47, 2014. Suplemento 1. Disponível em: http://www.scielo.br/scielo.php?script=sci_arttext\&pid=S0102311X2014001300005\&lng=pt\&nrm=iso\&tIng=pt. Acesso em: 15 jun. 2016.

LOURENÇO, D.; BARDINI, G.; CUNHA, L. Perfil das doadoras do banco de leite humano do Hospital Nossa Senhora da Conceição, Tubarão/SC. Arquivos

Catarinenses de Medicina, Florianópolis, v. 41, n. 1, p. 22-27, 2012.

MAIA, P. R. S, et al. Rede nacional de bancos de leite humano: gênese e evolução. Revista Brasileira de Saúde Materno Infantil, Recife, v. 6, n. 3. p. 285-292, 2006. Disponível em: http://www.scielo.br/pdf/rbsmi/v6n3/31899.pdf. Acesso em: 15 jun. 2016.

MACHADO, M. O. F. et al. Caracterização de nutrizes doadoras de um banco de leite humano. Cienc Cuid Saude, v. 12, n. 3, p. 529-538, 2013. Disponível em: http://www.periodicos.uem.br/ojs/index.php/CiencCuidSaude/article/viewFile/1819 2/pdf

MATTAR, M. J. G. Organização do banco de leite humano. In: APRILE, M. M.; FEFERBAUM, R. Banco de leite Humano. São Paulo: Atheneu, 2011. p. 87-91.

MATSUKURA, T. S.; MARTURANO, E. M.; OISHI, J. O questionário de suporte social (SSQ): estudos da adaptação para o português. Rev Latino-am

Enfermagem, v. 10, n. 5, p. 675-81, 2002. 
MINAYO, M. C. S. O desafio do conhecimento: pesquisa qualitativa em saúde. 3. ed. São Paulo: HUCITEC, 1994.

MIRANDA, W. D. Representações de mães doadoras e de profissionais da atenção básica à saúde sobre a doação de leite humano. 2014. $113 \mathrm{f}$. Dissertação (Mestrado) - Universidade Federal de Ouro Preto, Ouro Preto, 2014.

MITSUE, S. C. Perfil sócio-econômico e ambiental de doadoras de um banco de leite humano no Vale do Paraíba, SP e a qualidade sanitária do leite ordenhado. 2010. 78 f. Dissertação. Universidade de Taubaté, Taubaté, 2010.

MOREIRA, M. A. Continuidades e descontinuidades intergeracionais sobre a experiência de amamentar: um estudo de representações sociais. Tese (Doutorado em Enfermagem) - Escola de Enfermagem. Universidade Federal da Bahia, Salvador, 2011.

MOREIRA, M. A. Continuidades e descontinuidades intergeracionais sobre a experiência de amamentar: um estudo de representações sociais. Tese (Doutorado em Enfermagem) - Escola de Enfermagem. Universidade Federal da Bahia, Salvador, 2011.

MORROW, A. L. et al. Human-milk glycans that inhibit pathogen binding protect breast-feeding infants against infectious diarrhea. Journal of Nutrition, Rockville, v. $135, \quad$ n. $5, \quad$ p. 1304-1307, $2005 . \quad$ Disponível em: http://www.ncbi.nlm.nih.gov/pubmed/15867329. Acesso em: 30 jun. 2016.

MOSCOVICI S. Representações sociais: investigações em psicologia social. 11. ed. Petrópolis: Vozes, 2015.

MOSCOVICI, S. Das representações coletivas às representações sociais: elementos para uma história. In: JODELET, D. As representações sociais. Rio de Janeiro, RJ: EdUERJ. 2001. p. 45-66.

MÜLLER, F. S; SILVA, I. A. Representações sociais de um grupo de mulheres/nutrizes sobre apoio à amamentação. Revista Latino-Americana de Enfermagem, Ribeirão Preto, v. 17, n. 5, 2009. Disponível em: <http://www.scielo.br/pdf/rlae/v17n5/pt_09.pdf>. Acesso em: 10 jul. 2016.

MUSSI-PINHATA, M. M.; REGO, M. A. C. Particularidades imunológicas do prétermo extremo: um desafio para a prevenção da sepse hospitalar. Journal de Pediatria (Rio de Janeiro), v. 81, S59-68, 2005. Suplemento 1. Disponível em: http://www.scielo.br/pdf/jped/v81n1s1/v81n1s1a08.pdf. Acesso em: 30 jun. 2016.

NEWBURG, D. S. Neonatal protection by an innate immune system of human milk consisting of oligosaccharides and glycans. Journal of Animal Science, Champaign, v. 87, n. 13, p. S26-34, 2009, Suplemento. Disponível em: http://www.ncbi.nlm.nih.gov/pubmed/19028867. Acesso em: 30 jul. 2016. 
NORA, C. R. D.; JUNGES, J. R. Política de humanização na atenção básica: revisão sistemática. Revista de Saúde Pública, São Paulo, v. 47, n. 6, p. 11861200, 2013. Disponível em: <http://www.scielo.br/pdf/rsp/v47n6/0034-8910-rsp-4706-01186.pdf>. Acesso em: 30 jul. 2016.

NOVAK, F. R, Colostro humano: fonte natural de probióticos? Jornal de Pediatria (Rio de Janeiro), v. 77, v. 4, p. 265-270, 2001. Disponível em: http://www.scielo.br/pdf/jped/v77n4/v77n4a07.pdf. Acesso em: 30 jul. 2016.

ODDY, W. et al. Association between breastfeeding and asthma in 6 year old children: findings of a prospective birth cohort study. British Medical Journal, London, v. 319, n. 7213, p. 815-819, 1999.

OLIVEIRA, J. S. M. Percepções das doadoras de leite humano sobre doação e amamentação e suas características socioeconômicas e demográficas. 2010. Tese (Mestrado em Nutrição) - Universidade de São Paulo, 2010.

OLIVEIRA, M. M. B. et al. Feeding patterns of Brazilian preterm infants during the first 6 months of life, Londrina, PR, Brasil. Journal of Human Lactation, Charlottesville, v. 23(3):269-74, 2007. Disponível em: http://jhl.sagepub.com/content/23/3/269.long.

OSÓRIO, C. M.; QUEIROZ, A. B. A. Representações sociais de mulheres sobre a amamentação: teste de associação livre de ideias acerca da interrupção precoce do aleitamento materno exclusivo. Revista Escola Anna Nery Revista de Enfermagem, Rio de Janeiro, v. 11, n. 2, 2007, p. 261-267.

ORGANIZACIÓN PANAMERICANA DE LA SALUD. Estudio de caso. Um modelo de cooperación horizontal: la red iberoamericana de bancos de leche humana (BLH) Espanha; 2011. Disponível em: <http://www.paho.org/sscoop/wpcontent/plugins/form/files/15145109Un_modelo_de_cooperacion_horizontal_BLH. pdf>. Acesso em: 15 jan. 2015.

PARAMASIVAM, K. et al. Human breast milk immunology: a review. International of Journal of Fertility Women's Medicine, Washington, v. 51, n. 5, p. 208-217, 2006. Disponível em: http://www.ncbi.nlm.nih.gov/pubmed/17269587. Acesso em: 15 jul. 2016.

PASSANHA, A. et al. Influência do apoio ao aleitamento materno oferecido pelas maternidades. Revista Saúde Pública, São Paulo, v. 49, p. 85, 2015. Disponível em: <http://www.scielo.br/pdf/rsp/v49/pt_0034-8910-rsp-S003489102015049005354.pdf>. Acesso em: 30 jul. 2016.

PELLEGRINE, J. B. et al. Educação popular em saúde: doação de leite humano em comunidade do Rio de Janeiro, Brasil. Interface Comunicação Saúde Educação, Botucatu, 18 p. 1499-1506, 2014. Suplemento 2. 
Referências

PRADO, M. M. Banco de leite humano do município de Varginha-MG: perfil das doadoras e causas de descarte do leite. 2009. $121 \mathrm{f}$. Dissertação (Mestrado em Ciência dos Alimentos) - Universidade Federal de Lavras, Lavras, 2009.

PROGRAMA IBEROAMERICANO DE BANCOS DE LEITE HUMANO - iberBLH. SECRETARIA GENERAL IBEROAMERICANA. 2015. Disponível em: http://www.iberblh.org/index.php?option=com_content\&view=article\&id=642\&ltemi $d=93$. Acesso em: 30 jul. 2016.

QUIGLEY, M. A. et. al. Formula milk versus donor breast milk for feeding preterm or low birth weight infants (review). 2009. The Cochrane Database of Systematic Reviews, Oxford, v. 17, n. 4, CD002971, 2007. Disponível em: <http://www.thecochranelibrary.com>. Acesso em:15 jul. 2016.

RAISLER, J.; ALEXANDER, C.; O'CAMPO, P. Breast-feeding and infant illness: a dose-response relationship? American Journal of Public Health, Washington, v. 89, n.1. p. 25-30, 1999.

RAPOPORT, A.; PICCININI, C. A. Apoio social e experiência da maternidade. Revista Brasileira de Crescimento e Desenvolvimento Humano, São Paulo, v. 16, n. 1, p. 85-96, 2006.

ROCHA, L. F. Teoria das representações sociais: a ruptura de paradigmas das correntes clássicas das teorias psicológicas. Psicologia Ciência e Profissão, Brasília, 2014, v. 34, n. 1, p. 46-65. Disponível em: <http://www.scielo.br/pdf/pcp/v34n1/v34n1a05.pdf>. Acesso em: 30 jun. 2016.

ROCHA, N. B. et al. $\mathrm{O}$ ato de amamentar: um estudo qualitativo. Physis: Revista de Saúde Coletiva, Rio de Janeiro, v. 20, n. 4, p. 1293-1305, 2010.

RODRIGUES, J. N.; RANGEL, M. A teoria das representações sociais: um esboço sobre um caminho teórico-metodológico no campo da pesquisa em educação. Inter-Ação, Goiânia, v. 38, n. 3, p. 537-554, 2013. Disponível em:< http://www.revistas.ufg.br/index.php/interacao/article/view/19593/15663>. Acesso em: 03 dez. 2015.

ROSSETTO, E. G. O uso da translactação para o aleitamento materno de bebês nascidos muito prematuros: ensaio clínico randomizado. 2011. Tese (Doutorado em Saúde Pública) - Escola de Enfermagem de Ribeirão Preto, Universidade de São Paulo, 2011.Disponível em: $<$ http://www.teses.usp.br/teses/disponiveis/22/22133/tde-16052011165859/en.php>. Acesso em: 15 jul. 2016.

SANTOS, D. T, et al. Perfil das doadoras de leite do banco de leite humano de um hospital universitário. Acta Scientiarum, Health Science, Maringá, v. 31, n. 1, p. 15-21, 2009. Disponível em: http://www.redalyc.org/pdf/3072/307226624003.pdf . Acesso em: 15 jul. 2016. 
SANTOS, M. P. A teoria das representações sociais como referencial didáticometodológico de pesquisa no campo das ciências humanas e sociais aplicadas. Revista Emancipação, v. 13, n. 1, p. 9-21, 2013. Disponível em: $<$ http://dialnet.unirioja.es/servlet/articulo?codigo=5029363 $>$. Acesso em: $03 \mathrm{dez}$. 2015.

SCHANLER, R. J. et al. Randomized trial of donor human milk versus preterm formula as substitutes for mothers'own milk in the feeding of extremely premature infants. Pediatrics, Evanston, v. 116, n. 2, p. 400-406, 2005. Disponível em: <http://www.ncbi.nlm.nih.gov/pubmed/16061595>. Acesso em: 15 jun. 2016.

SCHIELE, B.; BOUCHER, L. A exposição científica: uma maneira de representar a ciência. In: JODELET, D. As representações sociais. Rio de Janeiro, RJ: EdUERJ. 2001. p. 363-378.

SCOCHI, C. G. S. A humanização da assistência hospitalar ao bebê prematuro: bases teóricas para o cuidado de enfermagem. 2000. Tese - Escola de Enfermagem da Universidade de São Paulo,Ribeirão Preto, 2000.

SCOCHI, C. G. S. et al. Incentivando o vínculo mãe-filho em situação de prematuridade: as intervenções de enfermagem no Hospital das Clínicas de Ribeirão Preto. Revista Latino-Americana de Enfermagem, Ribeirão Preto, v.11, n. 4, p. 539-543, $2003 . \quad$ Disponível em: http://www.scielo.br/pdf/rlae/v11n4/v11n4a18.pdf. Acesso em: 30 jun. 2016.

SILVA, B. T.; SANTIAGO, L. B.; LAMONIER, J. A. Apoio paterno ao aleitamento materno: uma revisão integrativa. Revista Paulista de Pediatria, São Paulo, v. 30, v. 1, p. 122-310, 2012.

SILVA, E. S et al. Doação de leite materno ao banco de leite humano: conhecendo a doadora. Demetra: alimentação, nutrição e Saúde, v. 10, n. 4, p. 879-889, 2015. Disponível em: <http://www.epublicacoes.uerj.br/index.php/demetra/article/view/16464\#.V6ncGdQrJkg>. Acesso em: 15 jul. 2016.

SILVA, I. A. Amamentar: uma questão de assumir riscos ou garantir benefícios. São Paulo: Robe, 1997.

SILVA, I. A. Desvendando as faces da amamentação através da pesquisa qualitativa. Revista Brasileira de Enfermagem, Brasília, v. 53, n. 2, p. 241-249, 2000.

SILVA, M. Z. N.; ANDRADE, A. B.; BOSI, M. L. M. Acesso e acolhimento no cuidado pré-natal à luz de experiências de gestantes na atenção básica. Saúde Debate, Rio de Janeiro, v. 38, n. 103, Rio de Janeiro, 2014. 
SILVA, P. P. et al. A percepção das mães sobre o apoio paterno: influência na duração do aleitamento materno. Rev Paul Pediatr, São Paulo, v. 30, n. 3, p. 306-313, 2012.

SILVA, S. E. D.; CAMARGO, B. V.; PADILHA, M. I. A teoria das representações sociais nas pesquisas da enfermagem brasileira. Revista Brasileira de Enfermagem, Brasília, 2011, v. 64, n. 5, p. 947-51, 2011.

SILVA, S. L. Alegações maternas para doação de leite humano. 2010. Dissertação (Mestrado em Saúde da Criança e Adolescente) - Universidade Federal de Pernambuco, Recife, 2010. Disponível em:

<http://repositorio.ufpe.br/handle/123456789/9168>. Acesso em: 20 jun. 2016.

SIQUEIRA, F. P. C. O significado da amamentação na construção da relação mãe e filho: um estudo interacionista simbólico. 2012. Tese (Doutorado em Enfermagem ) - Escola de Enfermagem da Universidade de São Paulo e Escola de Enfermagem de Ribeirão Preto da Universidade de São Paulo, 2012. 142 f. Disponível em: http://www.teses.usp.br/teses/disponiveis/83/83131/tde-22082012110210/pt-br.php

SOARES, I. S. Auto-eficácia em amamentação de doadoras de leite materno Universidade Federal do Piauí, Teresina, 2014.

SPATZ, D. L. Innovations in the provision of human milk and breasteeding for infants requiring intensive care. Journal of Obstetric, Gynecologic, \& Neinatal Nursing, Philadelphia, v. 41, n. 1, p. 139-143, 2012.

STATISTICS Package for the Social Sciences (SPSS). Version 20.0. New York: IBM. Software

SPINK , M. J. Desvendando as teorias implícitas: uma metodologia de análise das representações sociais. In: GUARESCHI, P.; JOVCHELOVITCH, S. Textos em representações sociais. 8. ed. Petrópolis, RJ: Vozes, 1995. p.117-145.

UNICEF. Levels \& Trends in Child Mortality. New York: Unicef, 2015. Disponivel em:

<http://www.childmortality.org/files_v20/download/IGME\%20Report\%202015_9_3 \%20LR\%20Web.pdf>. Acesso em: 29 jul. 2016.

VASQUEZ ROMÁN, S, et al. Puesta en marcha del banco de leche materna donada en una unidad neonatal. Anales de Pediatria (Barcelona), v. 71, n. 4, p. 343-348, 2009. Disponível em: http://www.analesdepediatria.org/es/puestamarcha-del-banco-leche/articulo/S1695403309003610/. Acesso em: 15 jul. 2016. 
VENANCIO, S. I. et al. Frequência e determinantes do aleitamento materno em municípios do Estado de São Paulo. Revista de Saúde Pública, São Paulo, v. 36, n. 3, p. 313-318, 2002.

VENANCIO, S. I. et al. Breastfeeding practice in the Brazilian capital cities and the Federal District: current status and advances. J Pediatr, Rio de Janeiro, v. 86, n. 4, p. 317-324, 2010.

VENANCIO, S. I.; SALDIVA S. R. D. M.; MONTEIRO, C. A.Tendência secular da amamentação no Brasil. Revista de Saúde Pública, São Paulo, v. 47, n. 6 , p.1205-1208, 2013.

VEZOZZO, K. M. K. Amamentação e trabalho da mulher. In: CASTRO, L. M. C. P.; ARAÚJO, L. D. S. Aleitamento materno: manual prático. 2. ed. Londrina: ANS, 2006. cap. 19. p. 159-164.

VICTORA, C. G. et al. Breastfeeding in the 21st century: epidemiology, mechanisms and lifelong effect. The Lancet, London, v. 387, n. 10017, p. 475490, 2016. Disponível em: <http://www.thelancet.com/series/breastfeeding>. Acesso em: 30 jul. 2016.

VIVANCOS, R. B. Z. et al. Alimentação do recém-nascido após alta hospitalar de uma instituição amiga da criança. Acta Paulista de Enfermagem, São Paulo, v. 21, n. 3, p. 439-443, 2008. 
Apêndices 


\section{APÊNDICE A}

\section{Termo de Consentimento Livre e Esclarecido}

Meu nome é Márcia Maria Benevenuto de Oliveira e sou aluna de pós-graduação, nível doutorado, da Escola de Enfermagem da Universidade de São Paulo.

A senhora está sendo convidada a participar da pesquisa "Doação de leite humano: conhecendo a representação social das doadoras", que está sendo orientada pela professora Dra. Isília Aparecida Silva, docente d Escola de Enfermagem da USP, responsável pela condução desta pesquisa.

Este estudo tem como objetivo conhecer as representações sociais das mulheres sobre a doação do leite humano em um hospital universitário público.

Ao concordar em participar da pesquisa, a senhora irá responder perguntas de um questionário, demandando um tempo máximo de 1 (uma) hora. Eu, respeitando a sua disponibilidade de data e hora, conforme agendamento prévio, em sua residência, farei perguntas para você sobre seus dados pessoais e sobre o seu gesto de doação de leite humano e gravarei, com sua permissão, as suas respostas. Elas depois serão transcritas para posterior análise e mantidas em sigilo, guardadas em local seguro, sob a reponsabilidade da professora Dra. Isília Aparecida Silva.

Informo ainda que as informações serão utilizadas somente para os fins desta pesquisa, os resultados deste estudo serão utilizados somente para fins científicos, sem qualquer ganho pessoal ou econômico da pesquisadora e serão tratadas com o mais absoluto sigilo e confidencialidade, de modo a preservar a sua identidade.

Participar da pesquisa não trará nenhum risco à senhora ou ao seu filho. A senhora é livre para decidir em participar ou não do estudo, podendo desistir a qualquer momento, não havendo nenhum tipo de prejuízo na assistência recebida nesse serviço de saúde. Se tiver alguma dúvida sobre o estudo, poderá entrar em contato com a Profa. Isilia pelo telefone 30618850, ou 30617602. Pode também procurar o Comitê de Ética em Pesquisa Envolvendo Seres Humanos que funciona no Serviço de Apoio à Pesquisa da Escola de Enfermagem da USP, pelo telefone (11)30617548, ou pelo e-mail: edipesq@usp.br. Pode, ainda, procurar o Comitê de Ética em Pesquisa da Universidade Estadual de Londrina, PR, pelo telefone (43)3371-5455, ou pelo email: cep268@uel.br. 
Este documento possui duas vias, sendo que uma ficará em seu poder e a outra arquivada, sob a responsabilidade da Profa. Dra. Isilia Aparecida Silva.

Eu, declaro que fui esclarecida sobre o estudo, estou ciente dos objetivos e finalidades da pesquisa, e que posso solicitar outras informações e modificar minha decisão, se assim o desejar. Como me considero informada sobre a minha participação, concordo em colaborar, respondendo às perguntas do estudo.

Assinatura da participante da pesquisa

Assinatura do responsável ${ }^{1}$

Assinatura da Pesquisadora

Assinatura da Orientadora

São Paulo de de 2015.

\footnotetext{
${ }^{1}$ A assinatura de um responsável será solicitada no caso da mãe ser menor de 18 anos.
} 
Anexos 


\section{ANExo A \\ Parecer Consubstanciado do Comitê de Ética em Pesquisa (CEP)}

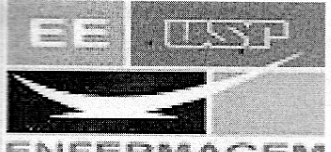

\section{ESCOLA DE ENFERMAGEM DA UNIVERSIDADE DE SÃO PAULO - EEUSP}

\section{PARECER CONSUBSTANCIADO DO CEP}

\section{DADOS DO PROJETO DE PESQUISA}

Título da Pesquisa: A Representação Social de Mulheres Doadoras de Leite Humano Pesquisador: Isilia Aparecida Silva

Área Temática:

Versão: 1

CAAE: 45427515.7 .0000 .5392

Instituição Proponente: Escola de Enfermagem da Universidade de São Paulo - EEUSP

Patrocinador Principal: Financiamento Próprio

\section{DADOS DO PARECER}

Número do Parecer: 1.105 .438

Data da Relatoria: 09/06/2015

Apresentação do Projeto:

"A REPRESENTAÇÃO SOCIAL DE MULHERES DOADORAS DE LEITE HUMANO"

Programa Interunidades de Doutoramento em Enfermagem da Escola de Enfermagem da Universidade de São Paulo - EEUSP.

O propósito deste trabalho é tentar compreender o que está por traz das açōes das mulheres doadoras de leite humano e suas representaçōes sociais sobre a doação do leite humano.

Como o número de doadoras nas últimas décadas aumentou significativamente, refletindo no aumento da oferta de leite humano pasteurizado aos recém-nascidos prematuros e de baixo peso e, consequentemente, na redução da morbimortalidade infantil, em especial, a neonatal, é inquietante e, ao mesmo tempo estimulante, tentar entender o que faz com que essas mulheres optem pelo gesto de doação.

Para os profissionais que trabalham nesta área, tentar entender qual é a mola propulsora que leva a mulher a optar por este gesto solidário, poderá ajudar a aumentar a doação deste alimento vital.

Espera-se que o conhecimento sobre as questōes mais subjetivas e do entorno dessas mulheres

Endereço: Av. Dr Enéas de Carvalho Aguiar, 419

Bairro: Cerqueira Cesar

CEP: $\quad 05.403-000$

UF: SP Município: SAO PAULO

Telefone: (11)3061-7548 Fax: (11)3061-7548

E-mail: edipesq@usp.br 


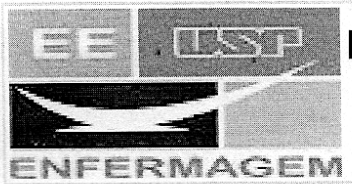

\section{ESCOLA DE ENFERMAGEM DA UNIVERSIDADE DE SÃO PAULO - EEUSP}

Continuação do Parecer: 1.105.438

possa facilitar a ação dos profissionais na abordagem, na proposta de elementos facilitadores e promotores da adesão destas para a doação do leite, de forma espontânea e autônoma, contribuindo para a melhoria de saúde de inúmeras crianças.

Pesquisa de abordagem qualitativa, a ser realizada com as mulheres doadoras de leite humano do Banco de Leite Humano do Hospital Universitário de Londrina.

O número de mulheres participantes não será definido previamente, uma vez que para este estudo será adotado o critério de saturação dos dados. Serão incluídas mulheres que estiverem cadastradas no BLH de Londrina como doadoras ativas, a partir da data estabelecida para o início da pesquisa, conforme cronograma e que aceitarem participar.

As entrevistas ocorrerão nos domicílios das doadoras, após contato telefônico e autorização das mesmas, com uso de aparelho gravador digital, mediante seu consentimento.

Serão obtidos dados sociodemográficos por meio de instrumento estruturado e será feita a entrevista para obtenção dos dados qualitativos, que se iniciará com uma "provocação" sobre o tema: "Gostaria que me falasse como tem sido a sua experiência de doar o seu leite para o BLH."

Outras questões que podem aprofundar o tema sobre a representação,motivação, identificação de elementos do entorno social da mulher para manter sua aderência como doadora serão introduzidas à medida que for necessário, no decorrer da entrevista.

O marcu conceitual será a teoria das representaçõcs sociais de Moscovici

Para a análise dos dados, será utilizado o método de Análise de Conteúdo proposto por Bardin por favorecer a exploração das relações que os indivíduos mantêm em sua vida, o que constrói suas representações sociais.

\section{Objetivo da Pesquisa:}

\section{Objetivos:}

- conhecer as representações sociais das mulheres sobre a doação do leite humano em um hospital universitário público;

Endereço: Av. Dr Enéas de Carvalho Aguiar, 419

Bairro: Cerqueira Cesar

UF: SP Município: SAOPAULO

Telefone: (11)3061-7548 Fax: (11)3061-7548

CEP: $05.403-000$ 


\section{$\equiv \equiv$ ESCOLA DE ENFERMAGEM DA

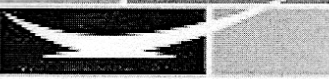 \\ UNIVERSIDADE DE SÃO PAULO - EEUSP \\ ENFERMAGEN}

Continuação do Parecer: 1.105 .438

- relacionar as características biológicas e sociais das mulheres participantes do estudo, com as representações sociais emergidas.

Avaliação dos Riscos e Benefícios:

Riscos:

Constrangimento em falar sobre fatos de sua vida pessoal.

Benefícios:

Desvendar, entre as mulheres participantes deste estudo, o que representa o gesto de doar seu leite a outras crianças, poderá contribuir, no futuro, para melhor planejamento de ações para o incremento de um projeto de captação de leite humano para melhoria de qualidade de vida de crianças em situações de risco, cujas mães não conseguem amamentá-las.

Comentários e Considerações sobre a Pesquisa:

Estudo relevante para a área de atuação.

Considerações sobre os Termos de apresentação obrigatória:

TCLE descrito de forma clara em linguagem acessível.

Recomendações:

Não há.

Conclusões ou Pendências e Lista de Inadequações:

Sem óbices éticos.

Situação do Parecer:

^provado

Necessita Apreciação da CONEP:

Não

Considerações Finais a critério do CEP:

Este CEP informa a necessidade de registro dos resultados parciais e finais na Plataforma Brasil.

Esta aprovação não substitui a autorização da instituição coparticipante, antes do início da coleta de dados.

Endereço: Av. Dr Enéas de Carvalho Aguiar, 419

Bairro: Cerqueira Cesa

UF: SP

Município: SAO PAULO

Telefone: (11)3061-7548

Fax: (11)3061-7548

E-mail: edipesq@usp.br 


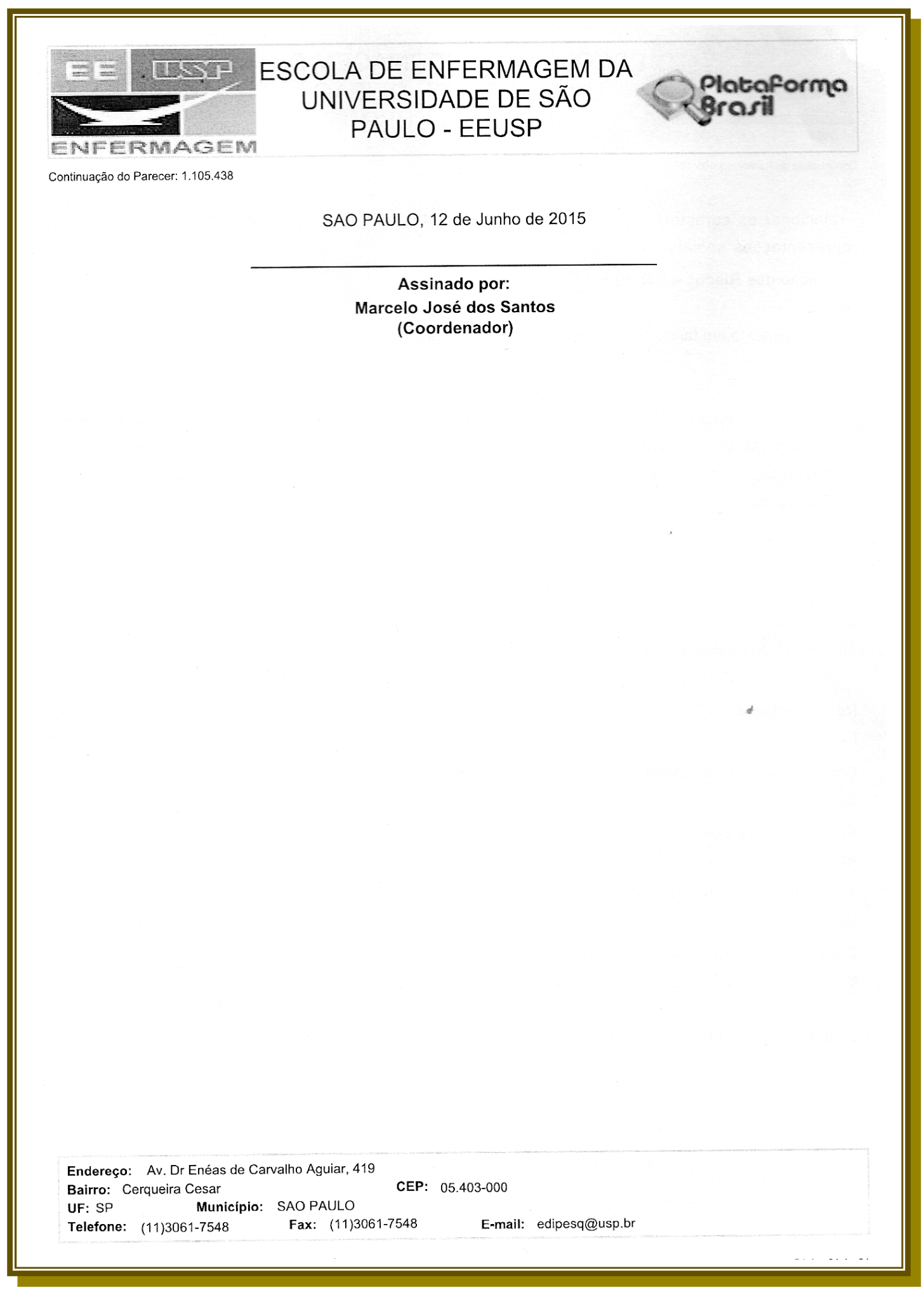




\section{ANEXO B}

\section{PARECER № 102}

\section{Universidade Estadual de Londrina

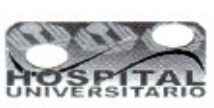 \\ HOSPITAL UNIVERSITÅRIO \\ DIRETORIA SUPERINTENDENTE \\ PARECER N'102 \\ PROCESSO 7448.2015.31}

À Pesquisadora

Isília Aparecida Silva

Considerando o Projeto de Pesquisa com o título " $A$ REPRESENTAÇÃO SOCIAL DE MULHERES DOADORAS DE LEITE HUMANO" apresentado a esse Hospital Universitário, estando vinculado ao Programa Interunidades de Doutoramento em Enfermagem da Escola de Enfermagem da Universidade de São Paulo - EEUSP.

Considerando o parecer favorável apresentado nas instâncias administrativas que envolvem a realização do estudo;

Considerando que o projeto deverá ser analisado pelo Comitê de Ética em Pesquisa da UEL para posterior operacionalização, atendendo a Resolução 466/12 do Conselho Nacional de Saúde;

Informamos que o nosso parecer é favorável à realização do projeto acima nominado, resguardando-se o atendimento da legislação vigente.

Solicitamos que, tão logo o Comitê de Ética emita parecer, essa Diretoria Superintendente seja notificada, para os procedimentos cabíveis relacionados à documentação da pesquisa.

Solicitamos também que, uma vez realizado o estudo, uma cópia seja apresentada a esta Diretoria, para ciência e divulgação.

Em 19/05/2015.

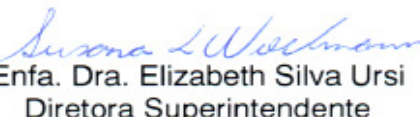

Diretora Superintendente

Comissào de A valiafáo de Projetos de Pesquisa Cientifica (CAPEC) do HU

Fone: (43)3371-2301

e-mail:pesquisahu@uel.br 